\title{
ENVIRONMENTAL IMPACT ASSESSMENT
}

\section{GEOPRESSURE SUBPROGRAM}

July 1977

DIVISION OF GEOTHERMAL ENERGY

ENERGY RESEARCH AND DEVELOPMENT ADMINISTRATION 


\section{DISCLAIMER}

This report was prepared as an account of work sponsored by an agency of the United States Government. Neither the United States Government nor any agency Thereof, nor any of their employees, makes any warranty, express or implied, or assumes any legal liability or responsibility for the accuracy, completeness, or usefulness of any information, apparatus, product, or process disclosed, or represents that its use would not infringe privately owned rights. Reference herein to any specific commercial product, process, or service by trade name, trademark, manufacturer, or otherwise does not necessarily constitute or imply its endorsement, recommendation, or favoring by the United States Government or any agency thereof. The views and opinions of authors expressed herein do not necessarily state or reflect those of the United States Government or any agency thereof. 


\section{DISCLAIMER}

Portions of this document may be illegible in electronic image products. Images are produced from the best available original document. 
EIA/GE/77-3

ENVIRONMENTAL IMPACT ASSESSMENT

GEOPRESSURE SUBPROGRAM

July 1977 

CONTENTS

Page

SUMMARY . . . . . . . . . . . . .

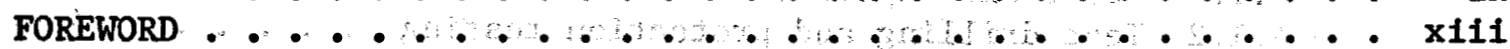

1. PURPOSE OF THE PROPOSED ACTIVITIES . $\ldots, \ldots \ldots$

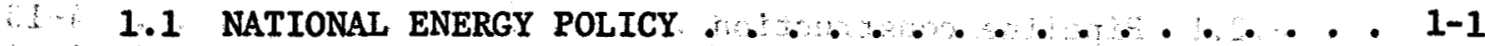

1.2. ERDA GEOTHERMAL PROGRAM . . . . . . . $1-2$

1.2.1. Hydrotherma1 subprogram . . . . . . . . 1-4

1.2.2. Geopressure subprogram • ........... . . . .

1.2.3 Hot dry rock subprogram ............. . . 1-6

1.3 GEOPRESSURED RESOURCE DESCRIPTION

1.4 PROPOSED GEOPRESSURE SUBPROGRAM ACTIVITIES • . . . 1-16

1.4.1. Resource development activities . . . . . . 1-16

1.4.2 - Description of utilization projects . . . . . 1-17

1.4.3 Engineering research and development

. activities . . . . . . . ........ 1-18

1.4.4 Environmental control and institutional

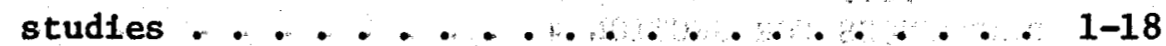

1.4.5 Existing geothermal technology . . . . . . . 1-19

1.4.6. Future development . . . . . . . $1-20$

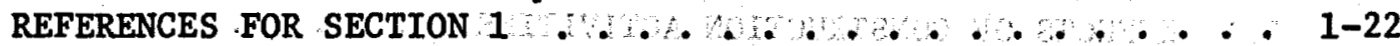

2. ENVIRONS OF POTENTIAL DEVELOPMENT • • • • • • • • 2-1

2.1 GEOLOGY . . . . . . . . . . . . . . . . . . 2-1

2.2 CLIMATOLOGY AND AIR QUALITY = . . . . . . . . 2-14

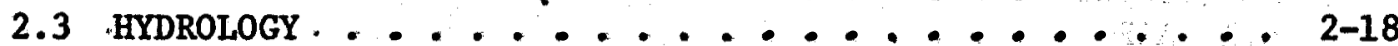

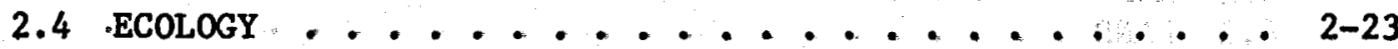

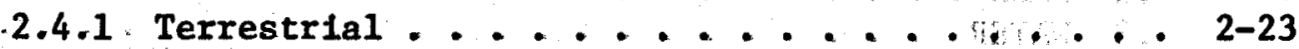

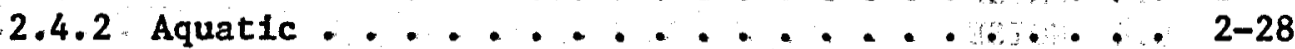

2.4.3. Endangered spectes ......... 2-29

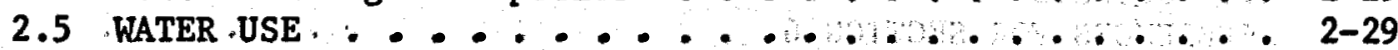

2.6 LAND USE AND REGIONAL DEMOGRAPHY . . . . . . . . 2-32

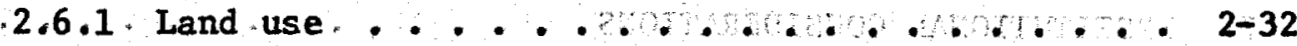

2.6.2 Demography . . . . . . . . . . . 2-34

2.7 REGIONAL HISTORIC, SCENIC, CULTURAL AND

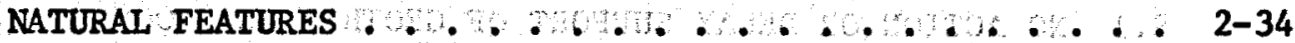

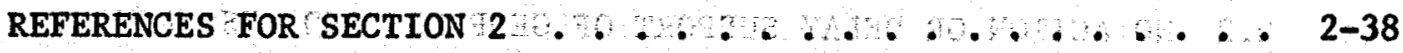

3. DESCRIPTION OF GEOPRESSURE RESOURCE DEVELOPMENT

AND UTILIZATION ..................... 3-1

3.1 RESOURCE DEVELOPMENT . . . . . ..... 3-1

3.1.1 Exploration .................... 3-2

3.1.2 Test drilling and production testing ..... 3-3

3.1.3 Field development........... 3-13

3.2 RESOURCE UTILIZATION ............ 3-15

3.2.1 Electrical production ........... . 3-15

3.2.2 Nonelectrical applications ........ . 3-36

3.3 ENGINEERING RESEARCH AND DEVELOPMENT . . . . . . . . 3-44

REFERENCES FOR SECTION 3............... 3-46 
$\underline{\text { Page }}$

4. ENVIRONMENTAL EFFECTS ................. 4-1

4.1 RESOURCE DEVELOPMENT .............. . 4-3

4.1.1 Reservoir exploration and assessment . . . . . 4-3

4.1.2 Test drilling and protection testing . . . . 4-6

4:1.3 Fleld development ............ 4-12

4.2 RESOURCE UTILIZATION .

4.2.1. Pipeline construction . . . . . . . . .

4.2.2 Site preparation and plant construction $4.4-16$

4.2.3. Transmission line construction ......... . 4-18

4.2.4. Electrical production . . . . . . . 4-19

4.2.5. Nonelectrical applications . . . . . . 4-44

4.2.6. Equipment development . . . . . $4-46$

4.3 ACCIDENTS $\ldots . . . . . . . . . . . . .4-47$

4.3.1 Natural hazards ....................... 48

4.3.2 Earthquake hazards . . . . . . 4-50

4.3.3 Ruptured casing . . ......... 4-53

4.3.4 Blowouts ............. 4-54

4.3.5 Ruptured pipelines and canals . . . . . . 4-59

REFERENCES FOR SECTION $4 . . . . . . . . . . . . . . ~ 4-61$

5. ECONOMIC AND SOCIAL EFFECTS . . . . . . . . . . . . 5-1

5.1 EFFECTS OF CONSTRUCTION ACTIVITIES . . . . . . . . 5-1

5.2 EFFECTS OF OPERATION . . . . . . . . . . . . . . 5-3

REFERENCES FOR SECTION 5.............. 5-4

6. MONITORING ..................... 6-1

6.1 AIR .................... 6-..... 6

6.2 LAND ................... $6-3$

6.3 WATER ...................... 6-4

6.4 NOISE .................. 6-... 6-...

6.5 GEOLOGY ......................... 6-4

REFERENCES FOR SECTION 6 ............. 6-5

7. INSTITUTIONAL CONSIDERATIONS . . . . . . . . . . 7-1

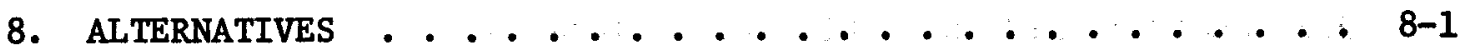

8.1 NO ACTION OR DELAY SUPPORT OF GEOTHERMAL PROGRAM . . . . 8-1

8.2 NO ACTION OR DELAY SUPPORT OF GEOPRESSURED RESOURCES : 8-2 


\section{LIST OF TABLES}

$\underline{\text { Table }}$

$\underline{\text { Page }}$

1.1 Areal extent and average depth, pressure, temperature, and salinity conditions in each subarea . . . . . . . . . . . . . . 1-10

1.2 - Assumed thickness and properties of sand and shale beds in Idealized conceptual reservoirs . . . . . 1-11

1.3 Calculation of geothermal potential in W11cox

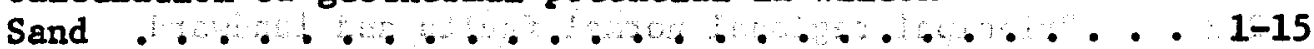

2.1 Estimated annual concentration ranges of suspended particulates (1961-1965) . . . . . . . . . 2-17

2.2 Estimated annual emissions and concentrations of sulfur dloxide $\left(\mathrm{SO}_{2}\right)(1961-1965), \ldots . . . . . . .2-17$

2.3 Air dispersion characteristics for geopressure

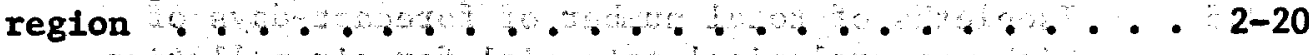

2.4 Conservation storage data for selected reservoirs of the Texas coastal margin .............. 2-20

2.5 Water quality data for selected surface-water systems of coastal Texas and Louisiana ... . . . . 2-22

2.6 Threatened wildiffe whose range is expected to - extend within the Gulf of Mexico geopressured region ................... 2- 2- 30

2.7 Land use summary for representative counties . . . 2-33

2.8 Population densities for representative counties

$8 I \ldots \ldots$ (parlshes) within the geopressure zone ....... 2-36

3.1 Geopressured Manchester Field compared with normal pressured Hackberry Fleld . . . . . . . . . 3-28

3.2 Potential Industrial applications of geopressured resources on the Gulf Coast ............ . . . . . .

4.1 Comparison of noise levels between The Geysers (California) hydrothermal resource data and other

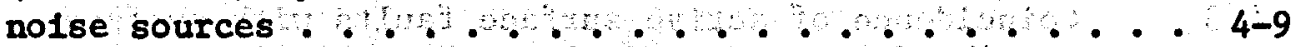

4.2 Potential reservoir compaction in Armstrong field ... . 4-28

4.3 Potential land subsidence over Armstrong fleld . . . 4-28 
LIST OF FIGURES

Elgure

Page

1.1 Areas of potential geopressure resources in the United States ............... 1- . . . .

1.2 Location map showing the extent of the assessed geopressured zones and their division into subareas . . 1-9

2.1 World map of deep Tertlary clastic basins ....... 2-2

2:2 Principal regional normal faults and landward boundary of Miocene deposits - northern Gulf of Mexico Basin . . . . . . . . . 2-4

2.3 Tertiary formations - Gulf coast of Texas . . . . . 2-7

2.4 Types of reservoir seals necessary to preserve abnormal pressure . . . . . . . . . . . . 2-12

2.5 Isopleths of total number of forecast-days of high meteorological potential for alr pollution

in a five-year period .................. 2-19

2.6 Productive aquifers of the Texas - Loulsiana coastal reglons.................. 2-24

2.7 Population distribution in Louisiana and Texas . . . 2-35

2.8 Historic sites and landmarks and natural landmarks . . 2-37

3.1 Diagram of typical drilling arrangement in geothermal development . . . . . . . . . . 3-8

3.2 Methods for recovery of energy from geopressured systems . . . . . . . . . . . . . . . 3-18

4.1 Relationship between porosity and depth of burial for varlous values of $\lambda$ (fluid pressure-overburden pressure ratio) for an average shale or mudstone ... . 4-27

4.2 Comparison of rates of subsidence to ofl and natural gas production from Chocolate Bayou 011 field between the years 1942 and $1973 \ldots . . . . . . . .4-33$

4.3 Coincidence of active surface faults with surface traces of subsurface faults, Houston-Galveston area . . . 4-35

4.4 Fault-controlled land subsidence for the Saxet and Chocolate Bayou 011 and Gas fields . . . . . . . 4-36 
4.5 Probability (percentage) that a hurricane (winds exceeding $73 \mathrm{mph}$ ) or great hurricane (winds exceeding $125 \mathrm{mph}$ ) w111 occur in any one year in a 50-mile segment of the coastline ........ 4-49

4.6 Selsmic risk map of the United States . . . . . . 4-51

4.7 Earthquake frequency as a function of Injection rate and wellhead pressure for a disposal well at Rocky Mountain Arsenal ... . . . . . . . . 4-52

4.8 Pressure conditions, southern Louisiana . . . . . . . 4-56 

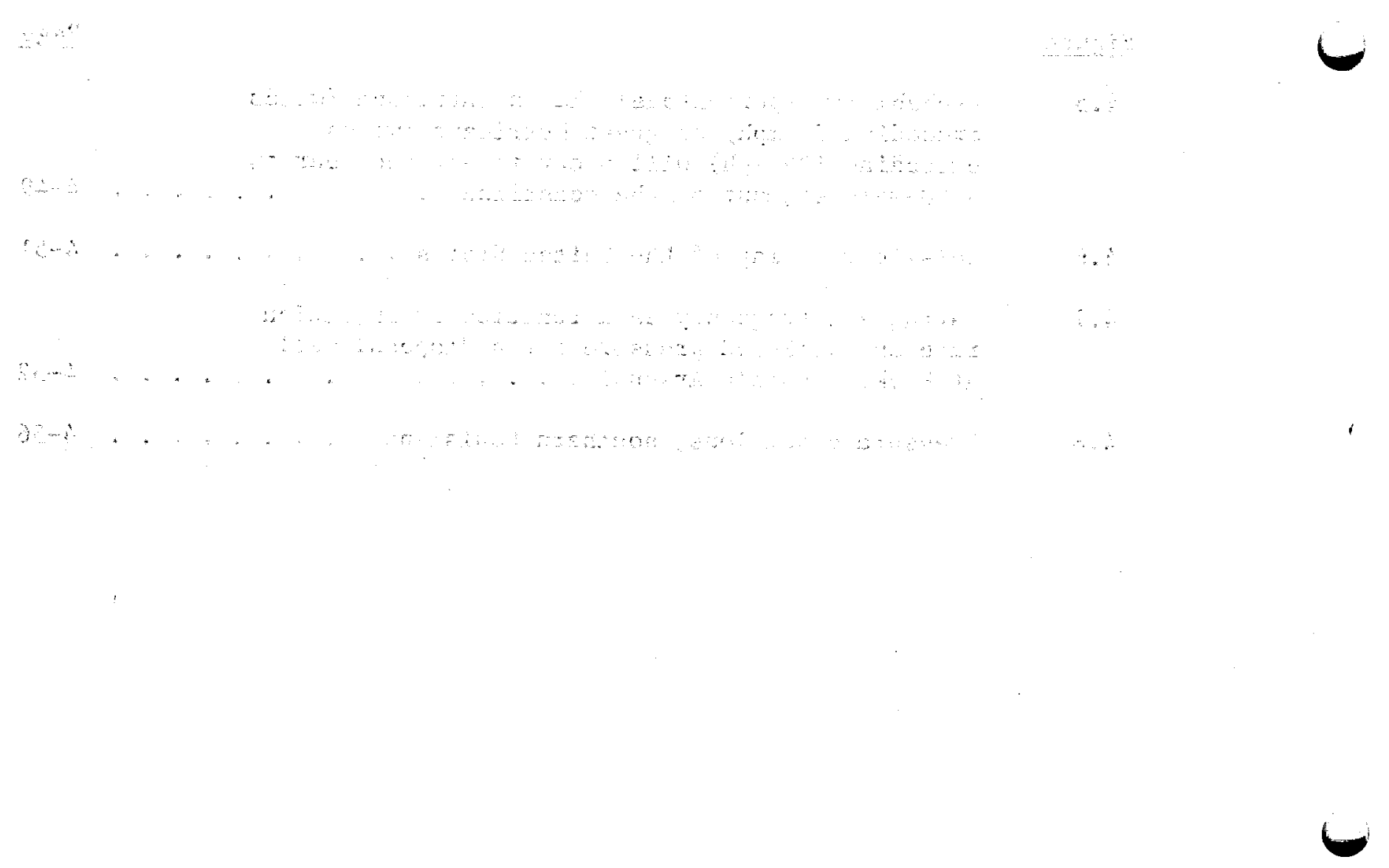

6 
SUMMARY

This environmental Impact assessment (EIA) addresses the expected programmatic activities of the Geopressure Subprogram of the Division of Geothermal Energy. The goal of the Geopressure Subprogram is to stimulate development of geopressured resources as an economic, rellable, operationally safe, and environmentally acceptable energy source. The subprogram includes activities in the areas of engineering research and development; resource exploration, assessment, and development; resource utilization including pilot and demonstration facilities; and environmental research and control technology development. It should be recognized that most of the subprogram activities extend over several years and are in their early stages of implementation at this time.

The zones of potential geopressure development are in the region located along the Texas and Loulstana Gulf Coasts extending up to 200 miles $(300 \mathrm{~km})$ Inland. Geopressured zones are sedimentary basins where water is trapped at high pressures within or below thick, nearly Impermeable shale sequences. The confined water supports most or all of the weight of the overburden. This inhibits sediment compaction and causes formation pore pressure to exceed hydrostatic pressure. In sedimentary basins that are underlain by thin oceanic crust, upward thermal conduction from the mantle heats geopressured fluids and sediments to abnormally high temperatures, often in excess of $260^{\circ} \mathrm{C}\left(500^{\circ} \mathrm{F}\right)$. 
The fluid resource base is the potential recoverable energy within the geopressured zones. It consists of three major forms: water at high temperatures, water at high pressures, and dissolved natural gas.

its tit

Geopressure regions lie within the warm-temperate, subtropical zone that supports a mild climate. Average temperatures decline northward from $24^{\circ} \mathrm{C}\left(75^{\circ} \mathrm{F}\right)$ at the mouth of the Rio Grande to $20^{\circ} \mathrm{C}\left(68^{\circ} \mathrm{F}\right)$ along southern Louisiana. Humidity is high $(60-80 \%)$ in sumer. Annual average precipitation Increases northward along the Gulf Coast from $59 \mathrm{~cm}$ (20 in.) to $150 \mathrm{~cm}(60 \mathrm{in.})$ on the Texas-Louislana border and $163 \mathrm{~cm}(64 \mathrm{in.})$ along the Louisiana coast. Tropical cyclones commonly reach coastal areas. Air quality is generally excellent.

Surface water flow patterns are generally toward the Gulf of Mexico. Major surface water channels include the Misslssippi and Calcasleu rivers In Louisiana and the Rio Grande, Nueces, San Antonio, Colorado, Brazos, Trinfty, and Sabine rivers in Texas. Dams control discharge.

Four distinct habitat types are seen in coastal Texas and Louisiana: barrier Islands, tidal marshlands, river bottoms, and uplands.

Principal land uses in the geopressured regions are agriculture, petroleum and natural gas production, and unused marshland. Relatively little land is Federally owned. Cotton and beef production are principal agricultural products. 
Population densities range from sparse to dense in the region. Most development may be expected to occur away from major population centers.

Potential environmental Impacts may result from a variety of programmatic activities and will vary in importance in different areas. In general, the adverse effects of geopressure exploration, construction, and operation activities can be minimized to acceptable levels with proper planning and the application of appropriate control technology.

Potential environmental effects of resource exploration and development Include noise, contamination of water bodies with drilling muds, groundwater contamination, siltation, erosion, and the noxious effects of released gases and aerosols.

Construction of utilization facilities, pipelines, and transmission Iines will have Impacts similar to any large construction activity.

Potential environmental effects of operation of utilization facilities may be caused by noncondensable gas release, noise, geothermal fluid disposal, and cooling tower discharge. In addition, subsidence may result from withdrawal of large volumes of geothermal fluids; this would affect urban areas or near-shore ecological communities.

Socletal effects are not great and can be mitigated with proper planning and community involvement in decision making. 
The alternatives addressed Include no action and delayed action of both the National Geothermal RD\&D Program and the Geopressure Subprogram.

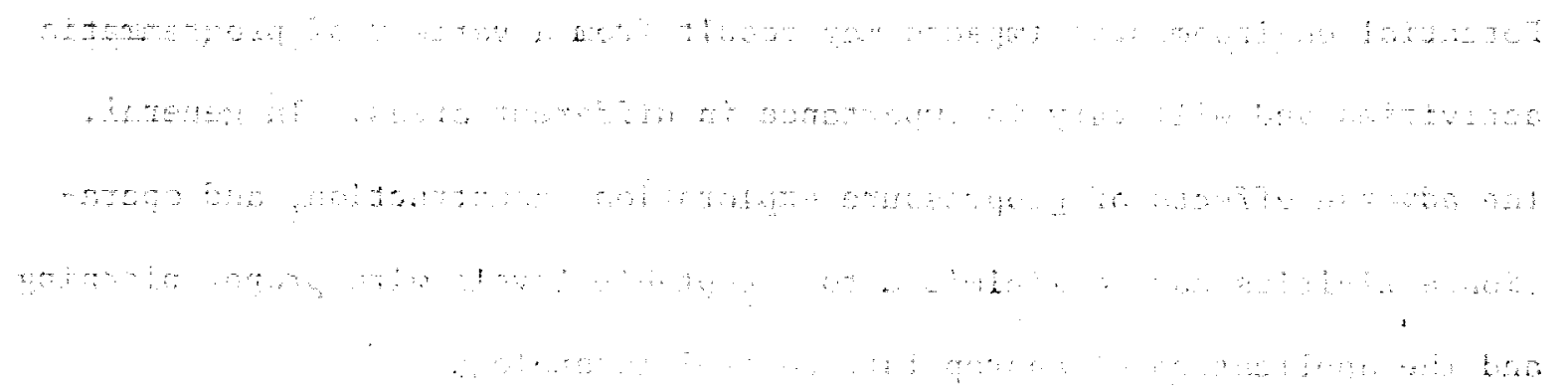




\section{FOREWORD}

This environmental impact assessment (EIA) has been prepared in compliance with the requirements of Title 10, Part 711 , of the Code of Federal Regulations, which prescribes the procedures to be followed by the Energy Research and Development Administration (ERDA) for Implementation of the National Environmental Policy Act of 1969. The assessment addresses the expected programatic activities of the Geopressure Subprogram of the ERDA Division of Geothermal Energy (DGE). The Geopressure Subprogram is one of several subprograms developed and implemented by ERDA for fulfilling Its legislative mandate to pursue a National Geothermal Energy Research, Development and Demonstration Program.

This EIA is based on information avallable as of January 1, 1977. A1though specific sites and designs are not avallable due to the programmatic scope of this assessment, the information presented here provides a sufficient basis for evaluation of potential environmental impacts resulting from subprogram implementation.

The EIA is divided into eight parts. Part 1 provides general background and the purpose of the Geopressure Subprogram; Part 2 characterizes the existing environments in regions expected to experience programmatic activities; Part 3 describes programmatic activities; Parts 4 and 5 address the potential environmental, economic, and social effects of programmatic activities on the existing environments; Parts 6 and 7 deal with monitoring and institutional considerations; and Part 8 addresses alternatives. 


\section{PURPOSE OF THE PROPOSED ACTIVITIES}

Environmental assessments of significant programatic activities and Individual projects of the Division of Geothermal Energy (DGE) of the Energy Research and Development Administration (ERDA) are being prepared In accordance with the requirements of 10 CFR Part 711. Th1s environmental assessment of the geopressure subprogram addresses the expected programmatic activities, affected environments, and possible impacts on a regional basis. Individual site-specific environmental assessments w111 be prepared at appropriate later dates for DGE-supported projects. having potentlal environmental impacts. This document identifles areas of potential Impact on the human environment that could result from the combined or Individual projects of the geopressure subprogram and from the resultant industry assoclated with the technology demonstrated.

\subsection{NATIONAL ENERGY POLICY}

The National Plan for Energy Research and Development ${ }^{1}$ was formulated to explore a wide range of energy options to meet this country's growing energy needs. The basic objectives are to decrease our dependence on the relatively limited supplies of natural gas and ofl; to increase use of the more abundant (or less used) supplies of coal, urantum, solar, geothermal, and fusion energies; and to reduce energy demand through conservation.

Present estimates Indicate that petroleum production in the United States cannot meet national demands beyond 1990. Thus, long-range planning, 
equipment and process development and demonstration, and financlal assistance for commercialization are necessary if adequate domestic energy alternatives are to be available to meet national needs in the latter part of this century.

To ensure that geothermal energy can supply a reasonable percentage of this country's energy needs, Congress has enacted the Geothermal Energy Research, Development and Demonstration Act of 1974.2 This act calls on the Federal Government to encourage and essist private Industry in the development and demonstration of practicable means of producing energy from geothermal resources in an environmentally sound manner. This assistance is to include resource assessment, research and development profects, education, and direct financial assistance to private industry.

\subsection{ERDA GEOTHERMAL PROGRAM}

ERDA was mandated by Its organizing legislation to pursue the major portion of a National Geothermal Energy RD\&D Program. ${ }^{3}$ The goal of this program is to work with industry to provide the nation with an acceptable option for timely exploitation of geothermal resources in the United States. 4 To meet this goal, ERDA has developed a strategy for a diverse approach which includes (1) reducing uncertainties in resource assessment ard (2) assisting industry to rapidly develop the natural geothermal resources and extend the usable geothermal resource base through advanced technology. 
The specific parts of the program addressed by this environmental assessment are included in the geopressure subprogram. In all, there are three subprograms to be addressed by three environmental assessments: hydrothermal, geopressure, and hot dry rock. A fourth subprogram, equipment development, will be divided among the three assessments, depending on which resource type the equipment development will support.

The subprogram names are based on the distinct type of geothermal energy addressed by each. The hydrothermal subprogram deals with geothermal resources in which water at elevated temperature or steam is naturally present near the earth's surface. The geopressure subprogram is concerned with a specific type of hydrothermal resource in which the fluid pressure is much higher than is ordinarily encountered. The hot dry rock subprogram includes geothermal resources comprised of nonmolten rocks of a higher than normal temperature not associated with the presence of water. Two additional forms of geothermal resources are recognized, 5 but they are not singled out as specific subprograms at this time. They are the magmatic (molten rock) heat source and the normal gradient heat source, which consists of rocks having a temperature gradient lower than the hot dry rock resource.

The goal of each subprogram is to encourage the development of a viable Industry to explott the geothermal resource by providing assistance in the technological, legal, Institutional, and environmental aspects of geothermal utilization. 


\subsubsection{Hydrotherma1 subprogram}

The hydrothermal resource includes both steam- and 11quid-dominated geothermal reservoirs. Of all the geothermal resources, the hydrothermal resource, as a class, will probably make the most significant contribution to the national energy supply in the near future. A substantial amount of development has occurred at the steam-dominated reservoirs of The Geysers north of San Francisco, but all Indications show that steamdominated reservoirs are rare anomalies and may exist only at The Geysers in economically recoverable quantities. A total of $502 \mathrm{MW}$ of electrical capacity is now operating at The Geysers, with plans to install an additional $400 \mathrm{MW}(\mathrm{e})$ within the next few years. A total of only 16 MN of nonelectrical capacity has been developed for all of the liquid-dominated hydrothermal regions in the United States. Because of the energy potential of the 1iquid-dominated resource, the ERDA hydrothermal subprogram emphasizes support of this resource over the vapor-dominated resource. However, some support of vapor-dominated hydrothermal development is provided at this time by other ERDA programs, including environmental research programs and the geothermal loan guarantee program.

The specific objectives of the hydrothermal subprogram are to (1) determine the technical feasibility of using liquid-dominated geothermal resources for both electrical power generation and nonelectrical application of geothermal heat and (2) support research and development activities in this area. The subprogram development effort will systematically progress from the testing of components and subsystems under field conditions to 
reservolr exploration and assessment, fleld development, and scaled testing of integrated energy conversion systems in pilot or demonstration plants to determine the technical and economic viability of a complete geothermal utilization system.

The environmental impact assessment of the hydrothermal subprogram is contalned in a separate document identified as EIA/GE/77-2, which is avallable for public inspection in public document rooms located at ERDA Headquarters and ERDA Operations offices.

\subsubsection{Geopressure subprogram}

The geopressure resource Includes water at high temperatures and hIgh pressures trapped within basin sediments along the Texas-Louisiana Gulf Coast. The water is confined within or below essentially impermeable shale sequences and carries most or all of the overburden pressure. Such zones are referred to as "geopressured strata." These fluids and sediments are heated to higher than normal temperatures for depths at which geopressured formations occur (up to $260^{\circ} \mathrm{C}$ ) and may provide potential reservolus for economlcal production of geothermal energy.

Currently, Industrial Interest in geopressure energy development is IImited because it is a regional resource without development experience. Thus, the ERDA geopressure subprogram will include stimulation of interest at all stages of development - from evaluation of the state of knowledge regarding reservolrs through support for the construction and operation of pilot and demonstration plants. 


\subsubsection{Hot dry rock subprogram}

The hot dry rock resource consists of rocks having a high thermal gradient, but having no fluid naturally present. There is a substantially greater amount of heat energy contained in hot rocks than in geothermal fluid reservoirs, and a large portion of these rocks is within reach of present drilling technology. ERDA is supporting the development of methods for extracting the heat from hot dry rocks. A likely method is that of driling two holes and fracturing the rock between them to allow a fluid to be circulated through the rock. The heated fluid would then be used as a heat source in a manner similar to natural geothermal fluids.

The goal of the ERDA hot dry rock subprogram is the development and demonstration of the technology to extract and use the energy of different types of hot dry rocks. The pursuit of this goal w111 include resource assessment, development of energy extraction techniques, and development of systems for using the resource in an environmentally acceptable manner.

The ERDA hot dry rock subprogram w111 include all aspects of development support - from the rock characterization and resource reconnalssance stage through construction and operation of pilot and demonstration plants.

The environmental assessment of the hot dry rock subprogram will be published separately. 


\subsection{GEOPRESSURED RESOURCE DESCRIPTION}

Geopressured zones are sedimentary basins where water is trapped at high pressures within thick, nearly impermeable shale sequences. The confined water supports most or all of the weight of the overburden. This inhibits sediment compaction and causes formation pore pressure to exceed hydrostatic pressure. It is theorized that in sedimentary basins that are underlain by thin oceanic crust, upward thermal conduction from the mantle heats geopressured fluids and sediments to higher than normal temperatures, as much as $260^{\circ} \mathrm{C}\left(500^{\circ} \mathrm{F}\right)$ in very deep formations. 6

Within the United States, numerous geopressured zones are located in the northern Gulf of Mexico basin (see Fig. 1.1). The most easily accessible zones 11e within Tertiary sediments beneath an area $145,000 \mathrm{~km}^{2}$ along a narrow belt extending from the Rlo Grande in Texas, northeast to the Pearl River in Louisiana, and Inland from the Gulf shoreline. 7 These sediments are comprised of interfingering beds of sand and shale. The U:S. Geological Survey has divided the area into surface subareas, based on geological environments. For location and characteristics of these zones, see FIg. 1.2 and Tables 1.1 and 1.2 . Other geopressured areas, though not currently accessible, are located in: (1) Tertiary sediments extending offohore to the continental shelf $\left(133,000 \mathrm{~km}^{2}\right)$, (2) Tertiary sediments onshore but below the present depth well control ( 6 to $7 \mathrm{~km}$ ), and (3) Cretaceous sediments underlying the Tertiary beds and extending farther Inland (an additional $52,000 \mathrm{~km}^{2}$ ).7 The current ERDA subprogram does not address offshore resources; therefore this assessment is confined to the envirommental impacts of onshore development. 


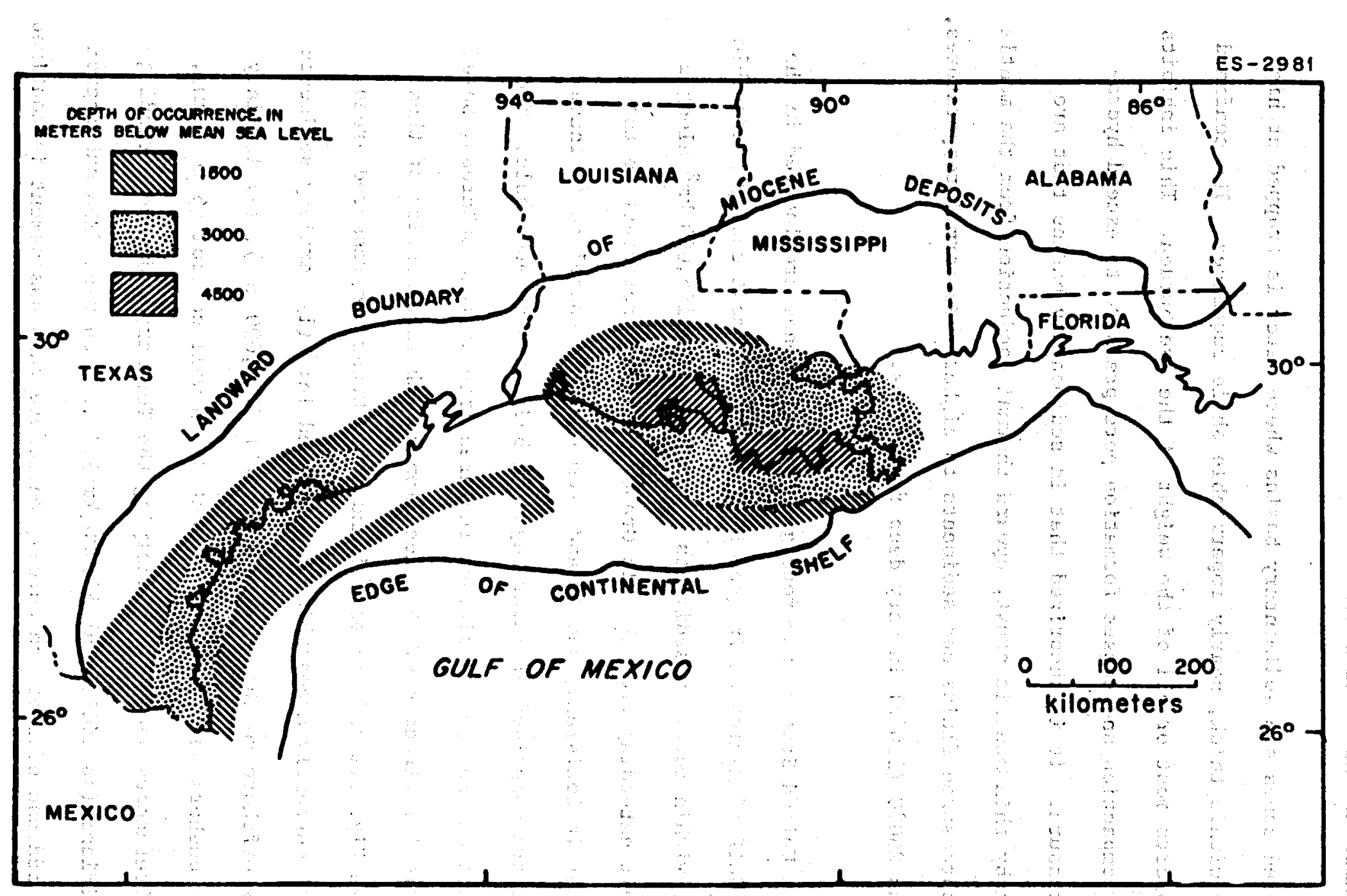

Fig. 1.1. Areas of potential geopressure resources in the United States. Source: M. H. Dorfman and R. W. Deller, Proceedings of the Second Geopressured Geothermal Energy Conference, Volume I: Summary. and Future Projections, University of Texas; Austin, February 1976. 




Fig. 1.2. Location map showing the extent of the assessed geopressured zones and their division into subareas (AT, BT, etc.). Source: S. S. Papadopulas, R. H. Wallace, Jr., J. B. Wesselman, and R. E. Taylor, "Assessment of Onshore Geopressured-Geothermal Resources in the Northern Gulf of Mexico Basin," Geological Sumey Circular 726, 1975. 
Table 1.1. Areal extent and average depth, pressure, temperature, and salinity conditions in each subarea

\begin{tabular}{|c|c|c|c|c|c|c|c|}
\hline \multirow[t]{2}{*}{ Subarea } & \multirow{2}{*}{$\begin{array}{r}\text { Areal } \\
\text { extent } \\
\left(\mathrm{km}^{2}\right)\end{array}$} & \multirow{2}{*}{$\begin{array}{l}\text { Average } \\
\text { depth } \\
\text { to top of } \\
\text { geopressure } \\
(\mathrm{km})\end{array}$} & \multirow{2}{*}{$\begin{array}{l}\text { Average } \\
\text { depth } \\
\text { to } \\
\text { midpoint } \\
\text { (km) }\end{array}$} & \multirow{2}{*}{$\begin{array}{l}\text { Average } \\
\text { pressure } \\
\text { (meganewtons } / \mathrm{m}^{2} \text { ) }\end{array}$} & \multirow{2}{*}{$\begin{array}{l}\text { Average } \\
\text { temperature } \\
\left({ }^{\circ} \mathrm{C}\right)\end{array}$} & \multicolumn{2}{|c|}{$\begin{array}{l}\text { Average } \\
\text { salinity }\end{array}$} \\
\hline & & & & & & $\begin{array}{l}\text { Number of } \\
\text { samples }\end{array}$ & $\begin{array}{c}\text { TDS } \\
\text { (g/liter) }\end{array}$ \\
\hline $\mathrm{AT}_{1}$ & 8,948 & 2.36 & 4.18 & 82.4 & 186 & & $16^{a}$ \\
\hline $\mathrm{ATL}_{2}$ & 20,965 & 2.47 & 4.23 & 78.5 & 156 & & $20^{a}$ \\
\hline $\mathrm{BT}_{1}$ & 13,588 & 1.82 & 3.91 & 74.6 & 170 & 362 & 30 \\
\hline $\mathrm{BT}_{2}$ & 5,595 & 2.32 & 4.16 & 81.4 & 150 & 50 & 38 \\
\hline $\mathrm{CT}_{1}$ & 8,230 & 2.47 & 4.23 & 81.4 & 172 & 20 & $24^{b}$ \\
\hline DT 1 & 4,861 & 2.92 & 4.46 & 88.3 & 172 & 95 & 23 \\
\hline $\mathrm{DT}_{2}$ & 5,155 & 2.68 & 4.34 & 86.3 & 169 & 2 & 33 \\
\hline $\mathrm{DT}_{3}$ & 7,425 & 2.41 & 4.20 & 80.4 & 153 & 67 & 28 \\
\hline $\mathrm{DTL}_{4}$ & 5,102 & 2.62 & 4.31 & 83.4 & 141 & 18 & 46 \\
\hline $\begin{array}{l}D L_{5} \\
D L_{6}\end{array}$ & $\begin{array}{l}7,015 \\
3,729\end{array}$ & $\begin{array}{l}3.01 \\
3.05\end{array}$ & $\begin{array}{l}5.01 \\
5.02\end{array}$ & $\begin{array}{l}102.0 \\
104.0\end{array}$ & $\begin{array}{l}164 \\
160\end{array}$ & $\begin{array}{c}222 \\
14\end{array}$ & $\begin{array}{l}65^{c} \\
55^{d}\end{array}$ \\
\hline $\mathrm{ET}_{1}$ & 5,400 & 2.96 & 4.48 & 83.4 & 168 & 34 & $34^{b}$ \\
\hline $\mathrm{ET}_{2}$ & 1,938 & 2.63 & 4.32 & 83.4 & 166 & 24 & 17 \\
\hline $\mathrm{ET}_{3}$ & 7,496 & 2.37 & 4.19 & 80.4 & 146 & 65 & 27 \\
\hline $\mathrm{ETL}_{4}$ & 3,461 & 2.63 & 4.31 & 87.3 & 140 & 14 & 52 \\
\hline$E L_{5}$ & 8,144 & 3.66 & 5.33 & 106.9 & 165 & 39 & $90^{\circ}$ \\
\hline$E L_{6}$ & 8,849 & 3.32 & 5.16 & 105.0 & 159 & 87 & 83 \\
\hline $\mathrm{EL}_{7}$ & 6,249 & 2.99 & 5.00 & औ 100.1 & 146 & 9 & 26 \\
\hline $\mathrm{FT}_{1}$ & 2,269 & 3.11 & 4.55 & 86.3 & $171 \ldots$ & 5 & $15^{b}$ \\
\hline $\mathrm{FT}_{2}$ & 4,707 & 3.76 & 5.38 & 105.0 & 148 & 46 & $84^{d}$ \\
\hline $\mathrm{FL}_{\mathbf{3}}$ & 6,139 & 3.88 & 5.44 & 110.8 & 151 & 11 & $45^{d}$ \\
\hline Total & 145,265 & & & & & 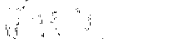 & \\
\hline
\end{tabular}

Estimated; samples not available.

${ }^{b}$ Salinity as $\mathrm{NaCl}$ calculated from spontaneous potential of well logs; number of samples refers to number of well logs.

conly a few samples from deep zones are included.

No samples from deep zones are included.

Source: S. S: Papadopulas, R. H. Wallace, Jr., J. B. Wesselman, and R. E. Taylor, "Assessment of Onshore Geopressured-Geothermal Resources in the Northern Gulf of Mexico Basin," Geological Survey Circular 726, 1975. 
Table 1.2. Assumed thickness and properties of sand and shale beds in idealized conceptual reservoirs

\begin{tabular}{|c|c|c|c|c|c|c|c|c|c|c|c|c|c|c|c|c|c|}
\hline \multirow{2}{*}{ Reservoir } & \multirow{2}{*}{8} & \multirow{2}{*}{$\begin{array}{l}\text { Total } \\
\text { reservoir } \\
\text { thickness } \\
(\mathrm{km})\end{array}$} & \multirow{2}{*}{$\frac{1}{2}$} & 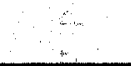 & $\vdots$ & \multicolumn{4}{|c|}{ Sand aquifer } & \multirow{2}{*}{$\begin{array}{l}\text { Average } \\
\text { porosity } \\
(\%)\end{array}$} & \multicolumn{5}{|c|}{ Upper shale bed } & \multicolumn{2}{|c|}{ Lower shale bed } \\
\hline & & & & $\begin{array}{c}\text { Jumber of } \\
\text { wells }\end{array}$ & 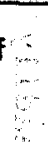 & $\begin{array}{c}\text { Extrapolated } \\
\text { thickness } \\
\text { (km) }\end{array}$ & $\begin{array}{c}3 \\
\vdots \\
\vdots \\
\vdots\end{array}$ & $\begin{array}{r}\text { A } \\
\text { pern } \\
(\mu \text { dar }\end{array}$ & $\begin{array}{l}\text { verage } \\
\text { neability } \\
\text { rcies, md) }\end{array}$ & & & $\begin{array}{l}\text { hssumed } \\
\text { hickness } \\
(\mathrm{km})\end{array}$ & 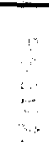 & $\begin{array}{c}\text { Assumed } \\
\text { porosity } \\
\text { (\%) }\end{array}$ & 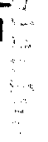 & $\begin{array}{c}\text { Assumed } \\
\text { thickness } \\
(\mathrm{km})\end{array}$ & $\begin{array}{c}\text { Assumed } \\
\text { porosity } \\
\text { (\%) }\end{array}$ \\
\hline $\mathrm{AT}_{1}$ & 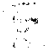 & 3.64 & 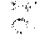 & 13 & & 0.63 & 4 & 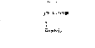 & 20 & 18 & $\because$ & 1.80 & 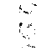 & 16 & & 1.21 & 12 \\
\hline ATL $_{1}$ & 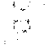 & 3.53 & 3 & 33 & 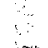 & 0.91 & & 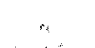 & 35 & 21 & $\cdots$ & 1.40 & & 17 & $\ldots$ & 1.22 & 11 \\
\hline $\mathrm{BT}_{1}$ & 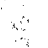 & 4.18 & $\therefore$ & 9 & 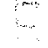 & 0.56 & 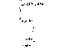 & ? & 15 & 18 & & 1.89 & 8 & 18 & $\therefore$ & 1.73 & 12 \\
\hline $\mathrm{BT}_{2}$ & 8 & 3.68 & 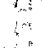 & 6 & $\therefore$ & 0.55 & 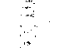 & 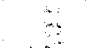 & 20 & 20 & 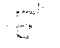 & 1.82 & . & 17 & & 1.31 & 11 \\
\hline $\mathrm{CT}_{1}$ & $\therefore$ & 3.53 & 8 & 5 & 3 & $\therefore 1.14$ & 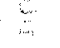 & 3 & 20 & $\therefore 19$ & $\because$ & 1.37 & $\therefore$ & 17 & 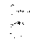 & .01 & 11 \\
\hline $\mathrm{DT}_{1}$ & 3 & 3.08 & $\therefore$ & 9 & 6 & 1.22 & $\because$ & 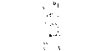 & 25 & 19 & 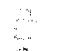 & 1.19 & .' & 16 & $\therefore$ & 0.67 & 11 \\
\hline $\mathrm{DT}_{2}$ & 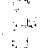 & 3.32 & & 4 & $\Rightarrow$ & 0.54 & 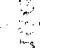 & & 20 & 20 & $\cdots$ & 1.74 & - & 16 & $\approx$ & 1.04 & 11 \\
\hline $\mathrm{DT}_{3}$ & 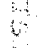 & 3.59 & 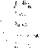 & 7 & 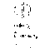 & $\mathbf{0 . 5 5}$ & 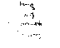 & 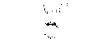 & 25 & .20 & & 1.71 & 3 & 16 & 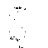 & 1.33 & 12 \\
\hline $\mathrm{DTL}_{4}$ & 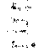 & 3.38 & & 8 & 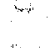 & 0.41 & & 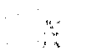 & 30 & 21 & $\because$ & 1.75 & $\because$ & 16 & $\therefore$ & 1.22 & 11 \\
\hline $\mathrm{DL}_{5}$ & $\cdots$ & 3.99 & 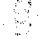 & 15 & 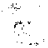 & 0.56 & $\because$ & 3 & 25 & 20 & $\cdots$ & 2.22 & & 14 & & 1.21 & 10 \\
\hline$D L_{6}$ & 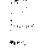 & 3.95 & 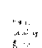 & 4 & 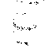 & 0.76 & 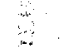 & $\because$ & 25 & $20^{3}$ & 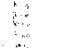 & 2.14 & 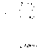 & 14 & 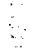 & 1.05 & 10 \\
\hline$E T_{1}$ & 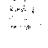 & 3.04 & 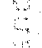 & 4 & 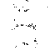 & $1.50^{\circ}$ & 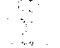 & 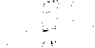 & 20 & 19 & 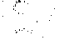 & 0.88 & 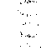 & 16 & 3 & 0.66 & 11 \\
\hline$E T_{2}$ & 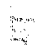 & 3.37 & & 4 & $\therefore$ & 0.61 & 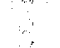 & 3 & 30 & 20 & $\because$ & 1.63 & $\therefore$ & 16 & $\therefore$ & 1.13 & 11 \\
\hline $\mathrm{ET}_{3}$ & & 3.63 & 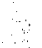 & 12 & 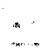 & 0.74 & 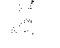 & 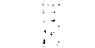 & 35 & 21 & $\vdots$ & 1.63 & & 17 & 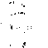 & 1.26 & 11 \\
\hline $\mathrm{ETL}_{4}$ & 3 & 3.37 & 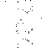 & 9 & $\cdots$ & 0.42 & - & & 30 & 21 & $\cdots$ & 1.90 & $y$ & 16 & 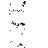 & 1.05 & 11 \\
\hline$E L_{5}$ & 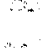 & 3.34 & 3 & 13 & 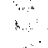 & 0.67 & 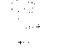 & 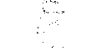 & 40 & 21 & 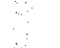 & 1.78 & 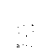 & 13 & 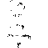 & 0.89 & 10 \\
\hline $\mathrm{EL}_{6}$ & 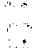 & 3.68 & $=$ & 12 & 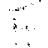 & 0.75 & $\therefore$ & $\cdots$ & 40 & $\therefore \quad 21$ & & 1.95 & 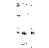 & 14 & 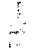 & 0.98 & 10 \\
\hline $\mathrm{EL}_{7}$ & p. & 4.01 & 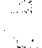 & 7 & $\therefore$ & 1.02 & $\because \cdots$ & 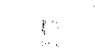 & 40 & 21 & 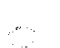 & 1.87 & 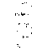 & 15 & 3 & 1.12 & 9 \\
\hline $\mathrm{FT}_{1}$ & $\cdots$ & 2.89 & $\therefore$ & 4 & 6 & 0.93 & 3 & 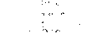 & 25 & 20 & $\because$ & 1.18 & & 15 & $\vdots$ & 0.78 & 11 \\
\hline$F_{2}$ & 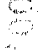 & 3.24 & & 6 & & 0.90 & 3 & & 50 & 22 & 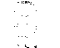 & 1.49 & $\because$ & 13 & - & 0.85 & 10 \\
\hline $\mathrm{FL}_{3}$ & $\because$ & 3.12 & $\because$ & 9 & $\cdots$ & 0.66 & $\ldots$ & " & 40 & 22 & $\therefore$ & 1.73 & $\ldots$ & 13 & $\because$ & 0.73 & 9 \\
\hline
\end{tabular}

Source: S. S. Papadopulas, R. H. Wallace, Jr., J. B. Wesselman, and R. E. Taylor, "Assessment of Onshore Geopressured-Geothermal Resources in the Northern Gulf of Mexico Basin," Geological Survey Circular 726, 1975. 
The geopressured fluld resource base contains energy in three major forms: water at high temperature, water at high pressure, and dissolved natural gas.

Much of the heat conducted upward from the mantle is absorbed by the undercompacted water-bearing zones because of their insulating properties. Temperatures of 107 to $149^{\circ} \mathrm{C}\left(225\right.$ to $300^{\circ} \mathrm{F}$ ) occur at depths of $3,000 \mathrm{~m}$ $(10,000 \mathrm{ft})$; at depths of $4,500 \mathrm{~m}(15,000 \mathrm{ft})$, temperatures in excess of $177^{\circ} \mathrm{C}\left(350^{\circ} \mathrm{F}\right)$ are often found, Within the basin, temperatures greater than $260^{\circ} \mathrm{C}\left(500^{\circ} \mathrm{F}\right)$ have been found at depths of $6,000 \mathrm{~m}(20,000 \mathrm{ft}) .^{8}$ These temperatures represent significant thermal energy for conversion to electricity, industrial and agricultural process heat, and/or space heat energy.

In addition to the high temperatures of the water, these fluids also exist at abnormally high pressures. Under normal conditions, interstitial waters exist at about $0.0106 \mathrm{MN} / \mathrm{m}^{3}(0.465 \mathrm{ps} 1 / \mathrm{ft})$ or hydrostatic pressure. However, the geopressured waters often approach lithostatic pressure $\left[0.0227 \mathrm{MN} / \mathrm{m}^{3}(1 \mathrm{psi} / \mathrm{ft})\right]$. Fluids, therefore, flow readily into well bores and to the surface where potential hydraulic energy can be converted for useful purposes, such as the generation of electricity. The change from hydrostatic to lithostatic pressure is usually characterized by an abrupt interface encountered at depths from 1,500 to $4,500 \mathrm{~m}$ $(5,000$ to $15,000 \mathrm{ft})$; beyond this interface, the sediments exhibit increasingly abnormal pressure with depth. ${ }^{8}$ 
The shales that 1le within the geopressured zones are thought to be the source beds for most or all the hydrocarbons within the Cenozolc portion of the Gulf of Mexico basin.8 Natural gas, easily soluble in water, is apparently available within these formation fluids. Up to $100 \mathrm{ft}^{3}$ $\left(2.83 \mathrm{~m}^{3}\right)$ of natural gas per barrel of water may be dissolved under the high pressure-high temperature reservoir conditions. 7 Methane comprises most of the dissolved gas; ethane and propane are present in minute quantities. Only minimal concentrations of heavier hydrocarbons are found. Tested dry-gas reservolrs in the geopressured zones indicated no evidence of hydrogen sulfide $\left(\mathrm{H}_{2} \mathrm{~S}\right)$ or other serious contaminants, but small amounts of $\mathrm{H}_{2} \mathrm{~S}$ may be present In the geopressured reservoirs in some locations.8 The potential uses of such a relatively pure and easily accessibie natural gas are numerous.

Within the formation waters in geopressured zones of couth Texas coastal regions, salinities are commonly less than 20,000 ppm TDS and are often less than 5,000 ppm. Salinttles of south Loulslana geopressured zones are more uncertain. Salinitles generally exceed 100,000 ppm for thick; normally pressured sand units overlying the geopressured shale. Most of the Ions originally present in the formation waters are filtered out as they migrate from the shales toward the sand aquifers 8 . The benefits of low-salinity waters are twofold: (1) they can hold more methane in solution, and (2) with minimal desalination efforts they might be used to provide direct uses such as space heating, process heat, Irrigation, and human consumption. 
Economic, engineering, and environmental conditions define more specifically those areas where energy from geopressured zones would be most marketable. The currently accessible pore fluids, therefore, lie between the top of geopressure and the depth of we11 control (an estimated $6 \mathrm{~km}$ In Texas and $7 \mathrm{~km}$ in Louisiana).? The Wilcox and Frio formations contain sand beds of thickness required and form a system of fairways along the northern and western Gulf coast. The Eocene-W1lcox group is perhaps the oldest zone with geothermal potential. The linear development of sand covers an area $1,460 \mathrm{~km}$ long and $100 \mathrm{~km}$ wide, essentlally parallel to the coast. The top of geopressure is generally found at a depth of $3,000 \mathrm{~m}(10,000 \mathrm{ft})$ where temperatures average $120^{\circ} \mathrm{C}\left(250^{\circ} \mathrm{F}\right)$ but have been found in excess of $180^{\circ} \mathrm{C}\left(325^{\circ} \mathrm{F}\right)$; pressures are approximately $80 \mathrm{MN} / \mathrm{m}^{2}(11,600 \mathrm{psi}$ or near overburden pressure). Overall sediment thickness ranges from 700 to $1,700 \mathrm{~m}$. As calculated by Dorfman and Kehle, the power potential for the Eocene-Wilcox group would be approximately $7,400 \mathrm{MW}$ centuries (Table 1.3) for conversion of heat to electric power. ${ }^{6}$ Total potential energy exceeds this value due to the mechanical hydraulic energy of the high-pressure fluids and the chemlcal energy stored in methane gas.

In comparison, the pressured Frio sediments of Oligocene-Miocene age underlie more than $50,000 \mathrm{~km}^{2}$ of the Texas coastal plain. Properties and sand thickness of the Frio are similar to the Wilcox and may thus hold a potential exploitable geothermal reserve of 7,500 MW centuries. With these and other geopressured sand bodies considered, the overall 
Table 1.3. Calculation of geothermal potential in Wilcox Sand

Length of Wilcox Sand trend: $1,460 \mathrm{~km}$

Width of known geopressured zone: $40 \mathrm{~km}$

Areal extent of Wilcox geopressured zone: $58,400 \mathrm{~km}^{2}$

Average zone thickness in geopressured interval: $1,200 \mathrm{~m}$

Assuming $20 \%$ of interval is sand, average sand thickness: $240 \mathrm{~m}$

Estimated volume of geopressured sand: $14,000 \mathrm{~km}^{3}$

Assuming average porosity of sand is $15 \%$, vol. of water: $2,100 \mathrm{~km}^{3}$

Density of water: $1 \mathrm{~g} / \mathrm{ml}$

Mass of water: $2 \times 10^{18} \mathrm{~g}$

Bottom-hole temperature: $175^{\circ} \mathrm{C}$

Useful change in temperature: $75^{\circ} \mathrm{C}$

Heat capacity: $1.0 \mathrm{cal} /{ }^{\circ} \mathrm{C}-\mathrm{g}$

Useful change in enthalpy: $75 \mathrm{cal} / \mathrm{g}$

Total enthalpy: $1,575 \times 10^{18} \mathrm{~g}$-cal

Assuming a $14 \%$ efficiency in conversion to power,

Total useful enthalpy: $22.05 \times 10^{18} \mathrm{~g}$-cal $\times 1.16 \times 10^{-9} \mathrm{~g}$-cal $/ \mathrm{MWhr}=$ $25.62 \times 10^{9} \mathrm{MWhr}$, or $2.96 \times 10^{4} \mathrm{MW}$ centuries .

Power potential $=7,400 \mathrm{MW}$ centuries based on $25 \%$ reservoir depletion

Source: M. Dorfman and R. O. Kêhle, "Potential Geothermal Resources of Texas," Geological Circular 74-4, Bureau of Economic Geology, Univer-

sity of Texas, Austin, 1974. 
avallable electric power potential, as converted from heat, would be approximately $20,000 \mathrm{MW}$ centuries. 6

Total potential and exploftable energy for the northern Gulf coast is estimated between $552.4 \times 10^{18}$ and $17,000 \times 10^{18} \mathrm{cal}^{7}(25,900$ and 79,700 MN centurles, after the form of Dorfman and Kehle).

\subsection{PROPOSED GEOPRESSURE SUBPROGRAM ACTIVITIES}

The geopressure subprogram will explore a range of technical, economic, and institutional factors associated with developing the geopressured resources. The subprogram activities may be grouped into the categories of resource development, resource utilization, engineering research and development, and environmental control and institutional studies.

\subsubsection{Resource development activities}

Resource development support is focused on the areas of exploration technology, reservoir assessment, and reservoir confirmation. New techniques and instrumentation for exploration technology, Including high-temperature equipment and materials development, are being funded. Resource assessment will consist of (1) an assessment of the geopressured aquifers in Texas and Louisiana that uses existing well logs, seismic data, and micropaleoentological information; (2) the acquisition of specific reservoir information on a regional basis; and (3) the performance of well production tests. Two tests are currently planned for representative reservoir conditions. 
Short-term production tests on existing wells and longer-term tests on new wells will be performed to better define the factors affecting the development of extraction technology. Information w111 be sought for drilling, driliing completion, materials, corrosion, sand control, reservolr management, and well maintenance.

\subsubsection{Description of utilization projects}

Those specific utilization projects associated with the geopressure subprogram that have potential environmental impacts will each have an environmental assessment prepared as required. This section briefiy describes the presently planned projects to provide an overview of the projects associated with the subprogram. After information is obtained which confirms the feasibility of producing useful quantities of fluids, conversion technology for transforming the geopressured energy into a more usable form 111 be supported through the construction and operation of a pilot plant that uses a flashed-steam or binary-fluid power cycle. A representative site w111 be selected for this pilot plant. After demonstration of the selected power cycle, the pilot plant will be retrofiltered with an advanced power cycle, such as the total-flow concept. Geopressured fluid will be used for testing equipment and for Investigating scaling and corrosion problems. Some downhole technological developments may be attempted as well.

A pilot plant will also be constructed to test a system for generating electricity and producing natural gas from a geopressured reservoir. 
The site for the pilot plant has not been selected. A test facility for evaluating flowing wellhead conditions of geopressured fluids is also planned and will consist of test wells, experimental space, and test facilities. No site has yet been selected.

In addition, a market analysis for nonelectrical energy applications will be made, followed by the conceptual design of a geopressured heat distribution and utilization system.

\subsubsection{Englneering research and development activities}

ERDA is supporting engineering research and development to Identify and develop needed advances in geopressure resource development and utilization and engineering technologies. The drilling technology support involves improving existing methods and equipment to reduce the cost and environmental hazards of drilling and developing new drilling technology such as high-temperature drilling fluids and cements, and compacteddiamond drill bits. Utilization technology support is focused on developing advanced components and techniques for improving the reliability and efficiency of energy conversion processes. Geochemical engineering technology support will include basic and applied studies of geopressure fluid chemistry and materials technology for energy extraction.

\subsubsection{Environmenta1 control and institutional studies}

Environmental control and institutional studies will be supported to address the critical environmental, health, safety, policy, and 
Institutional considerations involved in making geopressure technology commerclally feastble. Activities include environmental studies, economic analysis, and policy and planning analysis for the overall geotherma1 RD\&D program and for the geopressure subprogram specifically.

\subsubsection{Existing geothermal technology}

With the exception of The Geysers geothermal operation in California, geothermal development in the United States has been confined to resource reconnaissance and assessment activities and a few nonelectrical applications. The present state of the art of technological developments is such that substantial energy production is possible from areas other than The Geysers, provided the proper incentives exist. Present technology would permit the production of electricity from low-salinity hightemperature fluids by direct-flash methods, the utilization of heat directly from low- to moderate-temperature fluids with low scaling potential, the recovery of some minerals and chemicals from suitably constituted fluids, and the desalination of moderate-salinity fluids to produce freshwater.

Present geothermal technology centers around the relatively clean, moderate- to high-temperature geothermal fluids and the dry steam at The Geysers. Since a substantial amount of the hydrothermal resource has high percentages of total dissolved solids, and since many geothermal resource areas have only low- to moderate-temperature flulds, this technology places an effective upper limit on the energy likely to be produced from geothermal reservoirs with current technology. 
Estimates of the total capacity of The Geysers reservolr vary, but it is possible that about $5,000 \mathrm{MWe}$ of capacity can be installed there within the foreseeable future. The IIquid-dominated reservolrs of the Imperial Valley and of other regions in the United States might be expected to contribute an additional 20,000 $\mathrm{MW}$ of electric and equivalent nonelectric capacity with existing technology by the year 1995 if development started soon. Thus, a total of 25,000 MWe of geothermal capacity might be installed with the existing technology.10 A cautious reminder, however, is that the only firm plans for installed capacity total just over 900 MWe by 1979 with expansion to about 1,500 MWe by 1985 (at The Geysers).

\subsubsection{Future development}

As stated earlier, the National Geothermal Energy R\&D Program was designed to stimulate geothermal development using existing technology as well as to promote new technologies for increasing the developable resource base. These new technologies involve resource development and utilization and concentrate primarily on the development of methods for using (1) the moderate-temperature fluids and the high-salinity fluids for electric production, (2) the low- to moderate-temperature fluids in nonelectrical applications, and (3) the geopressured energy and natural gas of the geopressured resource. The addition of this new technology to the resource base would increase the installed capacity in 1995. More important, the potential growth rate for new capacity would triple by the year 1986 or 1987 as compared with present technology. 


$$
1-21
$$

The ERDA geopressure subprogram is supporting efforts almed at encouragIng (1) the addition of the geopressured resource to the national energy base by the time the resource is likely to be in demand and (2) the for-

mation of an industry around the resource prior to that time.

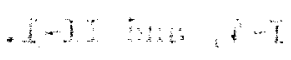

$\operatorname{arcos} i$ 


\section{REFERENCES FOR SECTION 1}

1. Energy Research and Development Administration, A National Plan for Energy Research, Development and Demonstration: Creating Energy Choices for the Future - Volume I: The PLan, ERDA-48, June 1975, pp. 5-2 and 5-3.

2. Geothermal Energy Research, Development and Demonstration Act of 1974, Public Law 93-410, September 3, 1975, Sect. 2.12.

3. Energy Research and Development Administration, Definition Report: Geothermal Energy Research, Development and Demonstration Program, ERDA-86, Division of Geothermal Energy, Washington, D.C., October 1975, pp. 5-6, I-4, and II-1.

4. Ref. 3, p. II-1.

5. Ref. 3, p. I-4.

6. M. Dorfman and R. O. Kehle, "Potential Geothermal Resources of Texas," Geological Circular 74-4, Bureau of Economic Geology, University of Texas, Austin, 1974.

7. S. S. Papadopulos, R. H. Wallace Jr., J. B. Wesselman, and R. E. Taylor, "Assessment of Onshore Geopressured-geothermal Resources in Northern Gulf of Mexico Basin," Geological Survey Circular 726, 1975.

8. M. H. Dorfman and R. W. Deller, Proceedings of Second Geopressured Geothermal Energy Conference, Volume I: Summary and Future Projections, University of Texas, Austin, February 1976.

9. D. G. Bebout, Proceedings of Second Geopressured Geothermal Energy Conference, Volume II: Resource Assessment, University of Texas, Austin, February 1976. 


$$
1-23
$$

10. Program Definition for the Development of Geothermal Energy:

Volume II: Program Definition Development Rationale and Subprogram Descriptions, Report 5040-6, Jet Propulsion Laboratories, Pasadena, Calif., Aug. 29, 1975, p. 2-25. 
Known geopressured resources with high potential for future development in the United States are all found within a narrow band along the TexasLouisiana Gulf Coast (see Sect. 1.4). For the purposes of this assessment, potential geopressured zones In the offshore continental shelf will not be considered.

Federal lands within national parks, national recreation areas, fish hatcheries administered by the Department of the Interior, wildilfe range, wildlife refuges, game range, wildilfe management areas, or waterfowl protection areas, and lands reserved for protection and conservation of wildife specles threatened with extinction are not aval1able for geothermal leasing or development and, therefore, will not be discussed.

2.1 GEOLOGY.

Along the Texas-Louisiana Gulf Coast, geopressured regions occur where the rapid accumulation of thick sedimentery strata has been accompanied by the entrapment of water at high pressure. Such conditions are not uncomon; geopressured reservoirs occur worldwide and are found assoclated with the South China Sea, the Red Sea, the North Sea, the Arctic Islands, and other former or present sedimentary basinst (Fig. 2.1). The Gulf of Mexico coastal geosyncline is the most extensive and wellunderstood high-pressured region and clearly exemplifies the geopressure 


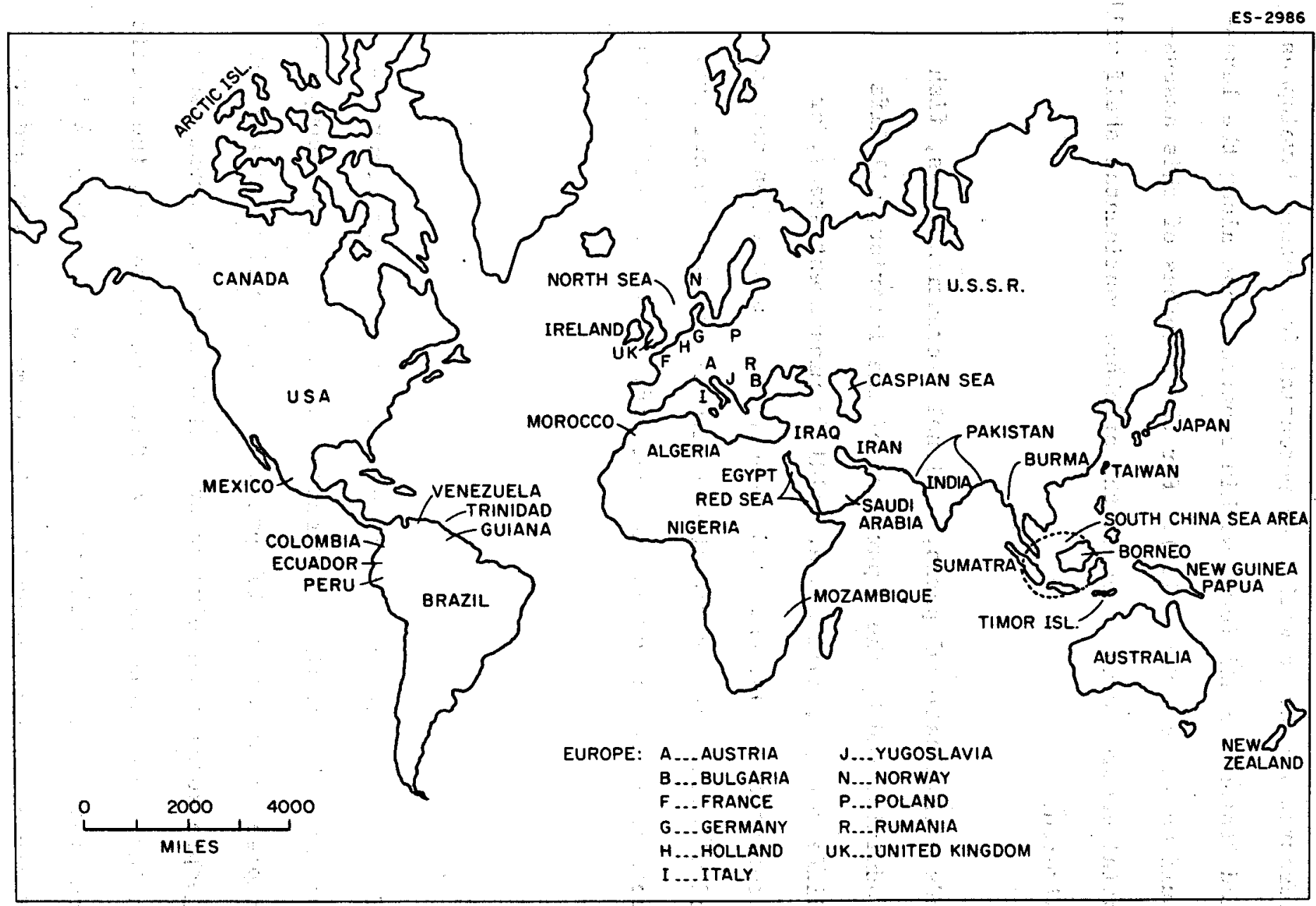

Fig. 2.1. World map of deep tertiary clastic basins. Source: Eugene Herrin, Development of Geothermal Reservoirs from Over-Pressured Areas Beneath the Gulf Coastal Plain of Texas. A Feasibility Study of Power Production from Overpressured Reservoirs, NTIS, U.S. Department of Commerce, Springfield, Va. 
processes assoctated with geosynclines: subsidence, rapid sediment accumulation, and growth fault development.

The Gulf of Mexico Iles within the Atlantic-Gulf coastal province of North America. Underlain by a basement of highly metamorphosed Paleozolc and pre-Cambrian rock, great thicknesses of Mesozolc and Cènozolc strata [up to $15,250 \mathrm{~m}(50,000 \mathrm{ft})$ ] make up the Gulf geosynclinal sequence and are exposed along the coastal area.

According to Meyerhoff et al.,$^{2}$ five major geological factors have Influenced the geosynclinal development of the Gulf Coast: (1) the structural grain of the Paleozolc Ouachita orogenlc belt determined the geometric form of the geosyncline; (2) a depression (the Gulf of Mexico) already existed as a potential site for geosynclinal formation; (3) the rate of subsidence remained equivalent to that of deposition; (4) the thick Louann Salt sequence of Triassic-Jurassic age provided an Important element of structural mobility within the geosyncline; and (5) the rising Rocky Mountains, beginning in Paleocene time, supplied large volumes of sediment for eventual deposition along the Gulf Coast. of these major factors, rapid sedimentation and subsidence were particularly significant in the development of the geosyncline's eventual geopressure environment.

During the geosyncline's formation, growth faults developed subparallel to the geosynclinal axis and Texas-Loulsiana coast (Fig. 2.2). Growth faults are normal faults which have a substantial Increase in vertical displacement with respect to depth and a great thickening across the 


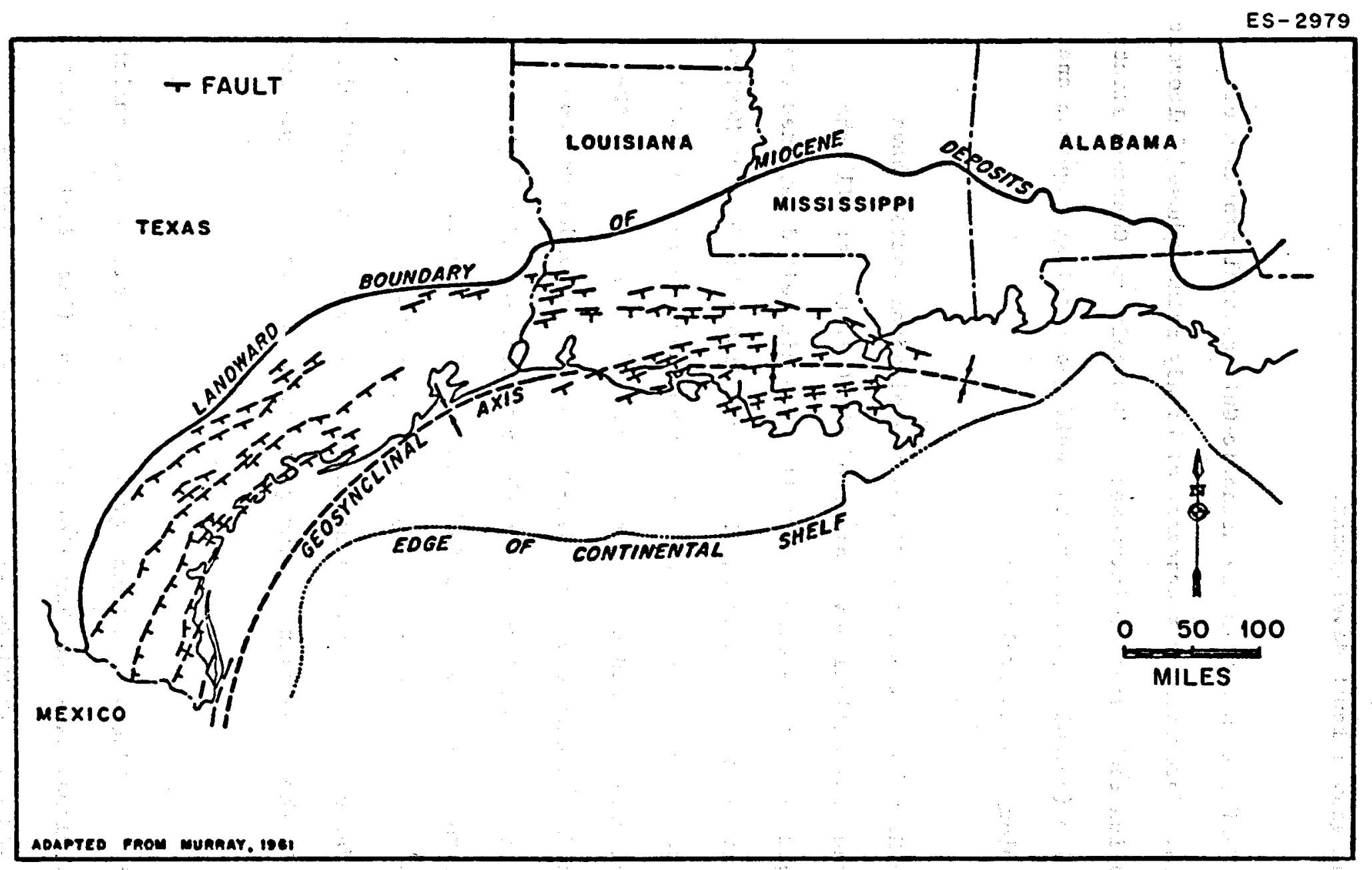

Fig. 2.2. Principal reglonal normal faults and landward boundary of miocene deposits - northern Gulf of Mexico Basin. Source: Eugene Herrin, Development of Geothermal Reservolrs from Over-Pressured Areas Beneath the Gulf Coastal Plain of Texas. A Feastbility Study of Power Production from Overpressured Reservolrs, NTIS, U.S. Department of Commerce, Springfield, Va. 
section from the upthrown to the downthrown block. ${ }^{3}$ These faults form arcuate patterns where particularly large deposits develop on the downthrown, Gulfward blocks.

The cause of such faulting is not well understood. Jones believes it may be initiated by a greatly increased overburden pressure. ${ }^{4}$ As sediments continue to expand seaward into the Gulf, underlying muds and clays cause growth faults to form along planes of structural weakness In areas of heavy influx. A continuing cycle develops as growth faults allow greater overburden pressure which, in turn, causes further faulting.

Rubey and Hubbert have proposed another mechanism whereby growth faults develop in regions of abnormally high fluid pressure. 5 Gravity sliding Is activated where the high fluid pressure has reduced the shearing strength of the rock. The strata then move along bedding and other planes of weakness. At the head of the sliding block with movement occurring only on the downthrown side, gravity or normal (growth) faults result.

These two theories are essentially in agreement except for the factor of time sequence. Faulting because of excessive fluid pressure obvious ly would occur following the development of geopressured strata. In contrast, faulting Induced by overburden could occur before or during the establishment of geopressured conditions. However, elther mechanism, in conjunction with rapid sedimentation and subsidence, enables downthrown blocks to accumulate the large amounts of clastic units assoclated with the geopressured regime. 
Gulf Coast Tertlary sediments may reach thicknesses of $15,250 \mathrm{~m}$ $(50,000 \mathrm{ft})$ or more; ${ }^{1}$ formations of the Cenozic-Texas Gulf Coast are 1isted in Fig. 2.3. The lower and middle strata comprise a thick shale sequence where water entrapment and abnormally high fluid pressures have developed. These shales are Interbedded with sand lenses that are 1solated by pinching out or faulting. Within the shale sequence, most geopressured zones occur within or below the 011gocene-Frio Formation. 6 The upper, normally pressured strata consist mostly of sands. 7,8

Following deposition, the density of these units is largely determined by porosity. Because nelther clay particles nor water are readily compressible, any sediment compaction implies a reduction in porosity and an expulsion of interstitial fluids. As sediments are added to the overburden, Interstitial waters are expelled, and the clay beds gradually consolidate. However, while compaction continues, the rate of fluid expulsion lessens due to a continuous decrease in shale porosity and permeability. In relation to the Gulf Basin, the continual decrease in fluid movement has evolved simultaneously with increases in sedimentation and overburden pressure along the fronts of seaward expanding delta systems. Eventually, fluid movement from the shales is restricted. According to Jones, ${ }^{4}$ no reliable measurements for permeability are avallable, though Papadopulas et al. ${ }^{9}$ arbitrarily designates a value of only 0.0001 millidarcies (md) for the high-pressured shales. Water can no longer be forced into the distant overlying strata, and further compaction is prevented. The interstitial fluids begin to assume part of 
ES -2980

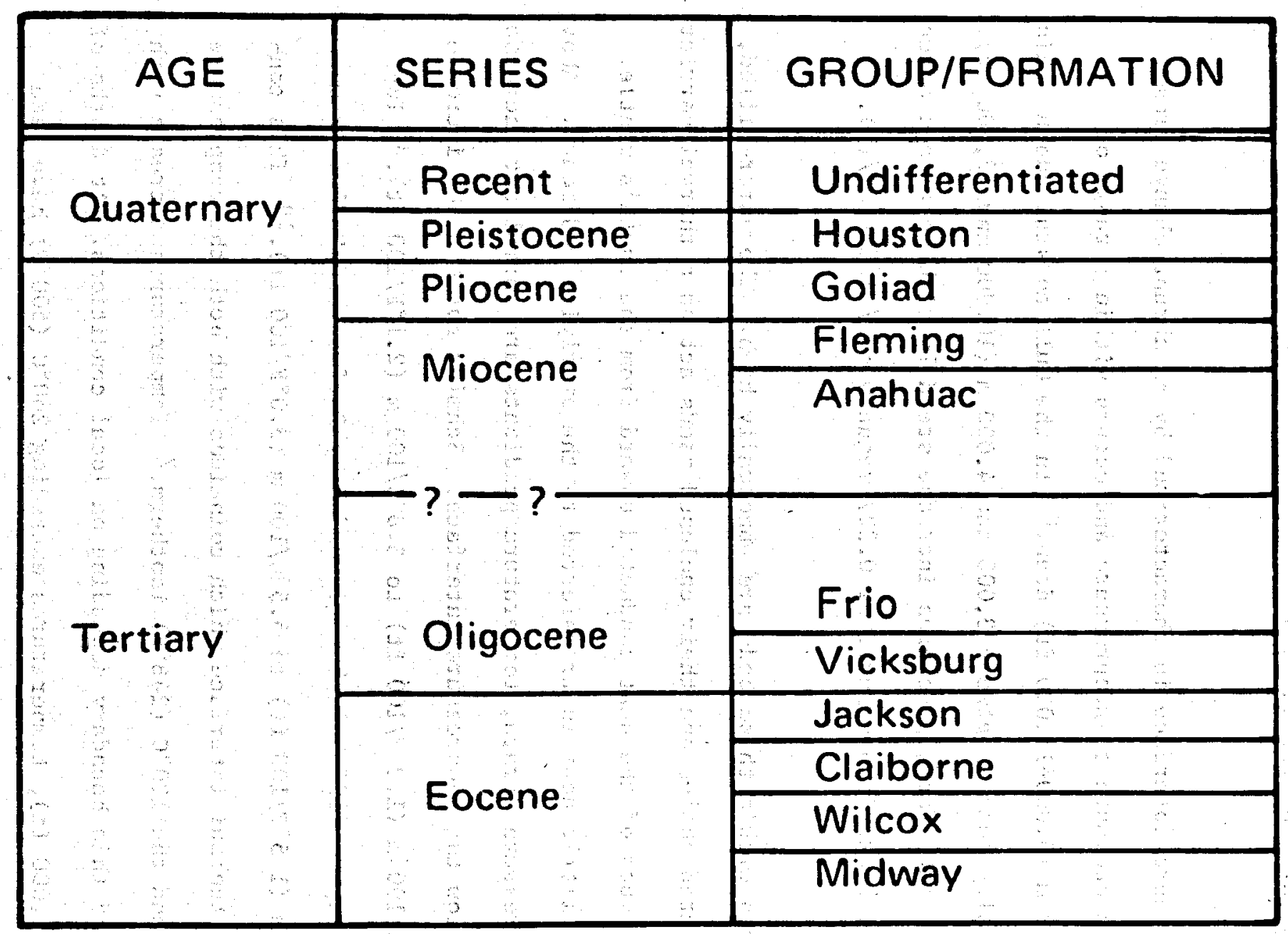

Fig. 2.3. Tertiary formations - Gulf Coast of Texas. Source: D. G. Bebout, Proceeding of Second Geopressured Geothermal Energy Conference, Volume II: Resource Assessment, University of Texas, Austin, February 1976. 
the overburden load such that pore pressure ultimately exceeds hydrostatic pressure, or 0.0106 meganewtons $/ \mathrm{m}^{3}(0.465 \mathrm{psi} / \mathrm{ft})$. This condition constitutes "geopressure."

The geopressure interface is characterized by an abrupt change from hydrostatic pressure to geopressure and occurs within a range of $1,500-4,500 \mathrm{~m}(5,000-15,000 \mathrm{ft})$ deep. ${ }^{8}$ In the Gulf coastal bas in, this change usually occurs between 3,000 and $4,000 \mathrm{~m}$ (10,000 and $12,000 \mathrm{ft})$. Beyond this interface, pressures increase steadily with depth and often approach lithostatic pressure, or 0.227 meganewtons $/ \mathrm{m}^{3}(1 \mathrm{ps} / \mathrm{ft})$.

Temperatures within these beds are abnormally high. The water-filled, undercompacted shales and their enclosed sands act as a thermal barrier and retain much of the heat conducted upward from the Earth's mantle. Relatively little heat is transferred to the overlying sediments. Above the high-pressure strata, temperature gradients are normal but increase sharply below the geopressure interface. Schmidt notes a $60 \%$ increase from $2.3^{\circ} \mathrm{C} / 100 \mathrm{~m}\left(1.3^{\circ} \mathrm{F} / 100 \mathrm{ft}\right)$ to $3.8^{\circ} \mathrm{C} / 100 \mathrm{~m}\left(2.1^{\circ} \mathrm{F} / 100 \mathrm{ft}\right) .^{8} \mathrm{In}-$ creases of up to $100 \%$ have been recorded by Dorfman and Deller from $2.7^{\circ} \mathrm{C} / 100 \mathrm{~m}\left(1.5^{\circ} \mathrm{F} / 100 \mathrm{ft}\right)$ to $5.5^{\circ} \mathrm{C} / 100 \mathrm{~m}\left(3.0^{\circ} \mathrm{F} / 100 \mathrm{ft}\right) .10 \mathrm{Th}$ is constitutes a thermal interface which colncides with both the geopressure Interface and the $120^{\circ} \mathrm{C}\left(248^{\circ} \mathrm{F}\right)$ isotherm. ${ }^{7}$ Temperatures increase with depth beyond this boundary depending on local conditions. At depths of $6,000 \mathrm{~m}(20,000 \mathrm{ft})$, temperatures exceeding $260^{\circ} \mathrm{C}\left(500^{\circ} \mathrm{F}\right)$ have been found. 7 
The geopressured fluids origlnate from two major sources. Most of the interstitial fiud consists of water confined during initial deposition. Secondly, free water is liberated by the alteration of the clay mineral montmorillonite to the less hydrous clay, 1llite. Montmorillonite is a major constituent of these muds as they are Initially lald down.11

Characterized by an expanding lattice, this hydrous mineral absorbs two layers of crystalline water on its surface. At high temperatures between $80^{\circ}$ and $120^{\circ} \mathrm{C}\left(176^{\circ}\right.$ and $\left.248^{\circ} \mathrm{F}\right)$, it converts to llite and releases the crystalline water. ${ }^{4}$ These temperatures colnclide in part with the geopressure interface and $120^{\circ} \mathrm{C}$ isotherm, which implies that much of the water bound to montmorillonite is 11berated within geopressured shales.

Because these waters are confined within essentially impermeable shales, compaction is minimal. In the Gulf reglon, shale densities at depths of $4,500 \mathrm{~m}(15,000 \mathrm{ft})$ are approximately $2.4 \mathrm{~g} / \mathrm{cm}^{3}$. The ultimate density of well-compacted shale $182.65 \mathrm{~g} / \mathrm{cm}^{3}$, which Implies that large volumes of water remain to be expelled from the undercompacted strata. 12

Porosity within a single shale bed may vary. The greatest amount of compaction has occurred along the beds' margins; thus, there is a general decrease in porosity from the shale's central zone to its outer contacts with sand aquifers. As noted by Magara, the results of this are twofold.13 First, as porosity decreases, fluid pressure also decreases. Therefore, water migrates from the central zone to the shales margins and towards the sands. This constitutes compaction flow. Secondly, salinity increases as the porosity decreases due to the greater filtering 
capabilities of less porous sediments. As water passes through the lowporosity shale boundary, salt lons become trapped. A salinity gradient results and causes an osmotic flow of water from the central zone toward the more saline outer margins. The direction of osmotic flow within the shale thus parallels that of compaction flow.

Both compaction and osmotic flow are facilitated by the dehydration of montmorillonite. During conversion to illite, free water (15\% by volume) is Iiberated. This increases both fluid and osmotic pressures within the central zone and promotes water migration from the shales' central zones to the sands. 7

The direction of fluid migration coincides with the movement of dissolved gases. It is estimated that most or all of the hydrocarbon sources with the Gulf basin originate in the Cenozolc shales. Within the geopressured fluids, nearly all of the hydrocarbon resource consists of natural gas, primarily methane.

Ethane and propane are present in minute quantities, and only minimal concentrations of heavier hydrocarbons are found, with little or no evidence of hydrogen sulfide $\left(\mathrm{H}_{2} \mathrm{~S}\right)$ or other contaminants. 10 The dissolved gases flow from areas of greater concentration in the shales to areas of least concentration in the sands. Water freshening within both the sands and shales aids this process by allowing greater amounts of natural gas to be dissolved in the less saline water. ${ }^{13}$ 
Many of the sand lenses within the Teritiary sequence are completely 1solated. According to Bebout, the Frio, Vicksburg, and Wilcox formations contain the more extensive sand bodies within or beneath the geopressured shales. 6 The shales are relatively impermeable and envelop the porous sandstones by (1) "pinching out" of the sand lenses, or by (2) faulting of the sand beds along growth faults (Fig. 2.4).

Large volumes of water are confined within the lsolated and moderately consolidated sands. Porosities range from $18-22 \%$ by volume, and permeabilities average $29 \mathrm{md} .9$ Unlike the surrounding geopressured shales, these sand beds are not undercompacted to any major extent and, therefore, maintain most of their interstitial spacing. Papadopulas et al. $(1975)^{9}$ and Herrin $(1973)^{1}$ assign a value of only $3 \times 10^{-6} / \mathrm{psi}$ for the compressibility of sand aquifers.

Under these conditions, the sand lenses act as excellent reservolrs for geopressured fluids. As stated earlier, compaction and osmotic flow originate within the geopressured shales and move slowly outward past the shale margins into the sands. Dissolved natural gas follows a simflar flow path. As a result, the sand reservolr fluids are high in methane and low in sallnity; dissolved solids are generally less than $20,000 \mathrm{ppm}$ and often less than 5,000 ppm in many geopressured reservoirs of coastal regions in South Texas 10 Pressures and temperatures within these beds are similar to those of the surrounding geopressured area. 
ES- 2984

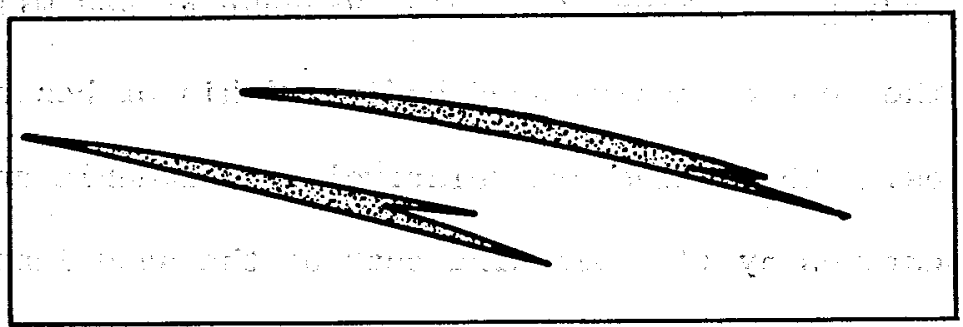

(A) SMALL RESERVOIR SEALED BY PINCHOUT

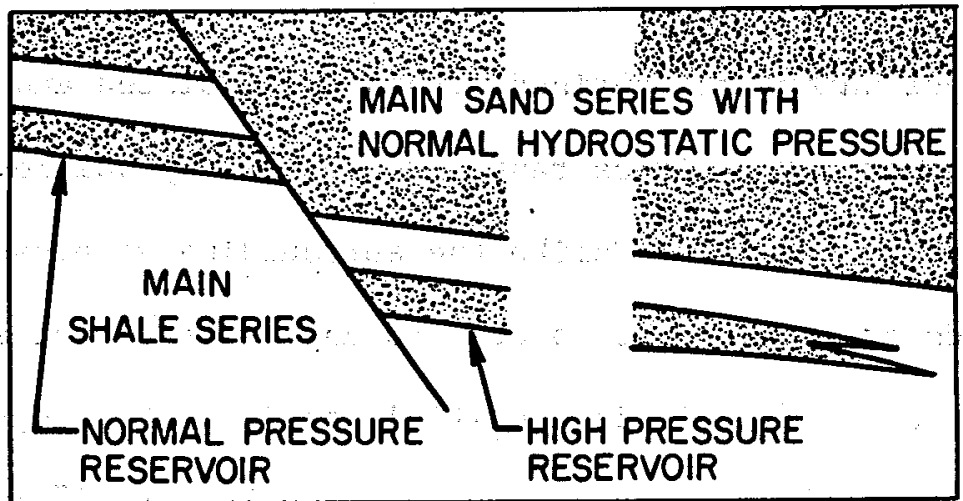

(B) LARGE RESERVOIR SEALED UPDIP BY FAULTING DOWN AGAINST THICK SHALE SERIES, SEALED DOWNDIP BY REGIONAL FACIES CHANGE

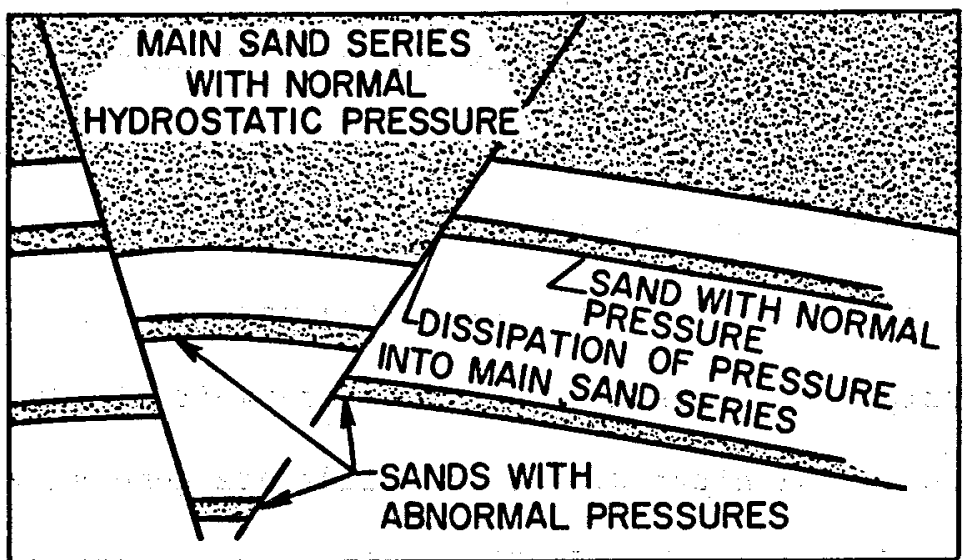

(C) RELATIVE POSITION OF FAULT SEALS IN UPTHROWN AND DOWNTHROWN BLOCKS

F1g. 2.4. Types of reservolr seals necessary to preserve abnormal pressure. Source: P. A. Dickey, C. R. Shiram, and W. R. Paine, "Abnormal Pressures in Deep Wells in Southwestern Loulsiana, Science, vol. 160, 1968. 
Salinities In south Loutstana and coastal regions of east Texas are more uncertain. Whereas few salt domes have Intruded into the geopressured shales $160 \mathrm{~km}$ ( $100 \mathrm{miles})$ to either side of Corpus Chrlst1, Texas, they are far more numerous east of Houston. 14 If a salt dome is nearby, formation waters are likely to be more saline.

Salt dlapirs, of ten termed salt domes; are common features of the Gulf of Mexico basin. They are believed to originate in the Louann salt formation, a 5000-ft-thick evaporite formation of the Triassic-Jurassic age. 14 Though such structures are not essential to the development of geopressured zones, their presence directly affects the nature of the high-pressured strata and Interstitial fluids.

As a result of density differentials, salt domes frequently exhibit diapiric movement - the intrusion of a plastic solid into another solid. According to Blllings, average sediment densities range from 1.9 to 2.2 $\mathrm{g} / \mathrm{cm}^{3}$ and to a depth of $600 \mathrm{~m}(2,000 \mathrm{ft}) .15$ Beyond this point, density Increases steadily to $2.46 \mathrm{~g} / \mathrm{cm}^{3}$ at a depth of $6,000 \mathrm{~m}(20,000 \mathrm{ft})$. However, the density of salt remains relatively constant at $2.2 \mathrm{~g} / \mathrm{cm}^{3}$ regardless of depth. Thus, below $600 \mathrm{~m}$, an unstable gravitational situation exists where a less-dense salt facies is overlain by heavier strata. Facllitated by its plastic behavior at temperatures exceeding $300^{\circ} \mathrm{C}\left(540^{\circ} \mathrm{F}\right)$, the salt moves upward in the same manner as a light fluid rises through a heavier fluid. 
Salt intrusions directly affect surrounding structure, temperature, and fluld composition. An intruding salt dome will often induce radiating or normal faulting in the overlying beds thus creating traps within reservolr rock. The sealed-off beds often contain large amounts of hydrocarbons and are. the object of extensive petroleum exploration.

In addition, salt within the dlapirs, may contaminate the otherwise freshened geopressured waters. Lowest salinities might be expected in areas such as the San Marcos Arch near Corpus Christi, Texas, where no salt structures are apparent. Temperatures may also be influenced. Salt has a high thermal conductivity $\left(17 \times 10^{-3} \mathrm{cgs}\right)$ compared with that of surrounding sediments (from 1 to $8 \times 10^{-3} \mathrm{cgs}$ ). Acting as large heating rods, the diapirs range from 3 to $8 \mathrm{~km}$ in diameter and extend to depths of $15 \mathrm{~km}$ or more: 4 Therefore, heat can be conducted upward rapidly through the salt domes and into the surrounding geopressured shale:

\subsection{CLIMATOLOGY AND AIR QUALITY}

The Texas-Louisiana Gulf Coast lies within a warm-temperature, subtropical zone. The mild climate of this area is predominantly due to the warm, moist air masses originating over the Gulf of Mexico, the Carribean Sea, and the southern North Atlantic Ocean. However, this mild condition periodically changes because of drier, continental air from the north and west which brings both colder winter temperatures and hotter temperatures during summer. 
Average annual temperatures are moderate and decrease stead11y northward from $23.8^{\circ} \mathrm{C}\left(75^{\circ} \mathrm{F}\right)$ at the mouth of the Rio Grande River to $20.0-20.6^{\circ} \mathrm{C}$ : $\left(68-69^{\circ} \mathrm{F}\right)$ along southern Louislana. 16 January temperatures average from $13.9^{\circ} \mathrm{C}\left(57^{\circ} \mathrm{F}\right)$ in Louisiana to $16.3^{\circ} \mathrm{C}\left(61.4^{\circ} \mathrm{F}\right)$ in Brownsville, Texas 17,18 Generally confined to the several hours preceding sunrise, subfreezing temperatures are relatively rare and occur an average of ten days or less per year. 16 sumer temperatures along the coast peak in July and August. Extremes of $32.2^{\circ} \mathrm{C}\left(90^{\circ} \mathrm{F}\right)$ or greater may occur from 57 days/year in New Orleans to 86 days/year in Lake, Charles and up to 120 days/year in southern Texas 16,18

The coastal margins experience moderate to high relative humidity. Monthly relative means generally exceed $60 \%$ and may reach $80 \%$ or more during the wetter sumer months. Annual preclpitation is high and Increases steadily northward from $50,8 \mathrm{~cm}$ (20 in.), along the Rio Grande to $147.3 \mathrm{~cm}(58 \mathrm{In}$.$) on the Texas-Loulsiana border and to 162.6 \mathrm{~cm}$ (64 In.) along parts of southern Louisiana, 16 The driest season occurs during the fall months, while torrential rains of $25.4-50.8 \mathrm{~cm}$ (10-20 In.) often develop in late spring due to squal1-1ine thunderstorms:17? falls of $25.4 \mathrm{~cm}$ (10 in.) within a $24-\mathrm{hr}$ period are not uncomon. 18 Summer rains frequent the northern coastal margins almost daily and accumulate an average seasonal precipitation of $58.9 \mathrm{~cm}(22 \mathrm{in})$ along southeast Louistana parishes. 18 ,

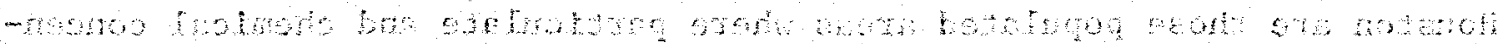
Long periods of clear weather of ten occur throughout the year, and during winter and early spring fair conditions dominate the area. The growing 
season ts generally long with a mean annual sunshine ranging from $2,700-2,900$ hr per year. 16

Showers and thumderstorms frequent the Gulf Coast along Its western and northern margins. Occurrences of turbulent weather range from $70-80$ days/year in southern Louistana ${ }^{18}$ to 60 days/year in Texas. ${ }^{17}$ Troplcal - cyclones comonly reach the coastal areas during a season that extends from June to September and reach thelr peak during August and September. These storms originate In the Gulf, Carribean, or southern North Atlantic Ocean and average one tropical cyclone per year along the Texas Coast. 17 Those cyclones whose winds exceed 64 knots (74 mph) are known specifically as hurricanes and average 40 storms/100 years or $40 \%$ of all troplcal Texas-Loulstana storms 18

Tornadoes also develop In this area and may occur during all times of the year. However, they are most frequent in a season ranging from March through May in Louislana and April through June in Texas.17,18 Many of these tornadoes result from major tropical cyclones off the Gulf Coast. In 1967, Hurricane Beulah was the cause of 115 tornadoes in the surrounding area. 17

The air quality of coastal Loulsiana and Texas is generally good because of the states' proximity to the Gulf. New Orleans, Baton Rouge, and Houston are those populated areas where particulate and chemical concentrations pose the greatest problems. Tables 2.1 and 2.2 1ist particulate 
Table 2.1. Estimated annual concentration ranges of suspended particulates (1961-1965) $>0$

\begin{tabular}{ccc} 
City & \multicolumn{1}{c}{ Micrograms per cubic meter } \\
\cline { 2 - 3 } & Potal & Organic \\
& Particulate & Particulate \\
\hline New Orleans, La. & $93-105$ & $8.2-9.8$ \\
Baton Rouge, La. & $106-135$ & $8.2-9.8$ \\
Lake Charles, La. & $77-92$ & 5.1 or less \\
Houston, Tex. & $93-105$ & $6.7-8.1$ \\
Galveston, Tex. & 76 or less & 5.1 or less \\
Corpus Christi, Tex. & $77-92$ & 5.1 or less \\
Harlington, Tex. & $77-92$ & 5.1 or less
\end{tabular}

Source: Department of the Interior, Geological Survey, The National Atlas, Washington, D.C., 1970, p. 115. of sulfur dioxide $\left(\mathrm{SO}_{2}\right)(1961-1965)$

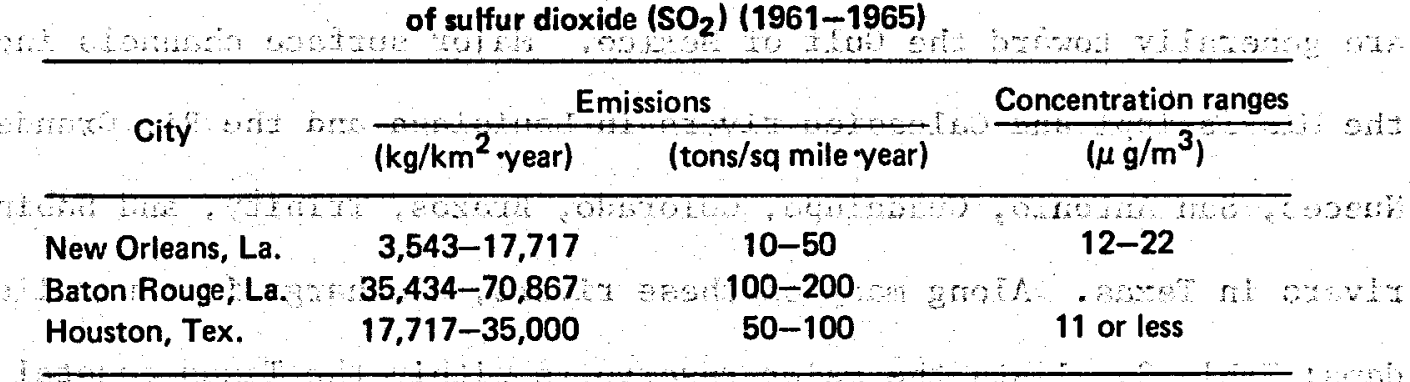

Source: Department of the Interior, Geological Survey, The National Atlas,

Yashington, D.C., 1970, p. 115.

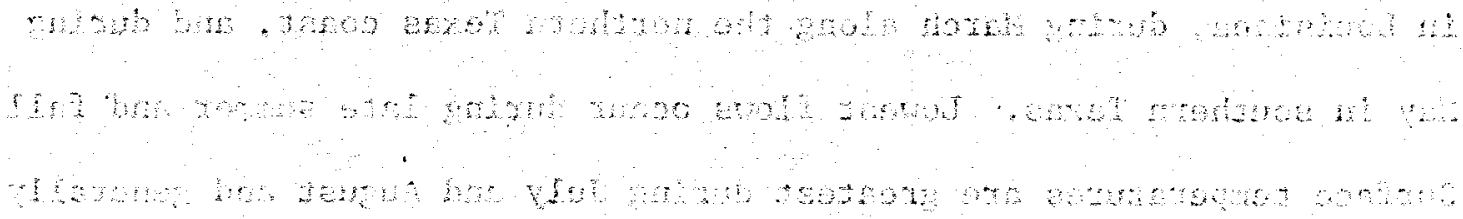


and sulfur dioxide concentrations for major cities from New Orleans to Harlingen, Texas.

Because the Gulf of Mexico is a warm body of water, it contributes to the alr turbulence over the Gulf. This creates a horizontal diurnal wind pattern during the fall and winter months characterized by daytime sea breezes and nighttime land breezes. In contrast, verticpl patterns of air movement develop during late spring and summer. Both patterns aid in the mixing of large volumes of air and therefore favor a very low alr-pollution potential (Fig. 2.5, Table 2.3). However, the frequent occurrence of light winds ( $7 \mathrm{mph}$ or less) and periodic temperature inversions may contribute to some pollution problems, particularly at night. 17

\subsection{HYDROLOGY}

Surface and groundwater flow patterns along the Texas-Loulsiana coast are generally toward the Gulf of Mexico. Major surface channels include the Mississippi and Calcasieu rivers in Louisiana and the Rio Grande, Nueces, San Antonio, Guadalupe, Colorado, Brazos, Trinity, and Sabine rivers in Texas. Along many of these rivers, discharge 1s controlled by dams; Table 2.4 1ists the major reservoirs within the Texas coastal margin and their storage capacities. Surface flows peak during January In Louisiana, during March along the northern Texas coast, and during May in southern Texas. Lowest flows occur during late sumer and fall. Surface temperatures are greatest during July and August and generally 


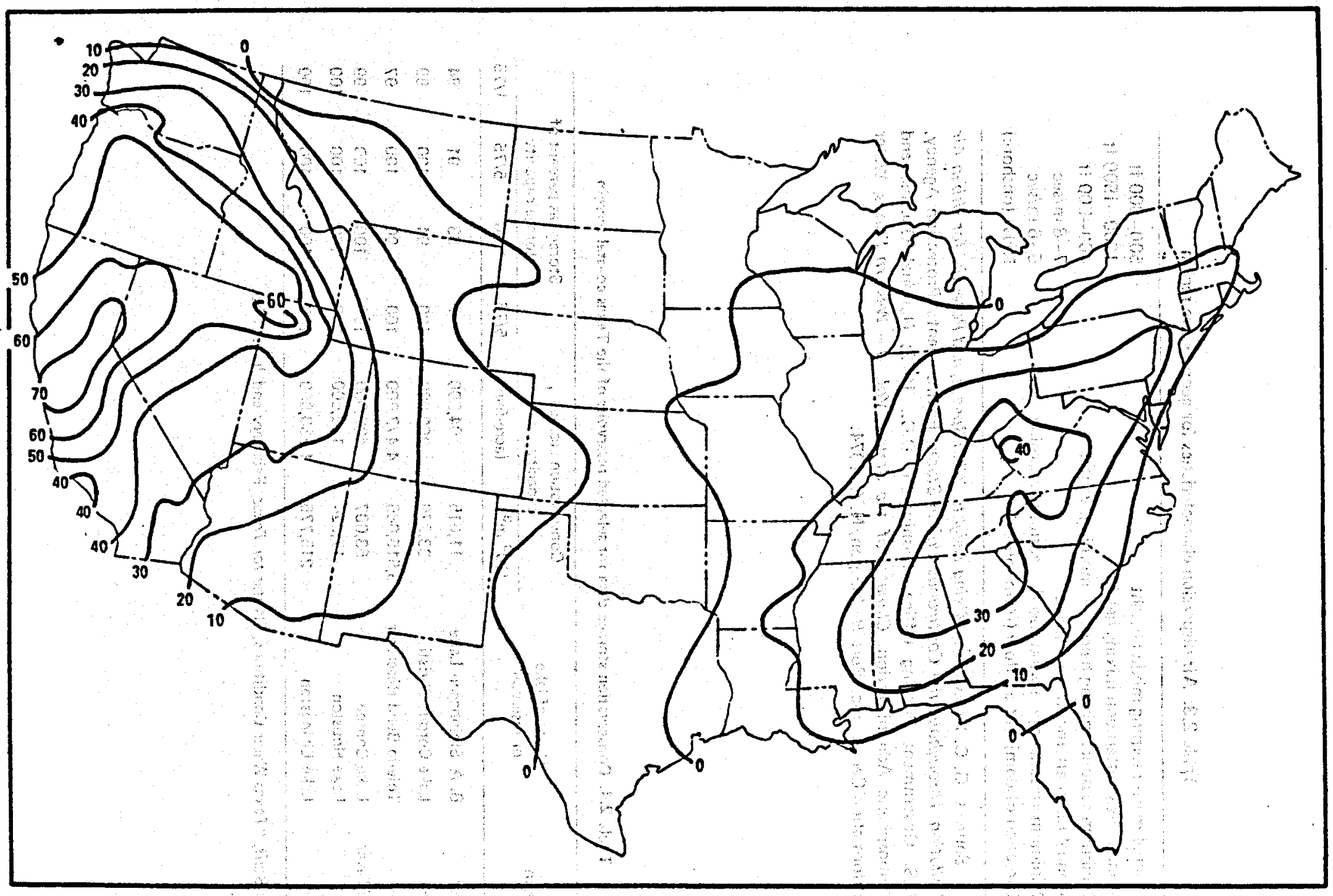

Fig. 2.5. Isopleths of total number of forecast-days of high meteorological potential for air pollution in a five-year period. Data are based on forecasts issued since the program began (August 1, 1960 and October 1, 1963 for, eastern and western parts of the United States, respectively) through April 3, 1970. Source: G. C. Holzworth, Mixing Heights, Wind Speeds, and Potential for Urban Air Pollution Throughout the Contiguous United States, Environmental Protection Agency, U.S. Government Printing office, Washington, D.C., 1972. 
Table 2.3. Air dispersion characteristics for geopressure region

Annual mean morning mixing height

$500-900 \mathrm{ft}$

Annual mean afternoon mixing height

$1200-1500 \mathrm{ft}$

Minimum seasonal mixing height - morning, winter

$400-500 \mathrm{ft}$

Annual mean afternoon wind speed

$7-8 \mathrm{~m} / \mathrm{sec}$

Minimum seasonal mean wind speed - autumn, morning

$5-6 \mathrm{~m} / \mathrm{sec}$

Direction of dominant air flow (from source)

NNW (onshore)

Sources: G. C. Holzworth, Mixing Heights, Wind Speeds, and Potential for Urban Air Pollution Throughout the Contiguous United States, Environmental Protection Agency, U.S. Government Printing Office, Washington, D.C., 1972; National Oceanic and Atmospheric Administration, Climates of the States: Vol. II-Western States, Water Information Center, Inc., Port Washington, N.Y., 1974.

Table 2.4. Conservation storage data for selected reservoirs of the Texas coastal margin

\begin{tabular}{|c|c|c|c|c|c|c|c|}
\hline \multirow[t]{2}{*}{ River bașin } & \multirow{2}{*}{$\begin{array}{c}\text { Name of lake } \\
\text { or reservoir }\end{array}$} & \multicolumn{2}{|c|}{$\begin{array}{c}\text { Conservation storage } \\
\text { capacity }\end{array}$} & \multicolumn{4}{|c|}{$\begin{array}{c}\text { Storage as percent of } \\
\text { storage capacity }\end{array}$} \\
\hline & & $\left(10^{3} \mathrm{~m}^{3}\right)$ & (acre-feet) & $5 / 76$ & $1 / 76$ & $5 / 75$ & $1 / 75$ \\
\hline Neches River & B. A. Steinhagen Lake & 11,615 & 94,200 & 77 & 63 & 91 & 84 \\
\hline Nueces River & Lake Corpus Christi & 33,279 & 269,900 . & 100 & 94 & 100 & 99 \\
\hline Sabine River & Toledo Bend Reservoir & $5,515,086$ & $4,472,900$ & 100 & 90 & 100 & 97 \\
\hline San Jacinto River & $\begin{array}{l}\text { Lake Conroe } \\
\text { Lake Houston }\end{array}$ & $\begin{array}{l}53,007 \\
17,324\end{array}$ & $\begin{array}{l}429,900 \\
140,500\end{array}$ & $\begin{array}{l}100 \\
100\end{array}$ & $\begin{array}{l}100 \\
100\end{array}$ & $\begin{array}{l}100 \\
100\end{array}$ & $\begin{array}{r}99 \\
100\end{array}$ \\
\hline Trinity River & Lake Livingston & 215,775 & $1,750,000$ & 100 & 100 & 100 & 100 \\
\hline
\end{tabular}

Source: Staff, "Texas Water Conditions," Water for Texas, February and June 1976. 
fall between 26.7 and $29.4^{\circ} \mathrm{C}\left(80^{\circ}\right.$ and $\left.85^{\circ} \mathrm{F}\right)$. Annual water evaporation from streams, reservolrs, and lakes range from $168 \mathrm{~cm}(66 \mathrm{in.})$ in southern Texas to $122 \mathrm{~cm}$ (48 in.) In Loulsiana. Inland surface water salinities vary according to location and exceed $350 \mathrm{ppm}$ near the Texas coast. Concentrations are generally less in Loulsiana (120-350 ppm) and may fall below $120 \mathrm{ppm}$ in some areas. 19 Available water quality data for selected surface waters are summarized in Table 2.5 .

Along much of the coastline, estuaries occur where fresh inland waters mix with the waters of the Gulf of Mexico. Estuarine waters are brackish and generally display salinfties near 12,000 or 15,000 ppm. However, salinities are seasonal and may vary greatly because of seasonal changes In tides, rainfall, river discharge, and evaporation rates. Concentrations may fluctuate from $100 \mathrm{ppm}$ (freshwater) to 33,000 or $35,000 \mathrm{ppm}$ (seawater), and are generally highest in the fall and lowest during peak river discharges. Water temperatures are also seasonal and generally follow air temperatures. Dissolved oxygen fluctuates throughout the year and is highest during conditions of low water temperature and salinity. Turbidities may vary with river discharge and wind speed.20

Nearly all groundwater sources of the Texas-Louislana coast are held in unconsolidated or semiconsolidated aquifers. 19 These water-bearing formations act as conduits for water transmission and as reservoirs for storage. 21 The major aquifers are predominantly shales and/or sands and include the Gulf Coast aquifer along most of the coastal area and the Ogallala aquifer along the Brazos River basin. 22 Further 1llustration 
Table 2.5. Water quality data for selected surface-water systems of coental Texes and Louisiana

\begin{tabular}{|c|c|c|c|c|c|c|c|c|c|c|c|c|}
\hline \multirow[b]{2}{*}{$\begin{array}{l}\text { River } \\
\text { (water quality station) }\end{array}$} & \multirow{2}{*}{$\begin{array}{c}\text { Mean } \\
\text { Discherge } \\
\left(\mathrm{m}^{3} / \mathrm{s}\right)^{2, b}\end{array}$} & \multirow{2}{*}{$\begin{array}{c}\text { Mean Discharge } \\
\text { Range } \\
\left(\mathrm{m}^{3} / \mathrm{s}\right)^{c}\end{array}$} & \multirow[b]{2}{*}{$\mathrm{pH}^{*}$} & \multicolumn{9}{|c|}{ Average concentrations in mg/liter, water year September 1967 to October 1968} \\
\hline & & & & $\begin{array}{l}\text { Dissolved solids } \\
\text { (sum of con- } \\
\text { stituents) }\end{array}$ & $\begin{array}{l}\text { Silica } \\
\left(\mathrm{SiO}_{2}\right)^{\mathrm{c}}\end{array}$ & $\begin{array}{l}\text { Bicarbonate } \\
\left(\mathrm{HCO}_{3}\right)^{c}\end{array}$ & $\begin{array}{l}\text { Nitrate } \\
\left(\mathrm{NO}_{3}\right)^{6}\end{array}$ & $\begin{array}{l}\text { Sulfate } \\
\left(\mathrm{SO}_{4}\right)^{c}\end{array}$ & $\begin{array}{l}\text { Chioride } \\
\left(\mathrm{CI}^{c}\right.\end{array}$ & $\begin{array}{l}\text { Fluoride } \\
\left(\mathbf{F ) ^ { c }}\right.\end{array}$ & $\begin{array}{c}\text { Sodium } \\
(\mathrm{Na})^{\mathrm{C}}\end{array}$ & $\begin{array}{l}\text { Calcium } \\
\text { (Ca) }{ }^{c}\end{array}$ \\
\hline $\begin{array}{l}\text { Brazos } \\
\text { (Richmond, Tex.) }\end{array}$ & $208^{\circ}$ & $20-1786$ & 7.8 & 352 & 8.0 & 161 & 1.9 & 54 & 78 & 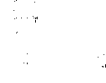 & 54 & 61 \\
\hline $\begin{array}{l}\text { Calcasieu } \\
\text { (Oberlin, Lo.) } \\
\text { (Mean discharge: } \\
\text { Kinder, La.) }\end{array}$ & $71^{\circ}$ & $1.4-94$ & 6.7 & 82 & 14.6 & 53 & 0.7 & ${ }^{8.8}$ & 5.4 & 0.1 & 17 & 7.4 \\
\hline $\begin{array}{l}\text { Colorado } \\
\text { (Wharton, Tex.) }\end{array}$ & $81^{\circ}$ & $18-1200.0$ & 7.9 & 253 & 8.6 & 178 & 1.5 & 30 & 37 . & $\therefore$ & 24 & 50 \\
\hline $\begin{array}{l}\text { Guadalupe } \\
\text { (Victoria, Tex.) }\end{array}$ & $45^{\circ}$ & $27-560$ & 7.9 & 300 & 11 & 222 & 2.9 & 30 & 39 & $\therefore$ & 28 & 63 \\
\hline $\begin{array}{l}\text { Mississippi } \\
\text { (Luling Ferry, La.) } \\
\text { (Mean Discharge: } \\
\text { Tarbet Ferry) }\end{array}$ & $17,700^{b}$ & $4,726-21,848$ & 7.3 & 227 & 4.5 & 113 & 2.2 & 51 & $25^{\circ}$ & 0.3 & 21 & 36 \\
\hline $\begin{array}{l}\text { Navidad } \\
\text { (Ganado, Tex.) }\end{array}$ & $14^{\circ}$ & $0.8-600$ & 7.7 & 272 & 18 & 182 & 0.7 & 15 & 49 & & 35 & 55 \\
\hline $\begin{array}{l}\text { Neches } \\
\text { (Evadale, Tex.) }\end{array}$ & $171^{\circ}$ & $13-475$ & 6.9 & 103 & 8.9 & 36 & 0.5 & 15 & 26 & 0.2 & 20 & 10 \\
\hline $\begin{array}{l}\text { Nueces } \\
\text { (Mathis, Tex.) }\end{array}$ & $22^{b}$ & $2.6-300$ & 7.5 & 232 & 13 & .153 & 0.4 & 29 & 31 . & 0.3 & 28 & 47 \\
\hline $\begin{array}{l}\text { Rio Grande } \\
\text { (Rio Grande City, Tex.) } \\
\text { (Mean discharge: } \\
\text { Laredo, Tex.) }\end{array}$ & $123^{b}$ & . & 7.9 & & & 152 & $\therefore$ & 180 & 113 & & 96 & 78 \\
\hline $\begin{array}{l}\text { Sabine } \\
\text { (Ruliff, Tex.) }\end{array}$ & $232^{b}$ & $8.3-501$ & 6.7 & 75 & 12 & 26 & 0.5 & 8.2 & 18 & 0.1 & 14 & 6.9 \\
\hline $\begin{array}{l}\text { San Antonio } \\
\text { (Goliad, Tex.) }\end{array}$ & $16^{\circ}$ & $11-399$ & 8.2 & 619 & 19 & 272 & 9.8 & 109 & 123 & : & 87 & 105 \\
\hline $\begin{array}{l}\text { Son Jacinto (W) } \\
\text { (Conroe, Tex.) }\end{array}$ & $14^{\circ}$ & $6.8-275$ & 7.6 & 186 & 18 & 96 & 0.6 & 5.2 & 47 & & 24 & 36 \\
\hline $\begin{array}{l}\text { Trinity } \\
\text { (Romayor, Tex.) }\end{array}$ & $203^{\circ}$ & $44-1319$ & 7.7 & 245 & 8.2 & 136 & 3.7 & 40 & 37 & $\ldots$ & 36 & 47 \\
\hline
\end{tabular}

- Geological Survey Water-Supply Papers 2120, 2122, and 2123, Surface Water Supply of the United States, 1966-1970, Part F vol. 2, and Part 8, vol. 1 and 2, U.S. Government Printing Office, Washington, D.C., 1975.

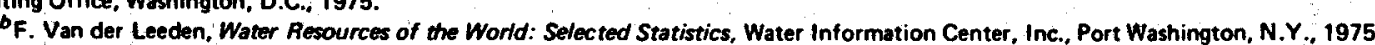

'Geological Survey Water-Supply Papers 2096 and 2097, Ouality of Surface Waters of the United States, 1968, Parts 7 and 8, U.S. Government Printing Office, Washington, D.C., 1973. 
of coastal groundwater sources is given in F1g. 2.6. In Texas, groundwater use comprises $34 \%$ of the state's total water use, while in Louisiana it comprises only $17 \%$. Saline aquifers are apparent along most of coastal Texas and in parts of southern Louislana. Average water temperatures range from $21.1^{\circ} \mathrm{C}\left(70^{\circ} \mathrm{F}\right)$ to $23.7^{\circ} \mathrm{C}\left(75^{\circ} \mathrm{F}\right) .19$

2.4 ECOLOGY

\subsubsection{Terrestria1}

This section describes the natural blological features of the onshore geopressured zones. In many areas, the features described are no longer evident because of agricultural, industrial, urban, or recreational development. Land uses are described in Sect. 2.6 .

The vegetation of coastal Loulsiana and Texas occuples four distinct habitat types: barrier islands, tidal marshlands, river bottoms, and uplands. Long, narrow barrler 1slands line the gulf coast of Texas. These islands range from 1 to 15 miles in width and have foredunes which may reach a height of over $35 \mathrm{ft}$. The dunes are stabilized by the beach morning glory (Ipormoea) and sea oats (Uniola). Behind the dunes, relatively fresh water may accumulate and support rushes (Junious) and various herbaceous species. Other grasses including Andropogon and Panicum may occur in sheltered areas. These barrier islands provide protection for the sea grass beds (ThaZassia) and salt marshes which occur behind them. 


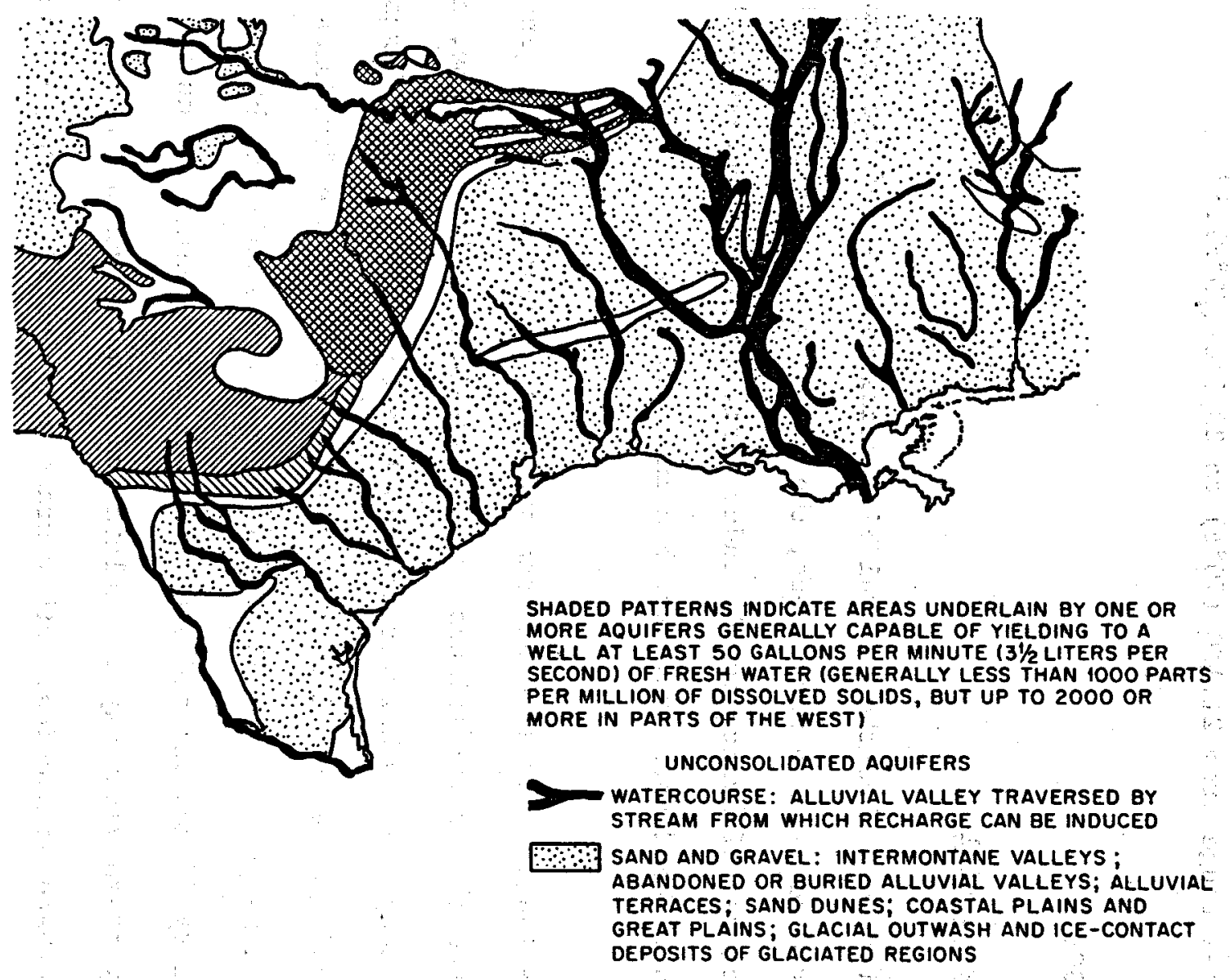

Fig. 2.6. Productive aquifers of the Texas-Louisiana coastal reglons. Source: J. J. Geraghty, D. W. Miller, F. Van der Leeden, and F. L. Troise, Water Atlas of the United States, Water Information Center, Inc., Port Washington, N.Y., 1973. 
Tidal marshes line most of the coast of Louisiana and Texas. These marshes are dominated by salt-tolerant grasses: cordgrass (Spartina alterniflora and S. patens) and needlerush (Juncus). These highly productive marshes support a large number of resident and migratory birds. They also supply large amounts of detritus to estuarine waters, thereby serving as a major energy source for these marine nursery grounds. In southern Texas, high temperatures and low precipitation result in hypersaline conditions which limft the extent and productivity of salt marshes. Where fresh water intrudes into salt marshes, rushes and salt grass (Distichlis) replace the cordgrasses, At the upper edge of salt marshes, freshwater marshes, hypersaline salt flats, salt spray forests of oak, juniper and holly, or a direct transition to the dominant inland vegetation may be found.

The inland vegetation of extreme southern Texas is predominately savanna. The dominant species are blackbrush acacia (Acacia), mesquite (Prosopis), live oak (Quercus), seacoast bluestem (Andropogon), plalns bristle grass (Setaria), and, in some areas, cacti (Oprontia).

Along most of the coast of Texas and western Louisiana, a strip of grassland occurs just inland of the salt marshes. This coastal prairie is dominated by bluestem, coastal sacahulsta (Spartina spartinae), and buffalo grass (Buchlö). This tall-grass prairle occuples h1ghly fertile soil which has been almost entirely converted to agricultural use. 
Evergreen, hardwood, and mlxed upland forests are found inland of the coastal prairle in Louisiana and eastern Texas and in a few areas extend down to the coastal marshes. The composition of these forests is quite variable because of the wide range of climatic and geologic conditions present. The dominant genera are oaks (Quercus), pines (Pinus), and hickory (Carya). A highly diverse mixed mesophytic forest which includes oak, hickory, and pine plus beech (Fagus spp.), sweet gum (Liquidambar styraciflua), southern magnolia (Magnolia) and many other specles occurs In the molster upland areas. The extensive floodplains of the Mississippi, Sabine, Neches and Trinlty rivers are occupied by floodplain forest. The composition of this forest type depends largely on the frequency and duration of flooding. Areas which are regularly flooded support nearly pure stands of bald cyprus (Taxodium). Commonly associated trees are tupelo (Nyssa), red maple (Acer), red bay (Persea), and several species of oak. Less swampy floodplains contain cottonwood (Populus) and willow (Salix). Most of the forests remaining in this region have been subjected to cutting, and many are now intensively managed.

Birds are the most conspicuous members of the coastal and riverine wetland fauna. The barrier 1slands provide nesting sttes for colonies of gulls, terns, skimmers, and brown pelicans. Coastal and riverine marshes are Inhabited by a wide varlety of wading birds including herons, egrets, rails, ibises, and spoonb111. Most North American waterfowl as well as many plovers, wading birds, and sea birds winter in the bays and wetlands 
of thls reglon. The whooping crane, an Important but rare winter resident of the salt marshes, winters on the Texas coast at Aransas. Birds which migrate across the Gulf of Mexico utilize the coastal region for resting and feeding in both the spring and fall. Major wetland mammalian species include muskrat, nutrla, otter, opossum, raccoon, skunk, and numerous small rodents. The red wolf, which once occupled most of the southern United States, is now largely confined to wetlands In southern Louisiana and extreme southeastern Texas.

The mammalian fauna of the coastal prairie, which once included large, herds of bison and pronghorned antelope, is now dominated by smaller animals: coyote, black-tailed Jackrabbit, spotted skunk, and rodents. The remaining uncultivated prairle supplies habltat for the endangered Attwater's greater prairle chicken. Wintering waterfowl feed in the fields and freshwater marshes.

Upland forests support white-talled deer, squirrels, gray fox, rodents, and a large number of specles of passerine birds. The vertebrate fauna Is not genera11y as large or diverse as in other natural vegetations.

The savannas of southern Texas support a mixture of specles from the tropical and temperate regions of North America. Dominant mammals include white-tailed deer, javelina, coyote, nine-banded armadi11o, blacktalled jackrabbit, gray fox, ground squirrels and numerous small rodents. Characterlstlc birds Include the caracara, roadrumner, scaled quall, and 
golden fronted woodpecker. Many specles of animals which are common in Mexico are found irregularly or as small permanent populations in southern Texas.

\subsubsection{Aquatic}

The Gulf of Mexico is the second most productive fishing ground in the world in terms of both value and welght produced. 23 The important commerclal organisms include menhaden, red snapper, black mullet, spotted sea trout, groupers, drums, croakers, pompano, and shrimp (Penaeus). Ninety-seven percent of the commercial catch is dependent on the coastal zone at some stage of 1ts life history. 24 The importance of the coastal zone results from the Input of mineral nutrients and detritus from the rivers and coastal marshes and the high productivity of sea grasses. Sea grass beds (ThaZassia and Zostera) stabilize the bottoms of shallow bays, provide shelter for larval fish and other organisms, and provide food for migratory waterfowl.

Because of the flat topography of this region, saltwater and saltwater fish extend Inland in some places nearly as far as the mapped geopressured resources. Large areas of freshwater habitat do occur in this area including rivers (e.g., Mississippi, Sabine, Atchafalaya, Brazos, Neches, and Colorado), bayous, marshes, 1rrigation canals, and streams. These support a diverse warmwater flshery Including largemouth and spotted black bass, white bass, black and white crapple, carp, paddlefish, and several specles of sunfish, carpsucker, buffalo, gar, catflsh, and sucker. The smaller "forage" fish are both numerous and highly diverse. 


\subsubsection{Endangered species}

Fourteen specles of endangered animals which are found in the Gulf of Mexico geopressured region are listed in Table 2.6. The American alligator has been reduced to the status of a threatened species in the following Louisiana parishes: Cameron, Vermilion, and Calcasieu. The U.S. FIsh and Wildlife Service Is currently conslderlng the same reduction in status for alligators in much of the rest of their range. The most recent 11st of endangered animals deletes the tule white-fronted goose (Anser albiforns gambelli) and adds the Mexican duck (Anus diazi) and a subspecies of grey wolf (Canis Zupus monstrabilis) which may be found in South Texas. 25

There is currently no national 11st of threatened or endangered plants. A 1ist of plants under consideration for these designations has been published by the Department of the Interior. 26 This 11st includes 95 possible endangered species and 135 possible threatened species for the State of Texas, as well as one possible endangered species and eight possible threatened species for the State of Loulsiana. The occurrence of these species will be determined on a oite-specific basis for individual geothermal projects.

\subsection{WATER USE}

A strong gradient in water avallabllity occurs across the geopressured region; there is a large water surplus In the Mississippi Valley and a large water deficiency in southern Texas. The boundary between water 
Table 2.6. Threatened wildifo whose range is expected to extend within the Gulf of Mexico geopressured region

Rare and endangered species - species regatded as threatened with extinc

tion because of habitat destruction, disease, or predation, whose survival requires assistance.

American alligator (Alligator mississipiensis)

Red wolf (Canis rutus)

Brown pelican (Pelecanus occiden talis carolinensis)

. Eskimo curlew (Numenius borealis)

Tule white-fronted goose (Anser albifoms gambelli)

Bald eagle (Haliaeetus I. leucocephalus)

American peregríne falcon (Fa/co peregrinus anatum)

Arctic peregrine falcon (Falco peregrinus tundrius)

Attwater's greater prairie chicken (Tympanuchus cupido attwateri)

Whooping crane (Grus ámericano)

Mississippi sandhill crane (Grus canadensis pulla)

Red-cockaded woodpecker (Dendrocopos borealis)

Ivory billed woodpecker (Campephilus p. principalis)

Bachman's warbler (Vermivora bachmanii)

1. Status peripheral - species at the edge of their natural range and

threatened with extinction within the United States.

Chihuahua shiner (Notropis chichuahua)

Rio Grande darter (Etheostome grahami)

Jaguar (Felis onca veraecrucis)
Jaguarundi (Felis yagouaroundi cacomitli)

Ocelot (Felis pardalis albescens)

Margay (Felis wiedii cooperi)

Northeastern least grebe (Podiceps dominicus brachypterus)

Sennett's white-tailed hawk (Buteo albicaudatus hypospodius)

Northern gray hawk (Buteo nitidus moximus)

Northern black hawk (Buteogallus a. anthracinus)

Northern chachalaca (Ortalis vetula mccalli)

Northern jacana Nacana s. spinosa)

Reddish egret (Dichromanassa r. rufescens)

Roseate spoonbill (Ajaia aja)

Northern black-bellied tree duck (Dendrocygna autumnalis fulgens)

Masked duck (Oxyura dominica)

Northern red-billed pigeon (Columba f. flavirostris)

Northern white-fronted dove (Leptotila verreauxi angelica)

Northern groove-billed ani (Crotophaga \&. su/cirostris)

Ferruginous owl (Glaucidium brasilianum)

Northern buff-bellied hummingbird (Amazilia yucatanensis chalconota)

Northeastern elegant trogon (Trogan elegans ambiguus)

Northeastern green kingfishes (Chloroceryle americans sextentrionalis)

Northeastern rose-throated becard (Platypsaris aglaiae gravis)

Northern beardless flycatcher (Camptostoma i. imberbe)

Northern green jay (Cyanocorax yncas fuxuous)

Northern olive-backed warbler (Parula pitiayumi nigrilora)

Alta Mira Lichtenstein's oriole (/cterus gularis tamaulipensis)

Audubon's black-headed oriole (Icterus graduacauda audubonii)

Northern white-collared seedeater (Sporophila torqueola sharpei)

Northern olive sparrow (Arremonops r. nufivirgata)

Northeastern Botteri's sparrow (Aimophila botterii texana)

Status undetermined - species suggested as possibly threatened with extinction within the United States.

Guadalupe bass

Louisiana vole (Microtus /udovicianus)

Wood ibis (Mycteria americana)

Osprey (Pandion haliaetus carolinensis)

Mountain plover (Eupoda montana)

Northern long-billed curlew (Numenius americanus parvus)

Eastern pigeon hawk (Falco c. columbarius)

Source: Office of Endangered Species and International Activities, Threatened Wildife of the United States, Resource Publication 114 Bureau of Sport Fisheries and Wildlife, U.S. Department of the Interior, Washington, D.C., 1973. 
surplus and deficit occurs at approximately, the center of the Gulf Coast of Texas near Matagorda Bay, 19

Water rights in Loulsiana are primarlily associated with land ownership (riparian rights). Because of the abundance of water across the state, most water projects have been concerned with dratnage or flood control. rather than increasing the supply. Thus, there have been relatively few legal conflicts over water supply and little need for appropriative rights (rights from use). In 1970 , only $17 \%$ of total water withdrawals were from groundwater. 19

The aridity of much of Texas has led to the extensive regulation of water resources by the construction of dams and canals, While Texas has traditionally recognized both riparian and approprlative rights, increased water regulation and distribution has led to increasing predominance of approprlative rights, Most of the reservoirs are inland of the geopressured zone. While they have decreased the totar water flow through the coastal region, the reservolrs have made the coastal flow more rellable Surface water use is becoming more important relative to groundwater use in coastal Texas as $1 \mathrm{t}$ has In the rest of the state (groundwater pumpage expressed as a percentage of total water use declined from 58 to $34 \%$ between 1960 and 1970), 19,27 Because groundwater pumpage has resulted in land surface subsidence and saline water intrusion, the Texas Water Development Board has recently, reduced their estimate of water avallability in the Gulf Coast aquifer from $2,361,000$ to $1,143,400$ acre-ft/year. 28 Although water 1 s subject to heavy 
municipal and Industrial use, the greatest use has been for agricultural irrigation. The shortage of low-salinity water in this region has already led to the construction of desalinization plants of over 1,000 gal/day capacity at Texas C1ty and Freeport, Texas.

\subsection{LAND USE AND REGIONAL DEMOGRAPHY}

\subsubsection{Land use}

Principal land uses in the Texas-Loulstana geopressured region are agriculture, petroleum and natural gas production, and, in coastal areas, relatively unused marshland. Primary agricultural uses are rice and truck farming. Cotton is the major crop in the southern Texas area. Pasture, range, and hay flelds are important for beef production in many counties.

Much of the geopressured region has seen large-scale petroleum and natural gas field development. Drilling rigs have been a common part of the landscape in many areas for the last 70 years. Abandoned fields with derricks and pumps st111 present are not uncomon. A great deal of production is st1ll going on and w11l continue for sometime.

Table 2.7 shows land use acreages by principal land use categorles for representative cointies (parishes) in the geopressure reglons of Louistana and Texas. Only a small percentage of the land in these counties is federally owned. The only large Federally owned parcels are national wildlife refuges along the coast (Aransas, Sablne, Lacassine, 
Table 2.7. Land use summary for representative counties

Conservation needs inventory based on 1967 data - acreage per county

\begin{tabular}{|c|c|c|c|c|c|c|c|c|c|c|c|}
\hline County & Federal & $\begin{array}{l}\text { Percent } \\
\text { Federal }\end{array}$ & Urban & $\begin{array}{l}\text { Row } \\
\text { crop }\end{array}$ & $\begin{array}{l}\text { Other } \\
\text { cropland }\end{array}$ & Orchard & Pasture & Range & Forest & Other & $\because$ Total \\
\hline$\because \therefore \quad \cdots$ & 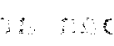 & 851 & $\because 2$ & $\therefore=2$ & & 8. & $\because$ & $\because \div$ & 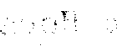 & $\therefore$ & $-1<$ \\
\hline ension & 0 & 0 & 10,550 & 32,015 & 9,192 & 0 & 43,468 & 0 & 92,992 & 1,513 & 192,000 \\
\hline ron. & 128,241 & 15 & 8,993 & 3,390 & 99,734 & 50 & 39,781 & 250,000 & 1,560 & 286,061 & 849,211 \\
\hline & 5,525 & 1 & 11,249 & 61,089 & 26,158 & 0 & 19,994 & 0 & 123,396 & 118,953 & 377,654 \\
\hline ille & 395 & 0 & 8,575 & 32,948 & 22,813 & 1,160 & 45,174 & 0 & 277,973 & 5,104 & 401,920 \\
\hline che & 0 & 0 & 10,568 & 68,223 & 16,619 & $\begin{array}{r}0 \\
20\end{array}$ & 22,741 & 24,927 & 150,875 & 431,632 & 739,785 \\
\hline larles & 0 & 0 & 7,000 & 12,480 & 891 & 0 & 2,475 & 0 & 81,714 & 78,742 & 193,302 \\
\hline mes & $\mathbf{0}$ & 0 & 3,803 & 59,194 & 967 & 0 & 4,297 & 0 & 85,500 & 4,739 & 159,360 \\
\hline artin & 0 & 0 & 4,827 & 53,420 & 30,228 & 200 & 26,059 & 0 & 348,153 & 12,680 & 483,304 \\
\hline sonne & 117 & 0 & 12,717 & 43,869 & 4,539 & 0 & 15,010 & 26,227 & 122,300 & 605,265 & 890,240 \\
\hline rmilion & 30 & $=0$ & 18,236 & 19,599 & 277,981 & 0 & 50,094 & 70,537 & 30,051 & 298,007 & 783,360 \\
\hline & & & & & & & & & & & \\
\hline isas & 46.942 & 27 & 5,503 & 4,695 & 783 & 0 & 587 & & 9,584 & 31,296 & 173,184 \\
\hline & 1,809 & $\mathbf{0}$ & 22,287 & 104,785 & 9,740 & 0 & 31,941 & 359,926 & 5,064 & 2,728 & 538,880 \\
\hline oria & 0 & 0 & 81,000 & 39,000 & 228,003 & 803 & 228,371 & 148,719 & $-176,281$ & 8,032 & 910,784 \\
\hline un & 18,624 & 5 & 9,066 & 60,819 & 43,748 & 0 & 17,222 & 167,004 & 0 & 30,688 & 337,216 \\
\hline val & 0 & 0 & 8,865 & 69,356 & 0 & 0 & 25,130 & $1,047,796$ & $\mathbf{0}$ & 9,192 & $1,160,414$ \\
\hline d & 0 & $\mathbf{0}$ & 4,809 & 41,258 & 23,742 & 0 & 13,282 & 264,985 & 195,083 & 13,281 & 557,440 \\
\hline rdin & 0 & 0 & 18,874 & 416 & 8,317 & 0 & 30,669 & 0 & 501,600 & 13,724 & 573,800 \\
\hline algo & 1,984 & $\mathbf{0}$ & 64,457 & 402,201 & 48,168 & 63,784 & 34,674 & 345,560 & 0 & 25,909 & 987,328 \\
\hline edy & 0 & 0 & 3,228 & 1,810 & 1,500 & 0 & 9,517 & 737,318 & 0 & 138,609 & 892,032 \\
\hline berg & 4,161 & 1 & 9,048 & 48,139 & 2,788 & 0 & 15,532 & 430,582 & 0 & 34,251 & 544,576 \\
\hline tagorda & 0 & 0 & 16,761 & 35,033 & 250,366 & 0 & 140,355 & 187,278 & 96,841 & 14,079 & 740,736 \\
\hline leces & 4,539 & 1 & 77,038 & 313,570 & 27,399 & 0 & 27,019 & 49,850 & 0 & 41,478 & 540,992 \\
\hline pata & 19,352 & 3 & 4,257 & 6,475 & 9,001 & 0 & 3,519 & 610,835 & 0 & 2,158 & 655,872 \\
\hline
\end{tabular}

Source: U.S. Department of Agriculture, Soil Conservation Service, Texas and Louisiana Soil and Water Conservation Needs Inventory, 1969.

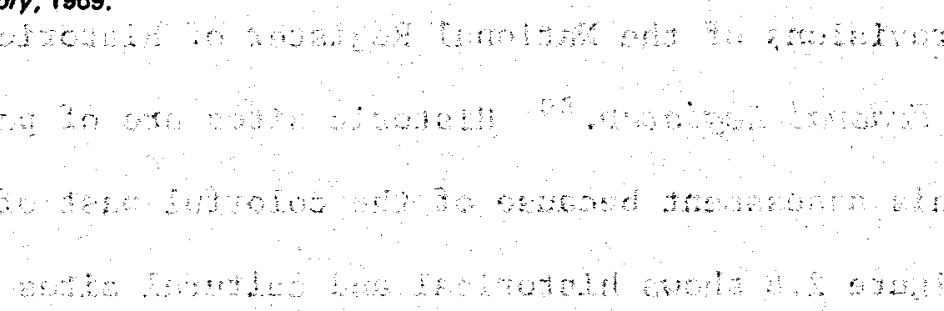


and Delta) and national forests inland (Sam Houston, Davy Crockett, Angelina, Sabine, and Fort Polk).

\subsubsection{Demography}

Population distribution throughout the geopressure region ranges from very sparse to dense. Figure 2.7 shows urban and rural population distribution in Loulsiana and Texas. Several large urban areas are apparent. The Houston area is one of the fastest growing urban areas In the United States, whereas the city of New Orleans declined In population between the 1960 and 1970 censuses.

Table 2.8 gives population densities for representative counties (parishes) within the geopressure region and lists all citles with population greater than 20,000 .

\subsection{REGIONAL HISTORIC, SCENIC, CULTURAL AND NATURAL FEATURES}

The National Atlas ${ }^{29}$ provides historical and cultural information about the United States. Prehistoric sites and cultural complexes are also described. Cumulative revisions of the National Register of Historic Places are given in the Federal Register. ${ }^{30}$ Historic sites are of particular significance to this assessment because of the colorful past of Loulstana and Texas. Figure 2.8 shows historical and cultural sites and natural landmarks in the geopressure region of Texas and Louisiana. Scenic and natural features are given in the National Registry of Natural Landmarks, which appears in the Federal Register. 31 
ES-2983
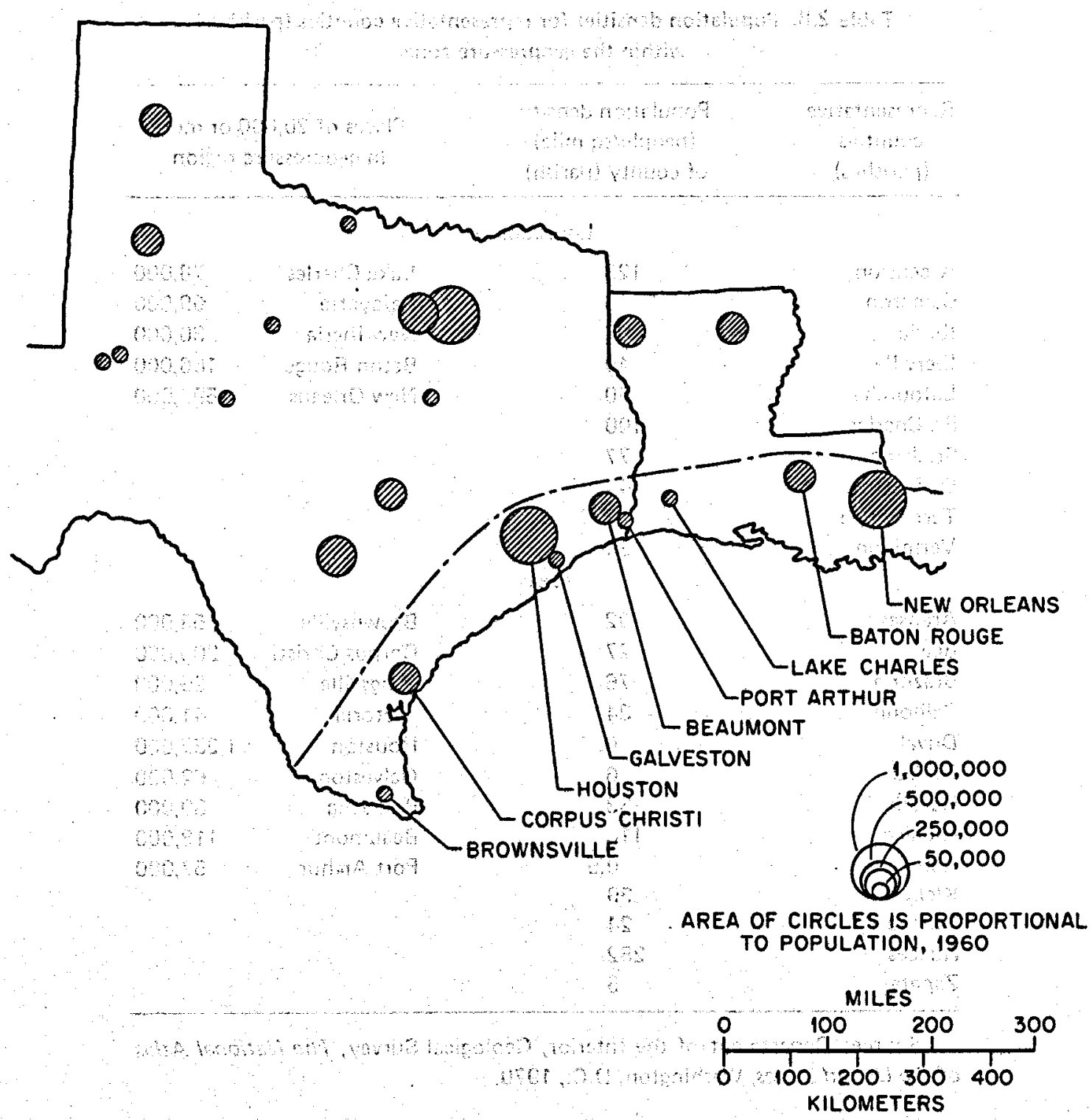

Fig. 2.7. Population distribution in Louisiana and Texas, Source: U.S. Department of the Interior, Geological Survey, The National Atlas of the United States, Washington, D.C., 1970. 
Table 2.8. Population densities for representative counties (parishes) within the geopressure zone

\begin{tabular}{|c|c|c|c|}
\hline $\begin{array}{c}\text { Representative } \\
\text { counties } \\
\text { (parishes) }\end{array}$ & $\begin{array}{l}\text { Population density } \\
\text { (people/sq mile) } \\
\text { of county (parish) }\end{array}$ & $\begin{array}{l}\text { Places of } 20,0 \\
\text { in geopressu }\end{array}$ & $\begin{array}{l}\text { Dor more } \\
\text { region }\end{array}$ \\
\hline \multicolumn{4}{|c|}{ Louisiana } \\
\hline Ascension & 123 & Lake Charles & 78,000 \\
\hline Cameron & 6 & Lafayette & 69,000 \\
\hline Iberia & 97 & New Iberia & 30,000 \\
\hline Iberville & 49 & Baton Rouge & 166,000 \\
\hline Lafourche & 60 & New Orleans & 593,000 \\
\hline St. Charles & 100 & & \\
\hline St. James & $: 77$ & & \\
\hline St. Martin & 44 & & \\
\hline Terrebonne & 56 & & \\
\hline Vermilion & 36 & & \\
\hline \multicolumn{4}{|c|}{ Texas } \\
\hline Aransas & 32 & Brownsville & 53,000 \\
\hline Bee & 27 & Corpus Christi & 205,000 \\
\hline Brazoria & 76 & Kingsville & 29,000 \\
\hline Calhoun & 34 & Victoria & 41,000 \\
\hline Duval & 6 & Houston & $1,232,000$ \\
\hline Goliad & 6 & Galveston & 62,000 \\
\hline Hardin & 33 & Pasadena. & 89,000 \\
\hline Hidalgo & 118 & Beaumont & 118,000 \\
\hline Kenedy & 0.5 & Port Arthur & 57,000 \\
\hline Kleberg & 39 & & \\
\hline Matagorda & 24 & & \\
\hline Nueces & 282 & & \\
\hline Zapata & 5 & & \\
\hline
\end{tabular}

Source: Department of the Interior, Geological Survey, The National At/as of the United States, Washington, D.C., 1970. 
ES-2985

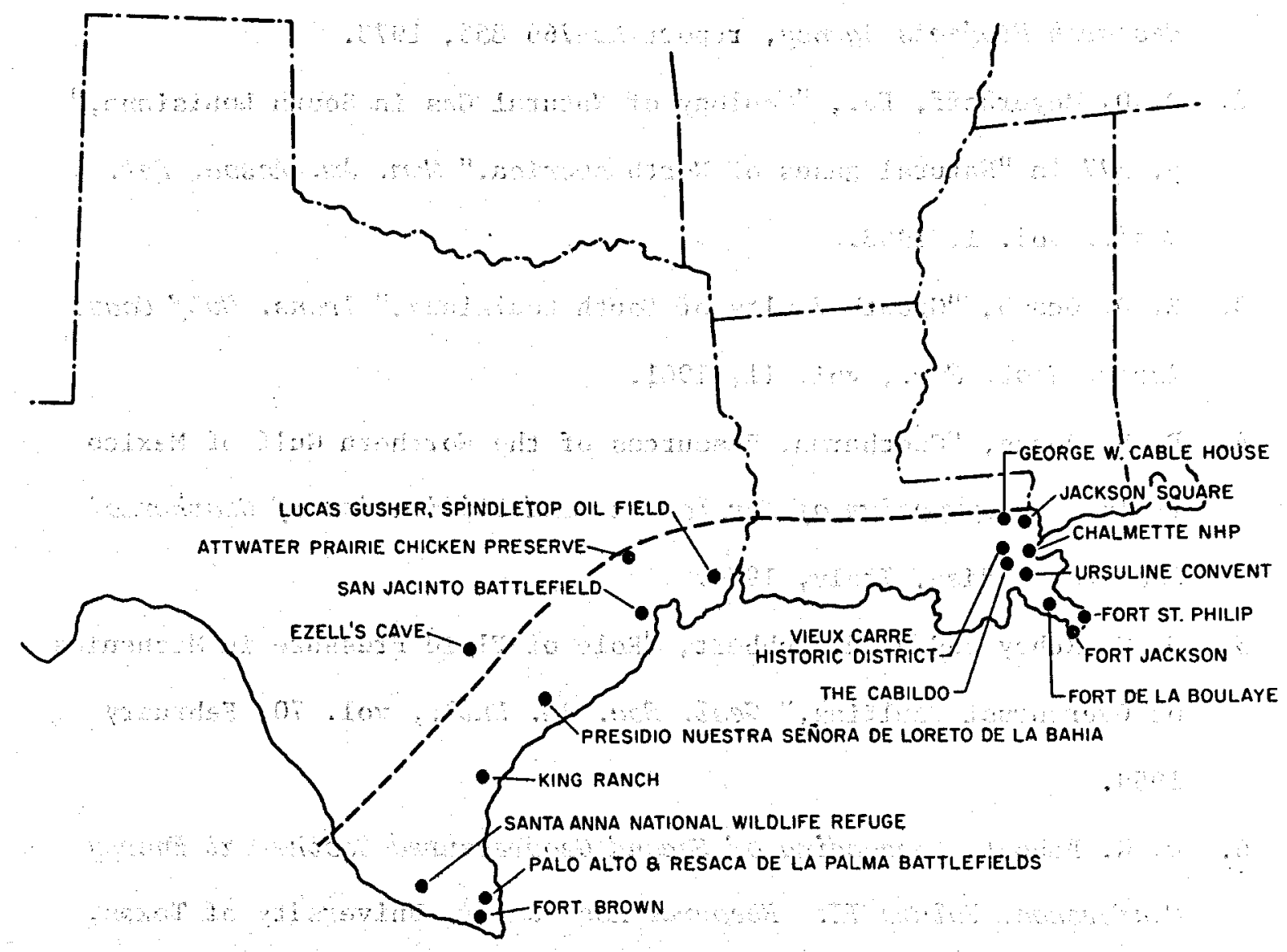

Fig. 2.8, Historic sites and landmarks and natural landmarks. Source: U.S. Department of the Interior, Geological Survey, The National Atlas of the United States, Washington, D.C., "Reg1stry of Natural Landmarks," Fed. Regist. 38(171) 23890-23895 (Sept. 1973). 
REFERENCES FOR SECTION 2

1. E. Herrin, "Development of Geothermal Reservoirs from Over-Pressured Areas Beneath the Gulf Coastal Plain of Texas, A Feasibility Study of Power Production from Over-Pressured Reservo1rs," Advanced Research Projects Agency, report AD-766 855, 1973.

2. D. D. Meyerhoff, Ed., "Geology of Natural Gas In South Loulsiana," p. 377 in "Natural gases of North America," Mem. Am. Assoc. Pet. Geol., vol. 1, 1968.

3. R. D. Ocamb, "Growth Faults of South Loulsiana," Trans. Gulf Coast Assoc. Geol. Soc., vol. 11, 1961.

4. P. H. Jones, "Geothermal Resources of the Northern Gulf of Mexico Basin," UN Symposizm of Development and Utilization of Geothermal Resources, Pisa, Italy, 1970.

5. W. W. Rubey and M. H. Hubbert, "Role of Fluid Pressure in Mechanics of Overthrust Faulting," Geol. Soc. Am. BuZZ., vol. 70, February 1959.

6. D. G. Bebout, Proceeding of Second Geopressured Geothermal Energy Conference, Volume II: Resource Assessment, University of Texas, Austin, February 1976.

7. M. Dorfman and R. 0. Kehle, "Potential Geothermal Resources of Texas," Geological Circular 74-4, Bureau of Economic Geology, University of Texas, Austin, 1974.

8. G. W. Schmidt, "Interstitial Water Composition and Geochemistry of Deep Gulf Coast Shales and Sandstones," Amer. Assoc. Pet. Geol. BulZ., vol. 57, February 1973. 
9. S. S. Papadopulas, R. H. Wallace, Jr., J. B. Wesselman, and

R. E. Taylor, "Assessment of Onshore Geopressured-Geothermal

Resources in the Northern Gulf of Mexico Basin," Geological Survey Circular 726, 1975.

10. M. H. Dorfman and R. W. Deller, Proceedings of Second Geopressured Geothermal Energy Conference, Volume I: Sumary and Future Projections, University of Texas, Austin, February 1976.

11. I. H. Milne and J. W. Early, "Effect of Source and Environment on Caly Minerals," Am. Assoc. Pet. Geol. BulZ,, vol. 42, 1958.

12. G. Dickinsen, "Geological Aspects of Abnormal Reservoir Pressures in Gulf Coast Loulsiana,"Amer. Assoc. Pet. Geol. BulZ., vol. 37, February 1953 .

13. K. Magara, "Compaction, Ion Filtration, and Osmosis in Shale and Their Significance In Primary Migration," Am. Assoc. Pet. GeoZ. Bulz., vol. 58, February 1974 .

14. M. F. Halbouty, Salt Domes - Gulf Region, United States and Mexico, Gulf Publishing Company, Houston, Texas, 1967.

15. M. P. Billings, Structural Geology, Prentice-Hall, Inc., Englewood C11ffs, New Jersey, 1972.

16. Department of the Interfor Geological Survey, The National Atlas, Washington, D.C., 1970.

17. R. B. Orton, "The Climate of Texas," Climates of the States: Volume II - Western States, National Oceanic and Atmospheric Administration, Water Information Center, Inc., Port Washington, N.Y., 1974. 
18. R. Sanders, "The Climate of Louistana" In Climates of the States: Volume II - Westerm States, National Oceanic and Atmospheric Administration, Water Information Center, Inc., Port Washington, N.Y., 1974 .

19. J. J. Geraghty, D. W. M11ler, F. Vander Leeden, F. L. Tro1se, Water Atzas of the United States, Water Information Center, Inc., Port Washington, N.Y., 1973.

20. B. B. Barrett, Cooperative Gulf of Mexico Estuaries Inventory and Study, Louisiana-Phasè II, Hydrology, Louisiana Wildilfe and Fisheries Commission, New Orleans, 1971.

21. D. K. Todd, Ground Water Hydrology, Wiley, New York, 1964.

22. R. D. Price, D. D. Muller, and W. B. Klemt, "Reevaluation of State's Groundwater Resources Completed" In Water for Texas, February 1976.

23. J. L. Taylor, D. L. Felgenbaum, and M. L. Stursa, "Utilization of Marine and Coastal Resources," A Summary of Knowledge of the Eastern Gulf of Mexico, 1973, P. IV-1.

24. Gordon Gunter, "Some Relationships of Estuaries to the Fisheries of the Gulf of Mexico" Pp. 621-638 in Estuaries, G. H. Lauff, Ed., AAS Pub1. 83, Washington, D.C., 1967.

25. U.S. Department of the Interfor, "Endangered and Threatened Wild1ife and Plants, Republication of the List of Species," Fed.. Regist. 41(208) (1976).

26. U.S. Department of the Interior, "Threatened or Endangered Fauna or Flora, Review of Status of Vascular Plants and Determination of Critical Habitat," Fed. Regist. 40(127) (1975). 
27. D. W. Miller, J. J. Geraghty, and R. S. Collins, Water Atlas of the United States, Water Information Center, Inc., Port Washington, N.Y., 1963.

28. R. D. Price, D. A. Muller, and W. B. Klemt, 1976, "Reevaluation of State's Groundwater Resources Completed," Water for Texas 6: 11-15.

29. U.S. Department of the Interior, National AtZas of the USA, Geological Survey, 1970.

30. "National Reglster of Historic Places," Fed. Regist. 40(24): 5242-345 (1975) (and updates first Tuesday of each month).

31. "National Registry of Natural Landmarks," Fed. Regist. 39(112): 20405-56 and $39(203): 37225-26$ (1974). 
3. DESCRIPTION OF GEOPRESSURE RESOURCE DEVELOPMENT AND UTILIZATION

Although abnormally pressured fluids are present in several parts of the United States, ERDA has chosen the Louisiana and Texas coastal areas to prove the technology for the development of the geopressured resource. The emphasis of ERDA-supported programs will be directed to onshore geopressure aquifers, but the technology developed can be used by the geopressured Industry for offshore as well as onshore applications. Deriving energy from geopressured resources involves resouce development and resource utilization. Resource development includes all activities associated with the location and characterization of the geopressured resource. Resource utilization involves construction and operation of systems designed to convert geothermal energy to a suitable form and to distribute the energy to end users. Activities discussed in the followIng sections are generally applicable to test facilities, pllot plants, demonstration plants, and commercial plants.

\subsection{RESOURCE DEVELOPMENT:}

Resource development includes resource exploration and assessment, well drilling, well testing, and fleld development. The objectives of these activities is to identify the geopressured reservoirs, to determine the extent and head centers of the reservoir, and to determine the chemical and thermodynamic properties of the fluid. 


\subsubsection{Exploration}

The Texas and Louislana coast has been extensively drilled for ofl and gas which has provided much detalled information on the geological and geophysical characteristics of the area. Detalled analysis of existing data will indicate the nature and distribution of the Gulf coast onshore geopressured aquifers and will reduce the need for exploration activities Involving geochemical and geophysical techniques.

In a geopressured aquifer the subsurface fluid pressure significantly exceeds that of normal hydrostatic pressure. Regional studies, welllog data, correlation of well logs, and determination of fairways are steps Involved in assessing the resource. Regional studies locate broad areas where geopressured zones may exist by the analysis of electric logs and geologic cross sections from the deepest wells drilled in the region. Acquisition of well logs from wells spaced five to ten miles apart provides a basis for the correlation of formation cross sections and for the construction of geological and isothermal maps. Electric logs from closely spaced wells coupled with micropaleontological studies provide the basic correlation grid necessary for locating geopressured reservolrs. In addition, well logs providing detalls on the drilling mud weight, the location of the intermediate casing point, the density and resistivity of shale, and bottom-hole temperatures are used to indicate geopressured zones. The top of the geopressured zone can be calculated from well-log data, and geothermal falrways can be Identified. 
The above activities are not onsite activities when existing well logs are used.

\subsubsection{Test drilling and production testing}

The completion technology for geopressured wells has not been well defined. The geopressured well must be completed to deliver the highvolume rates needed for economic power plant generation at a velocity low enough to avoid excessive abrasive action of sand grains in the production stream. In general, it has been assumed that the drilling requirements will be simflar to those for hydrothermal well drilling.

Drilling wells that penetrate the geopressured zone is more difficult than drilling wells to the same depth in normally-pressured formations. The placement of the intermediate casing is critical, and high pressures and temperatures require extra care and expense in maintaining the drilling mud system. Completion equipment, logging instrumentation, and other down-hole tools may require spectal attention due to increased temperatures and pressures. The drilling and testing of geopressured geothermal wells w111 provide the experience necessary to determine optimal designs. Test driliing includes site preparation, drilling operatione, well testing, and well abandonment. 


\subsubsection{S1te selection and preparation}

In determining the specific site for a geopressured geothermal well, all avallable offset wells are studied to determine the geologic section to be drilled and the characteristics of the formations to be penetrated. If necessary, subsurface features can be further Identified by seismic studies. Other factors that influence site selection include legal boundaries, the potential for environmental Impacts, and accessibility, that is, the amount of road and site preparation required.

Road construction, drill-pad construction, reserve pond construction, and construction of a disposal system for large quantities of geothermal fluid are the major surface activities involved in drill-site preparation. Roads will be semipermanent and designed to function year-round, to withstand a constant traffic burden, and to carry heavy drilling equipment. New road cuts will be required where existing roads and trails cannot be upgraded. In hilly terrain, cut-and-f1ll construction may be required, which will result in changes in land features and extensive removal of vegetation. A means for controlling erosion and siltation due to surface runoff will be provided. Disturbance of vegetation on and adjacent to road cuts is unavoldable. Surfacing the road with rock, gravel, volcanic cinders, or other surface treatments will maintain the road in satisfactory condition. Assuming that an average of $3.2 \mathrm{~km}$ (two miles) of new or improved roads per well 1 s required and that roads will be $6.1 \mathrm{~m}(20 \mathrm{ft}$ ) wide, about 2 ha (five acres) of land per well will be disturbed by road construction. 
Dril1-pad construction requires that an area of about 0.4 to 0.8 ha (one to two acres) be levelled and cleared of vegetation. The pad area will provide space for the drilling rig and accessorles, temporary structures, parking, and maneuvering room for service and delivery vehicles. The pad may be surfaced with rock or gravel.

A reserve pond of several square meters to several hundred square meters (several hundred to several thousand square feet) in area and 1 to $3 \mathrm{~m}$ (5 to $10 \mathrm{ft}$ ) deep, depending on the depth of the hole, will contain waste fluids and drill cuttings. The pond will be lined with impervious material to reduce leaching and groundwater contamination.

Large quantities of geothermal fluld will be discharged from the well during testing. A means for disposal will be designed and constructed. Site preparation may include preparing a second drill pad in the site vicinity for drilling a reinjection well, construction of an evaporation pond, or construction of a drainage system to convey the fiuld to the ocean or other surface discharge. Drilling of a reinjection well will be simflar to drilling a production well if an abandoned production well is not avaliable. Construction of an evaporation pond or drainage system will require clearing, grading, and excavation. Evaporation ponds may not be an acceptable means for the disposal of geothermal fluids in some states. Ponds and drainage channels will be designed with Impervious material to contain the fluid and prevent groundwater contamination. 
During the above phases of site preparation, construction activity will alter the topography over the affected area, increase notse levels, reduce air quality as a result of fugitive dust and operation of gasoline-powered vehicles, and destroy vegetation resulting in increased exposure of the soll to wind and water. Portable sanitary facilities w111 be provided for construction crews, and construction wastes w111 be disposed of at suitable spoil sites.

\subsubsection{Drilling requirements}

Drilling operations require drilling equipment, support facilities, and manpower support. The largest plece of equipment is the drilling rig. Drilling accessories include the power supply, mud pumps, air compressors, pipe rack, drill bits, mud pit, and a cooling tower. In addition, fuel tanks, water tanks, a reserve pond, and temporary structures for offices, locker rooms, and storage areas are required at the drill site. The quantity of water required will depend on depth of the well and specific site conditions. Water may be obtained from a well, from a local stream, or delivered to the site and stored, depending upon its availability. All other commodities w1ll be delivered and stored onsite.

Approximately 6 to 15 persons may be present on the site at any particular time. The required personnel can be categorized as continuing personnel or intermittent personnel. Continuing personnel include drilling crews, logging geologists, drilling supervisors, and a rig superintendent. This group usually operates the drilling rig around the clock, but abbreviated schedules are sometimes observed to reduce 
nolse. The intermttent personnel include truck drivers delivering vartous supplies; service personnel spectalizing in such areas as cementing, down-hole surveys, or formation evaluation tests; and various inspectors. The intermlttent personnel are only required at certain stages of the drilling operation. Potable water and sanitary facilities for personnel assoclated with drilling activities will be provided.

The time required to drill a well will depend on the depth of the hole. A geopressured geothermal well generally ranges in depth from 1.5 to $4.6 \mathrm{~km}$ (5,000 to $15,000 \mathrm{ft})$. T1me requirements may increase because of delays caused by mechanical problems, Inclement weather, supply shortages, and reduced hours observed to control environmental or soctetal impact.

A typical drilling arrangement for geothermal development is shown in Fig. 3.1. Rotary drilling, the most common drilling method, requires a changeable bit, a drill pipe, and a drilling fluid system. Wells plercing a geopressured reservoir are generally deeper than wells drilled for hydrothermal reservoirs and, therefore, may require larger drilling rigs. The drilling fluld is usually a mixture of water, clay, chemfcal, and wefght additives called drilling mud. The drilling mud is circulated down the drill pipe and up the open area outside the pipe to cool and lubricate the bit, remove cuttings from the hole, and seal off the penetrated formations. The weight of the mud helps keep formation pressures under control and forms a wall cake on the inside of the hole which helps prevent sloughing of the hole sides. The drilling mud 




Fig. 3.1. Diagram of typical drilling arrangement in geothermal development. Source: U.S. Dept. of the Interior, Final Environmental Statement for the Geothermal Leasing Program, vol. 1, Washington, D.C., 1973. 
density required to control the high pressures associated with geopressured reservolrs may be up to 2.2 to $2.4 \mathrm{~kg} / 1$ (18 to $201 \mathrm{~b} / \mathrm{gal}$ ), which is much greater than the mud density required for drilling hydrothermal wells. Mud is recirculated and cooled in mud tanks, and the cuttings are removed and stored in the reserve pond. The reserve pond is also avallable for withholding excess mud from the system.

At various stages during drilling and before casing, the drill pipe is removed and evaluation logs are run. Log measurements include such parameters as resistivity, conductivity, sonic response, and response to the radioactivity of varlous layers of rock. The logs provide information on rock types and formation flufds penetrated by drilling.

Effluents during drilling include air pollutants from the operation of motor vehicles and diesel-powered equipment, dust from movement of vehicles on untreated surfaces, noise, and fluids contained in the reserve pond. The fluids may Include accidental or incldental spills of fuel, lubricants, or other substances; runoff from the drill-pad area; and excess muds not contained in the mud pits. In addition, drill cuttings from mud drilling are contained in the pond. Leaching and groundwater contamination are prevented by an Impervious lining in the pond. The reserve pond contents will be solidified and burled after drilling completion. During well testing, the reserve pond will be used for storage of geothermal fluids if necessary. The reserve pond will be filled and levelled after drilling and testing, and the drill site area will be 
reseeded. The effects of deep-well drilling are generally confined to the well-site area.

Environmental hazards during drilling include the possibility of geothermal fluid movement in the well bore within various zones or layers and the possibility of a blowout. All well holes will be cased, and the casing will be cemented from the earth's surface to the production zone. Cemented casings protect freshwater zones, Isolate different production zones, keep the hole from sloughing 1n, protect the pipe from corrosive fluids, and ensure control of well pressure. A typical casing program would consist of a conductor casing 15 to $60 \mathrm{~m}$ (50 to $200 \mathrm{ft}$ ) deep, a surface casing set between 60 and $400 \mathrm{~m}(200$ and $1,300 \mathrm{ft})$ to anchor blowout equipment, an intermediate casing to protect interlying zones and maintain zone separation, and a production casing. ${ }^{1}$ The setting of intermediate casings is critical in geopressured wells because of the mud weights required to control the formation. Normally-pressured formations may break down due to excessive mud pressures if intermediate casings are placed at too shallow a depth. The number of casing strings required will vary with depth of the well and various formation zones. Each casing w111 be cemented in place and w11l overlap $30 \mathrm{~m}(100 \mathrm{ft})$ to ensure that geothermal fluids do not leak from the producing zone to overlying aquifers. Cementing is accomplished by filling the annular area between the pipe and formation with cement up to the earth's surface. The type of material used in cementing depends on temperature, pressure, and formation conditions. 
A blowout can occur if the pressure of the penetrated formation exceeds the pressure exerted by the colum of fluid in the hole or if improper casing sealing or overlap is provided. Steam, hot water, methane, and fluid contaminants $\left(\mathrm{CO}_{2}, \mathrm{NH}_{3}\right.$, possibly $\left.\mathrm{H}_{2} \mathrm{~S}\right)$ may be vented to the surface as a result of a blowout. Fire is also a potential hazard associated with blowouts from geopressured wells due to the presence of methane gas. Effluents from a blowout include increased noise levels, gaseous emissions, and geothermal fluids. These effluents w11l be discussed in detail in Sect. 3.2.1.3. Blowout preventers and related control equipment are installed, tested, and maintained to prevent such occurrences. Equipment w11l be rated at the maximum pressures expected from the reservoir. The probability of blowout occurrence can be reduced as a result of technological refinements.

\subsubsection{Well testing}

The logging program for a geothermal test well is designed to provide information for predicting the overall well performance. Flow, stabillty of well bore, composition and temperatures of geothermal fluids, and assoctated pressures are examples of the Information obtained. A baseIne condition is established at the beginning of the test period, and tests are repeated to establish changes in the baseline.

Hydraulic fracturing may be required to increase the productivity of a geopressured well by removing the formation damage caused by drilling

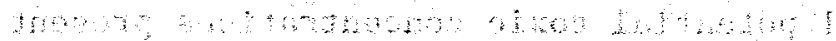


and cementing operations and by stimulating the in situ producing capacity of the reservoir. In the hydraulic fracturing technique, the reservolr rock is subjected to a force capable of producting deep, highly conductive fractures within the reservoir. The fractures reduce the distance that reservolr fluids must travel to reach the low-pressure condition found at the well bore. Propping agents deposited during fracturIng operations hold open the fracture that the earth's forces tend to close. Propping agents sultable for use in geopressured aquifers are yet to be developed.

During well testing the well is vented to the surface, causing noise and the release of geothermal effluents. Noise may be abated by venting through a muffler system. The geothermal flow to the surface from a geopressured system will be a mixture of steam, noncondensable gases (mostly methane), and 1iquid. During flow testing, the geothermal fluid will pass through a three-phase separator that will separate the fluid into noncondensable gas and methane; liquid; and condensate. Each effluent may then be disposed of in an appropriate manner. The gas phase may be burned and released to the atmosphere. Flow of fluid to the surface will be reinjected, stored in evaporation ponds, or released to the ocean or other surface waters. The chemical composition of geothermal fluid varies from reservoir to reservoir. Chemical compositions of fluids from various geothermal systems are discussed in Sect. 3.2.1.3. During production testing, extensive monitoring and analytical work will be done to determine the quantity of all potential toxic concentraticrs present 
in geothermal fluids, to evaluate their possible threat, and to determine what control measures are required to maintain environmental quality.

\subsubsection{We11 abandonment}

If a well is not proven productive or if a producing well becomes unproductive, the well will be abandoned. Requirements for abandoning and plugging the well vary with factors such as the type of hole drilled, depth, and the formations encountered, All abandoned wells will be plugged in an appropriate manner according to State, Federal, and local regulations. In general, abandonment procedures are designed to prevent any fluid movement within the well bore. All structures will be removed from the area, and the site will be revegetated.

\subsubsection{Field development}

Field development is the drilling of additional wells to develop a geothermal field after successful production testing. This may continue over a pertod of several years. Environmental disturbances will be simIlar to those described previously but will be cumulative as new wells are drilled and completed. The additive nature of the effluents and effecte may necessitate more stringent controls than those Imposed during test drilling. Additional roads will be required, and all access roads will be improved for permanent service. Personnel requirements will Increase, and additlonal services and factlities will be necessary. The extent of surface disturbance w111 increase significantly. One important consideration is that several wells may be drilled from one drill site using new drilling techniques. 
Total environmental effluents will be an accumulation of pollutants from each well site and will depend on the timing of field development. Effects and effluents during drilling operations have been considered in Sect.,3.1.2. As wells are completed, they are shut in until they can be connected to the geothermal system. During the shut in period, the wells will be permitted to vent a sufficient amount of geothermal fluid to the atmosphere to prevent plugging of the well. Small amounts of steam, noncondensable gases, and water from venting will be controlled at the wellhead. The cumulative effect of many wells ready for production could be significant.

Well spacing is an important consideration in field development. Wells spaced closely to the power plant and to each other will result in minimal energy loss in transit and minimal disturbance of the surface. Wells with large separations reduce interference and depletion effects. Models are required to optimize well spacing and to prescribe a development. program requiring a minimum of new wells during the project $11 \mathrm{fe}$, while developing the field to the fullest. Depletion characteristics and desired plant lifetime for the generating plant will determine the rate of production that can be maintained from a given surface area of land. Conceptual designs of geopressured fields use wells spaced $0.8 \mathrm{~km}$ $(0.5 \mathrm{mile})$ apart.

As wells are completed and shut in, the surrounding area will be cleared of all equipment and revegetated. 


\subsection{RESOURCE UTILIZATION}

Resource utilization is defined as the steps leading to and including the use of the geopressured resource. The ERDA geopressure subprogram will include testing of components, subsystems, and processes in field test facilities; testing of integrated energy conversion or utilization systems in pilot plants; and demonstration of economic feasibility with demonstration projects. Each test or demonstration project will have a site-specific environmental assessment prepared, and, in many cases, environmental research and monitoring will precede the project. Potential effects of commercial applications are subdivided into electrical and nonelectrical utilization.

\subsubsection{Electrical production}

Energy in geopressured reservoirs is present as natural gas in solution, as thermal energy, and as hydraulic energy. The estimated heat from known geopressured resources recoverable with present or near-term technology is $2.52 \times 10^{19} \mathrm{cal}$ (100 quads) for electrical utilization and $1.26 \times 10^{20} \mathrm{cal}$ (500 quads) for methane production. 3 Temperatures of geopres sured resources range from $90^{\circ} \mathrm{C}\left(200^{\circ} \mathrm{F}\right)$ to over $190^{\circ} \mathrm{C}\left(375^{\circ} \mathrm{F}\right)$. Salinities for geopressured fluids may vary from a few thousand parts per milion to over $100,000 \mathrm{ppm}$. Schmidt speculates that geopressured zones will have a lower salinity than water from adjacent normally pressured zones. 4 Geopressured reservolrs with high salinities will cause scaling and corrosion problems in the plping system and heat exchangers. Salinity of the geothermal fluid will also be a factor in selecting the geothermal fluid disposal method. 
Without geopressure energy, a temperature of at least $150^{\circ} \mathrm{C}\left(302^{\circ} \mathrm{F}\right)$ is generally required to produce economical electric power from a binary system, and a temperature of at least $190^{\circ} \mathrm{C}\left(375^{\circ} \mathrm{F}\right)$ is necessary to produce economical electrical power from direct flashing. 2

Economic analyses indicate that electricity generation using geopressured geothermal resources is economically and energetically attractive if fluid temperatures approach $160^{\circ} \mathrm{C}\left(325^{\circ} \mathrm{F}\right)$ at the wellhead, if production rates approach $6,360 \mathrm{~m}^{3} /$ day $(40,000 \mathrm{bbl} / \mathrm{day})$ per well, and if the methane content approaches $7 \mathrm{~m}^{3} / \mathrm{kl}$ at $\operatorname{STP}\left(40 \mathrm{ft}^{3} / \mathrm{bb}\right) .^{2}$ Power cycle selection, plant design, and disposal of geothermal fluid also play a role in the economics of electric power generation from geopressured resources.

\subsubsection{Power cycle description}

The net energy produced from a geopressured reservoir includes energy derived from gas recovery, kinetic energy, and thermal energy . Geopressured reservoirs are thought to be saturated with methane gas which would yield from 2.6 to $7.9 \mathrm{~m}^{3}$ at STP of methane per kiloliter of geothermal fluid (15 to $45 \mathrm{ft}^{3} / \mathrm{bb} 1$ ), depending on reservoir temperature and pressure. As wells are produced and pressures drop, some gas will be released from solution. 5 The gas will be recovered from the water by a gas separator. Kinetic energy will be converted to electrical energy by a hydraulic turbine. The hydraulic turbine may require up to three stages and must be built of corrosion-resistant materlal. 
After gas separation and kinetic energy recovery, the thermal energy will be extracted from the fluld as in hydrothermal systems. Three power cycles are being considered for converting thermal energy to electricity: direct flash, binary, and total flow. In the direct-flash cycle, the vapor fraction of the geothermal fluid is separated from the liquid fraction. After particulate removal, the vapor is expanded through a lowtemperature turbine, and electricity is generated. The flashing method Is best sulted to high-temperature and high-salinity resources having a high vapor quality.

In the binary cycle, the geothermal fluid is used to vaporize a secondary working fluid. The working fluid is expanded through a turbine, and electricity is generated. The binary cycle is particularly useful for low-temperature resources where direct flashing would not be economical.

In the total-flow cycle, the two-phase (11quid and vapor) geothermal fluid is used to drive specially designed turbines to generate electricity. The total-flow concept is applicable to any geothermal fluid, but it will be particularly suitable for direct utilization of high-salinity geothermal fluids.

Schematic representations of the three cycles with recovery of gas and hydraulic power are presented in Fig. 3.2 . 


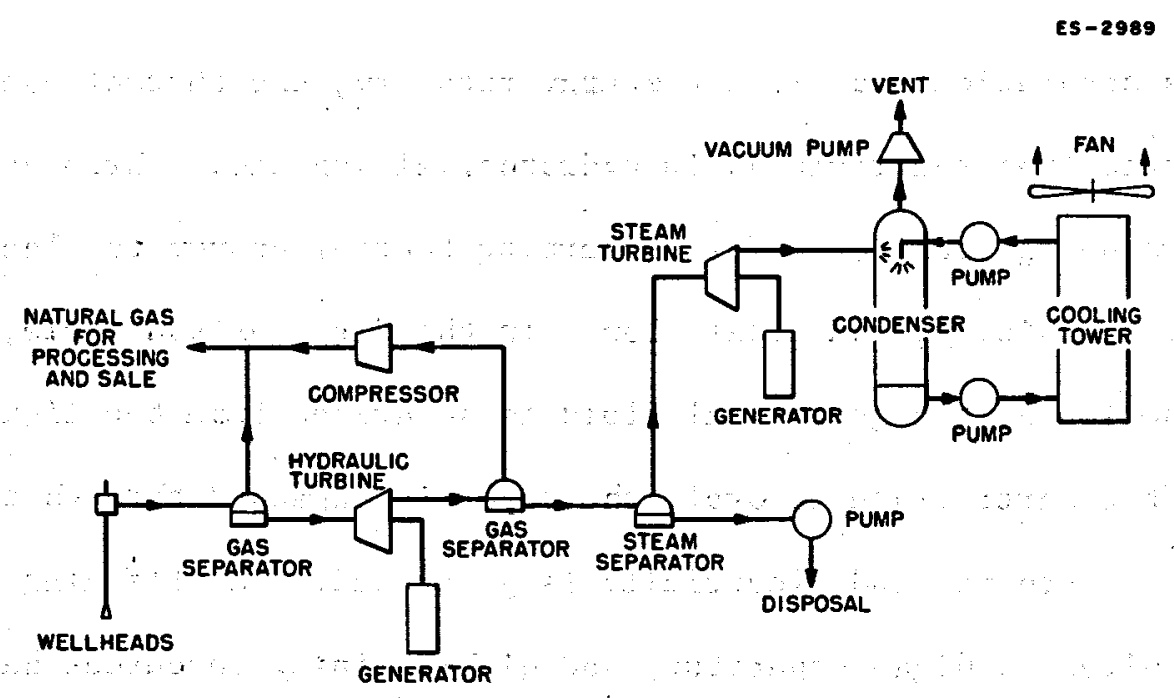

FLASHED - STEAM POWER PLANT

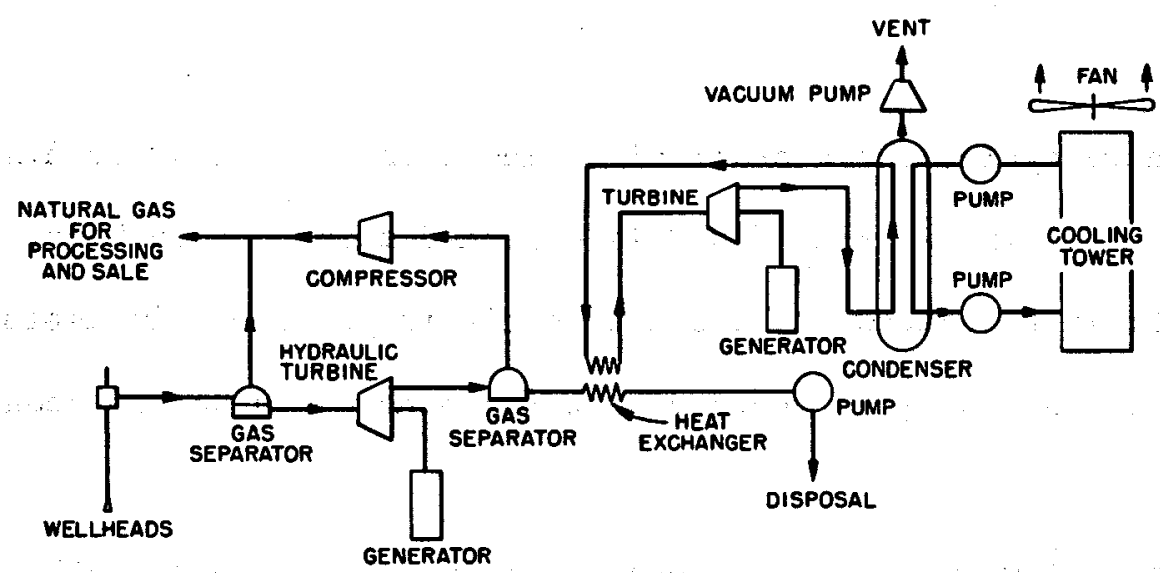

BINARY CYCLE POWER PLANT

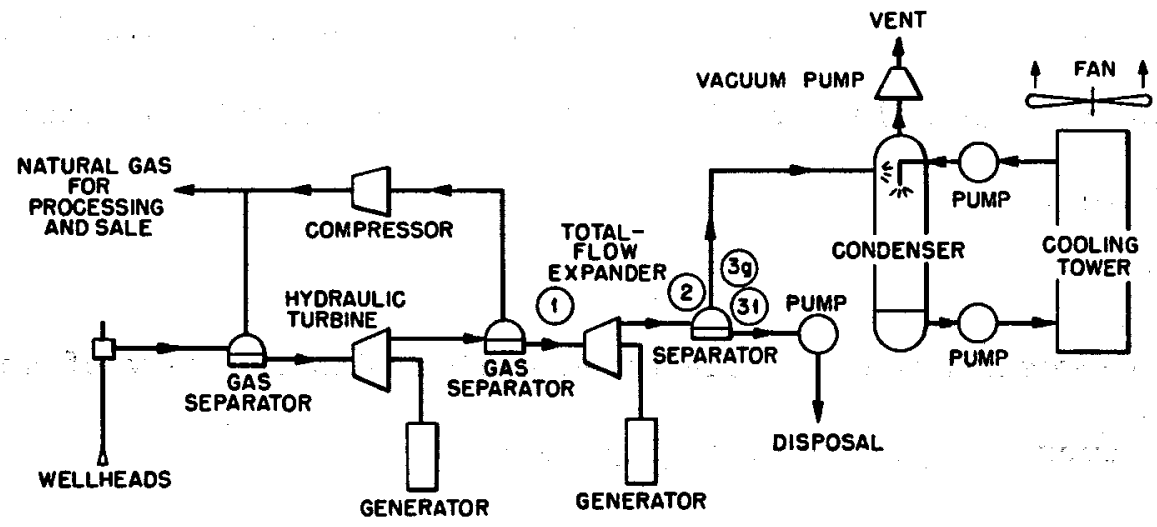

TOTAL FLOW POWER PLANT

Fig. 3.2. Methods for recovery of energy from geopressured systems. Source: P. A. House, P. M. Johnson, and D. F. Towse, Potential Power Generation and Gas Production from Gulf Coast Geopressured Reservoir, UCRL-51813, Lawrence Livermore Laboratory, Calif., May 1975. 


\section{Direct flashing}

To accomplish separation of the geothermal fluid into a vapor phase and a liquid phase, the flash units are operated at pressure below the vapor pressure in the geothermal fluid. This causes the vapor to be withdrawn from the geothermal fluids in quantities that are dependent on the pressure difference between the flash unit and geothermal fluid and the heat content of the fluid. Direct flashing may Involve single-stage or mult1stage flashing. In multistage flashing, the liquid fraction of the geothermal fluid $\mathrm{Is}^{\text {filed }}$ to flash untts operating at succedingly lower pressures. The steam flashed from each stage is fed to the turbine at the point where its pressure matches that of the expanding steam from preceding stages. Mult is tage flashing increases the amount of energy utilized and reduces the well flow rate and cooling requirements. The number of stages designed In a plant depends on an economic-analysis balancing of increased capital costs with reduced well and cooling costs.

Particulates and nóncondensable gases w111 be removed from the vapor before it is fed to the turbine. Particulates are removed with scrubbing devices. Noncondensable gases may be removed by an Initlal flash stage. before being fed to the turbine or by ejection from condensers after being fed to the turbine. Energy losses resulting from an initial flash for removal of noncondensable gases must be balanced againstienergy losses due to Inefficient turbine operation resulting from the presence of noncondensable gases. 
Binary cycle

In the binary cycle, the geothermal flutd vaporizes the working fluid in heat exchangers, and the working fluid is expanded through turbines. The proper cholce of a working fluid is vital to the design of an efficlent binary cycle. Generally, a supercritical Rankine cycle is preferred, and, therefore, the critical temperature of the working fluid must be less than the temperature of the geothermal fluid. In addition to critical temperature, the relative size of the turbine, the operating pressure of the cycle, and the condensing temperature are important in selection of a working fluid. The secondary fluid is usually organic. More heat is extracted from the geothermal fluid by the binary cycle using the proper working fluid than by the direct flash cycle, which loses the latent heat of the flashed steam. Resource utilization efficiency is greater for the binary cycle than for the direct flash cycle.

Noncondensable gases do not present serious problems in a binary cycle arrangement. Hypersaline brines may cause significant corrosion, erosion, and scaling in heat exchangers. These problems may be solved by a hybrid cycle in which direct flashing is used to provide steam for vaporizing the working fluid in heat exchangers. The hybrid cycle is more efficient than flashing alone because the latent heat of the steam is transferred to the working fluid.: Scrubbing of particulates from the steam may be required. 
The binary cycle is in the process of being scaled up but is still considered experimental. A $340-\mathrm{kW}$ binary cycle plant utilizing $81.5^{\circ} \mathrm{C}$ geothermal water and Freon as the working fluld has been operated in Paratunka, USSR. Other Freon plants have operated in Japan. In the United States, binary cycle development using isobutane as the working fluid is progressing in Niland, California, and Raft River, Idaho, in relation to hydrothermal resource development. The Niland geothermal facility is a high-temperature $\left(250\right.$ to $\left.300^{\circ} \mathrm{C}\right)$ high-salinity brine, while that at the Raft River site is moderate-temperature $\left(150^{\circ} \mathrm{C}\right)$ and low-salinity.

\section{Total flow}

In the total flow-concept, power is produced by the expansion of the entire well output of 1ow-quallty (two-phase) steam to the condenser pressure. Expansion can be accomplished by a specialized-impulse turbine or positive-displacement expander. In princlple, the total-flow concept is thermodynamically more efficient than either the flashing or binary cycle concepts and offers a potential for high efficiency at low capital costs.

Major development work is belng done at Lawrence Livermore Laboratory where several total-flow designs have been tested and evaluated. At the present time, a $50-\mathrm{kW}$ axial-flow pure-impulse turbine 1s being constructed. 


\subsubsection{Plant construction}

A geothermal power facility will consist of a surface network of piping, a power plant, and high-voltage power transmission lines. The land in the vicinity of the facility will be changed by the construction of roads, wells, powerlines, power plants, and pipeline facilities. Existing use of the land may be temporarily or permanently changed, and the immediate vicinity of geothermal activity, will restrict the public use of the land. The power plant and well field will require a minimum area of $4.4 \mathrm{~km}^{2}$ $\left(2.73 \mathrm{~m}^{2}\right)$. Lands adjacent to the developed site and made accessible by geothermal development could support multiple uses such as hunting and other recreational activities, grazing, and agriculture. Previously inaccessible unspoiled or wilderness areas may become more accessible.

The power plant will be located on about 4 ha (10 acres) of land adjacent to the geopressured reservoir and will contain housing for power cycle equipment such as heat exchangers, turbines, generators, and condensers; cooling towers; and varlous support facilities such as office space, storage and maintenance, bulldings, parking, and flre water tanks. Geopressure power plants of 25 MWe are being considered for design and are a reasonable size based on existing resource assessments. ${ }^{2}$

The pipeline network is 11kely to be above ground in order to economIcally provide the necessary expansion loops and U-shaped expansion joints in the system for controlling thermal expansion and contraction of the lines during operation. In addition, surface piping allows rapid 
detection of leaks or breaks to ensure minimal spillage of geothermal. brine. Plpelines will be lnsulated to conserve heat, and the elevation above ground will be approximately a meter (several feet), with easements on each side of the pipe. Insulating materlals containing asbestos or fiberglass w111 be used. In pipe design, the effect of surface area and pipe diameter on heat and pressure loss w111 be considered to provide maximum flows at minimum cost and heat loss. PIping will generally be $0.91 \mathrm{~m}$ (36 1n.) in diameter and must be designed to withstand the high pressures expected.2 A buffer zone of 0.6 to $3 \mathrm{~m}$ ( 2 to $10 \mathrm{ft}$ ) may be cleared on each side of the pipeline.

Transmission line construction will involve clearing of rights-of-way, construction of access roads, and erection of towers and lines. Lines from a 25-MWe power plant may be $138 \mathrm{kV}$ and w1ll be hung from wood poles or towers of square-base steel-1attice design. The wood poles will stand about $23 \mathrm{~m}(75 \mathrm{ft}) \mathrm{high}$, have a $0.65-\mathrm{m}^{2}\left(7-\mathrm{ft}^{2}\right)$ base, and allow a $305-\mathrm{m}$ (1000-ft) ruling span. Lattice towers stand from 34 to $43 \mathrm{~m}$ (110 to $140 \mathrm{ft}) \mathrm{high}$, have an average basal area of about $93 \mathrm{~m}^{2}\left(1,000 \mathrm{ft}^{2}\right)$ and, in general, allow about $366-m(1,200-f t)$ ruling span. Varlations in local topography may necessitate occasional reductions in span length, which would require additional towers. Tower-structure design and tower coatings minimize the visual and aesthetic Impacts assoclated with transmission lines. The transmission line right-of-way will be about $46 \mathrm{~m}$ (150 ft) wide. For each $1.6 \mathrm{~km}$ ( $1 \mathrm{mlle}$ ) of $1 \mathrm{lne}$, about $9.6 \mathrm{ha}$ ( 24 acres) of land will be affected. The cleared area beneath the transmission IInes may be used after construction for grazing and other activities. 
Access roads are necessary to provide transportation for materials, equipment, and workmen during construction. After construction, access roads are necessary to allow maintenance of the transmission line system.

Construction requirements will be simflar to those for any industrial or electric construction project. Storage areas for equipment and materials, temporary construction offices and shelters, sources for potable water and electrical power, construction waste disposal areas, and sanitary facilities will be necessary. Construction operations will include construction of access roads; clearing and grading plant, pipeline, and transmission line areas; handling of materials, equipment, and supplies; and disposal of construction wastes. Movement of earth and soll may cause dust particulate problems as well as expose new soll to surface runoff. These effects will be temporary and may be minimized by proper construction techniques and measures such as bank sloping, revegetation, road surfacing, soil stabilization, and adequate erosion and drainage control.

Effluents during construction w1ll not be unique to the geothermal power plant but will be similar to all construction projects. Minor air pollution results from the operation of gasoline powered engines and particulates from surface disturbances. Noise due to operation of equipment and other construction activities may be significant at times. Solid wastes from grading and construction will be disposed of and stabilized in an appropriate manner. Effluents to local streams will include some surface runoff and accidental spills of lubricants, gasoline, and other substances. 
Sanitary facilities will be portable, and wastes will be disposed of in an acceptable manner.

Construction will result in changes in land utilization. Land use will be primarily Industrial development, with multiple land uses possible after construction. Although the facility will be designed to blend into the natural setting by landscaping, vegetation, and color selections, some visual and aesthetic change is inevitable. The visual and aesthetic effects w111 depend on the s1ze and extent of the plant, the topography of the area, the vegetative cover, the techniques used to minimfze impacts, and the proximity to population centers.

\subsubsection{Plant operations}

A geothermal power plant must take in and exhaust more heat than an equivalent fossil-fuel plant because of its lower thermal efficiency. Economics of scale are not presently possible in plant operation because the unit size is limited by reservolr characterlstics and the economic distance for fluid transport. All activities related to electricity generation at a geothermal power plant will be localized to the geothermal resource area around the plant. No offsite support operations such as mining and fuel processing are required. Offsite transmission Iines are typical of any electrical power plant. Power plant operation activities include operation and maintenance of the piping network and power plants as well as drilling, redrilling, and reworking geothermal we11s to maintain production capacity. 
During operation, overall activity will be reduced from that during construction and field development. Many areas previously cleared and exposed to weathering will be revegetated. Wells will continue to be drilled or redrilled as needed to replace or maintain existing wells. Approximately 10 to 12 wells will be required for each 25-MWe plant. ${ }^{2}$ Drilling will involve the same operation described for test drilling in Sect. 3.1.2.

Fluids withdrawn from wells will be transported to the power plant through a surface piping network. The piping and all equipment in the network must be capable of withstanding the high pressures assoclated with geopressured reservoirs. Regular maintenance and inspection of the surface piping will allow early detection and repair of leaks and minimize the loss of geothermal fluid but will require access to pipelines. Piping of high-temperature water under high pressure could be hazardous because rupture of a single line could result in excessive damage.

The geothermal fluld piped to the power plant will be used in one of the power cycles described in Sect. 3.2.1.1. Operational differences in these cycles will be considered. Full-scale production will also involve operation and maintenance of a cooling system and waste control and disposal systems.

Personnel, water, and sanitary facilities are required for plant production support. Personnel required during plant operation will depend on the instrumentation and controls designed in the plant. Water will be 
required during plant production for various purposes including potable water uses, fire protection, to initially fill the cooling water system, and for makeup water. The daily potable water requirement w111 be less than 950 liters $(250 \mathrm{gal})$. Up to 600,000 gallons of water storage may be required for fire protection. 2 The required fire protection will depend on the power cycle design. Water may be supplied by drilling a freshwater we11, by diverting surface waters to the plant, or by importing bottled water. offices and sanitary facilities w11l be provided for onsite operations personnel.

\section{Effluents and effects of operation}

Most aspects of operating a geothermal power plant will be similar regardless of power cycle deslgn. Potential effluents include geothermal fluid, noncondensable gas, noise, and cooling system discharges.

Geothermal fluid. The chemtcal composition of geothermal fluids varies from reservolr to reservoir. Chemical composition of fluid from a geopressured Manchester field well in Louislana compared with a normally pressured well and an idealized geopressured fluid is presented in Table 3.1. The solutes in geothermal waters can be divided into soluble elements and elements with concentrations controlled by mineral equilibria. 6 Soluble elements include chloride, bromide, Lodide, boron, cesium, 11thium, and ammonia. Concentrations of most other elements will be controlled by temperature- and pressure-dependent chemical equilibria. 
Table 3.1. Geopressured Manchester Field compared with normal pressured Hackberry Field

\begin{tabular}{|c|c|c|c|}
\hline ' & Calcasieu Parish & Acadia Parish & Idealized Model \\
\hline Field & Manchester & Hackberry & \\
\hline Well Name & No. 1 W. H. McBurrey & No. 51 Gulfland & \\
\hline Depth & $12,670-12,677$ & 11,500 & \\
\hline \multicolumn{4}{|c|}{$\begin{array}{l}\text { Chemical Composition } \\
\text { (ppm) }\end{array}$} \\
\hline $\mathrm{Na}$ & 6,580 & 49,100 & 3,500 \\
\hline $\mathrm{Ca}$ & 138 & 5,850 & \\
\hline $\mathbf{M g}$ & 18 & 903 & 25 \\
\hline $\mathrm{K}$ & 86 & 309 & 50 \\
\hline Cl & 9,950 & 92,100 & 5,000 \\
\hline $\mathrm{HCO}_{3}$ & 1,330 & 286 & 1,000 \\
\hline \multicolumn{3}{|l|}{$\mathrm{CO}_{3}$} & 76 \\
\hline $\mathrm{Li}$ & 3.1 & 4.5 & 7 \\
\hline $\mathbf{R b}$ & 0 & 0.6 & 0.7 \\
\hline Cs & & 0 & \\
\hline $\mathrm{Sr}$ & 5.3 & 569 & \\
\hline $\mathrm{Br}$ & 33 & 183 & \\
\hline 1 & 27 & 5.3 & 15 \\
\hline $\mathrm{Ba}$ & 0 & 23 & \\
\hline $\mathrm{SiO}_{2}$ & & & 500 \\
\hline TDS & 18,300 & 149,000 & $\sim 10,000$ \\
\hline
\end{tabular}

Source: G. W. Schmidt, "Interstitial Water Composition and Geochemistry of Deep Gulf Coast Shales and Sandstones," Am. Assoc. Pet. Geol. Bull. 57(2): 321-337 (1973).

G. K. Underhill et al., Proceedings of Second Geopressured Geothermal Energy Conference, vol. IV: Surface Techriology and Resource Utilization, Center for Energy Studies, University of Texas, Austin, February 23-25, 1976. 
Higher-temperature waters, the refore, contain higher concentrations of dissolved solids. A single geopressured well may produce from 3,180 to $6,360 \mathrm{~m}^{3} /$ day $(20,000$ to $40,000 \mathrm{bb} 1 /$ day $)$ of fluld with 2.6 to $7.9 \mathrm{~m}^{3} / \mathrm{kl}$ at STP (15 to $45 \mathrm{ft}^{3} / \mathrm{bb1}$ ) of methane produced. About 60,000 to $76,000 \mathrm{~m}^{3} / \mathrm{day}$ (16 to $20 \mathrm{Mgd}$ ) of fluld must be disposed for a 25 -MWe plant.

Geothermal fluids may be disposed of by discharge to cooling ponds, discharge to Irrigation ditches, discharge to the ocean or other saline waters, reinfection, infiltration through sand and gravel pits, or recycling. Surface discharges of geothermal fluid will be used only if compatible with surface-water flows and in compliance with recommended effluent limitations for chemical, temperature, and gas emissions such as hydrogen sulfide, carbon dioxide, and oxygen. Where surface discharge Is not acceptable, infection of the geothermal fluid into normallypressured sand formations 1.5 to $2.1 \mathrm{~km}(5,000$ to $7,000 \mathrm{ft})$ deep appears to be a practical means of disposal. This may be costly due to equipment and power requirements. Pretreatment of the fluid may be required for removal of entrained particulate matter, to control $\mathrm{pH}$, or to mitigate transient conditions. Where the sillcate content of the fluid is excessive, the silicate may be precipitated before injection to prevent plugging of Injection wells. Disposal wells may be drilled specifically for injection, or depleted oil wells in subsurface reservolrs below the : freshwater table might be used for Injection. 
Noncondensable gas: Geothermal steam generally contalns small quantities of noncondensable gases including carbon dioxide, hydrogen sulfide; hydrogen, methane, nitrogen, and ammonia. No analysis of the quantities of noncondensable gases in geopressured reservolrs has been reported. The total gas content and the relative concentrations of the constituents depend on the geochemistry of the underground reservoir. Geopressured reservoirs are expected to be saturated with methane. The methane and other gases will be separated from the geothermal fluld at the power plant and will be processed for sale. Small quantitles of noncondensable gases released during flashing may not be profitable for recovery, and the gases may be released through stacks if concentrations are acceptable. Means for removing and collecting noxious gases may be developed as required by Individual geothermal systems. Gases may also be compressed and pumped down Injection wells. Studies on methods for controlling hydrogen sulfide emlssions from geothermal power plants are being supported by ERDA.

No1se. Notse levels during plant operation may be significant and will result from steam and gas separation, pressure reduction, venting, cooling towers, turbines, and the general power plant area.

Cooling system. Condenser cooling will be accomplished with wet cooling towers, dry cooling towers, cooling ponds, or once-through cooling. The cooling system selected will depend on the design cycle, water availability, land area, recelving water standards, and climate. 
Mechanical- or natura1-draft wet cooling towers will probably be used where the system design permits steam condensate from the power plant to be used as cooling tower feed water. No nongeothermal source of freshwater is required in such a design. Where geothermal condensate is not avallable for cooling water (as In a binary cycle), a source of freshwater Is necessary for condenser operation. This could require up to 400 ha-m $\left(3,400\right.$ acre-ft) of cooling tower makeup water annually for a 25-MWe plant. ${ }^{2}$ Effluents from the cooling tower result from evaporation, drift, and blowdown. Drift and blowdown contain trace elements carrled over from the geothermal steam to the condensate when condensate is used as cooling tower feed. Chemicals to control scaling, corrosion, algae, and fungl In the system may not be required in condensate cooling. Drift eliminators minimize the loss of water droplets from towers, but fog and mist are st1il associated with areas adjacent to cooling towers. Blowdown will be released to the environment or reinjected with the waste geothermal fluid where appropriate to specific applications Sollds from cooling tower operation will be disposed of in approved solid disposal areas:

Dry cooling towers or hybrid wet/dry cooling towers may be used where freshwater is required in a water-deficient area. In a dry tower, air Is drawn over banks of tubes through which process cooling water flows. All heat is dissipated to the alx, and there is no evaporative cooling. Heat transfer is not as efficient as wet cooling towers, and capital and operating costs lare usually higher. Cool, dry climates would be the most advantageous for Installation of dry cooling towers. Dry towers do not consume water and produce no effluents. 
Cooling ponds may be used where a large land area is avallable. Some makeup water is required to replace evaporation, and ground seepage problems are posstble with cooling ponds.

Once-through cooling in which freshwater is passed over heat exchangers one time before discharge may be considered for areas with an abundant water supply to the extent permitted by law.

Corrosion and scaling. Plant operation may result in corrosion, eroston, scaling, and plugging of drilling equipment, borehole casing, and surface plumbing and equipment when hot mineral-laden geothermal fluids are used. The corrosion potential will depend on the nature and concentration of dissolved salts and gases, the temperature, the $\mathrm{pH}$, and the amount of oxygen in the geothermal fluid. Erosion may result from entrained particulate matter in the geothermal fluid. Scale is formed by precipitation of silicates, carbonates, and sulfates from the geothermal fluid. The ERDA is currently supporting research in this area. Control of the problem may be accomplished by using expensive corrosion-resistant materials for plant construction, by reworking wells, and by cleaning or replacing surface piping. No effluents result in addition to those previously mentioned.

Water. During operation of the power plant, withdrawal of, fluids may. cause the groundwater and surface hydrologic regime to change and may Influence the avallability of water in the area. Withdrawal and disposal of geothermal fluids could result in contamination of freshwater aquifers 
If one aquifer horizon were not kept 1solated from another by properly cementing the casings of production and injection wells.

at

Energy recovery

Dissolved methane, kinetic energy, and thermal energy are the three forms of usable energy contained in geopressured reservolrs. Natural gas is belleved to be near saturation in the pressurized hot brine from a geopressured reservoir and is recovered as pressure is reduced in the geothermal fluid. The natural gas will be collected at several stages during power production and will not be of pipeline quality. A fuel plant may be constructed as part of the geothermal power plant to process the natural gas to pipeline quality. Processing of the recovered natural gas will involve cooling, pressure adjustment, and dehydration.

Kinetic energy will be recovered from the geopressured reservolr by converting the high wellhead pressures to electric power by use of a hydraulic turbine. The hot fluid will be a two-phase system at a high temperature, which may cause corrosion and erosion problems.

After pressure reduction and gas separation, the fluid from a geopressured reservolr is similar to that from a hydrothermal reservolr, and one of the three cycles described in Sect. 3.2.1.1 may be used to recover thermal energy .

Direct flash cycle. In the direct flash cycle, hot brine is flashed in a steam separator or flash tank, and the vapor fraction is used to operate 
a turbine while the liquid fraction is discharged to settling ponds or relnjection wells through silencers to reduce noise levels. Nolse levels will be high for workers. The fluid will most likely be flashed at the power plant after pressure reduction and recovery of natural gas.

The percentage of geothermal steam mass flow after flashing will depend on the temperature and pressure of the geothermal fluid before and after flashing. Generally, the steam mass flow will be in the range of $10-30 \%$ of the total mass flow. The remaining liquid fraction will retain slightly higher concentrations of trace elements and dissolved solids than the fluid before flashing. The geothermal steam is expanded as it passes through the turbine to the condensers. The low temperature and pressure of geothermal steam requires large turbines relative to the generating capacity. The most economical turbine size at present appears to be 50 MWe or less, but more than one turbine may be installed in a plant.

The steam condenser will operate at a vacuum providing low turbine back pressure to maximize energy extraction. Noncondensable gases will be removed with gas ejectors and released to the environment through appropriate gas cleanup systems to maintain the vacuum. Condensers will be direct-contact or surface heat exchangers, depending upon the method of control of noncondensable gas. Direct-contact condensers are cheaper, require less cooling water, and present fewer corrosion problems than surface heat exchangers. Water-soluble gas components tend to dissolve in and discharge with the cooling water in direct-contact condensers. 
Surface condensers allow easler handling and control of noncondensable gas by keeping the flows separated, thereby providing a more concentrated stream of noncondensables for removal.

In the direct flash cycle, wet cooling towers are usually used to provide cooling for the condensers. Condensate is used for feed to the cooling water, and the need for freshwater sources of condenser cooling water is reduced or eliminated.

Most of the steam condensate from the system will be lost to evaporation and drift through the cooling tower with the remainder discharged as cooling tower blowdown with the unflashed brine.

Binary cycle. In the binary system, hot fluid is passed through a heat exchanger to transfer the thermal energy to a noncorrosive working fluid such as fsobutane or fluorinated hydrocarbons. The vaporized working fiuld is used in a turbine for producing electrical energy. The turbines required are smaller than those required by an equivalent direct flash system because organic vapors are much denser than steam. In the binary system, both the geothermal brine and the working fluid are contained in closed cycles away from exposure to the atmosphere, and noncondensable gases are not released to the atmosphere. The geothermal fiuld may be reinjected to avold thermal and chemical pollution of surface waters with a typical loss of only about $2 \%$ of the total mass flow.

While alr quality is improved in this system, nongeothermal water must be used for condenser cooling because the temperature of the geothermal 
fluid is too high to condense the binary flutd. As much as $400 \mathrm{ha}-\mathrm{m}$ $(3,400-4,800$ acre-ft) of cooling tower makeup water for a 25-MWe plant will be required in a binary cycle operation ${ }^{3}$ when wet cooling towers are used. Dry cooling towers and cooling ponds may be used, depending on specific conditions.

Total-flow cycle. Turbines developed for the total flow cycle are likely to be noisy and require massive walls to withstand the stored energy. At the turbine outlet, the geothermal fluid will pass through a condenser for cooling. A cooling tower or spray pond will usually be required. The quantity of makeup water required will depend on evaporative cooling losses vs the cooling tower feed from condensed vapor.

\subsubsection{Nonelectrical applications}

The potential utilization of geopressured geothermal energy for nonelectric applications is limited by the resource's distribution and the economics of resource recovery. Geopressured zones situated in rural areas would require the establishment of new industries to utilize the geothermal fluld, whereas in more industrial areas, new industry or expansion or modification of existing industries would be required. Nonelectric applications may be sultable for the use of natural geothermal fluids or may require upgrading of the geothermal fluid.

Nonelectric application of geothermal resources are economically attractive in the low- to moderate-temperature range from $50^{\circ} \mathrm{C}$ to about $150^{\circ} \mathrm{C}$. Below $50^{\circ} \mathrm{C}$, utilization of geothermal water is limited, and above $150^{\circ} \mathrm{C}$, production of electricity becomes more feasible. 


\subsubsection{Applications}

Nonelectric energy derived from geopressured reservolrs will be useful

for applications requiring slgnificant low-grade, low-temperature energy at a relatively high-energy density. Nonelectrical uses of geothermal energy include:

1. residential and comercial uses for space and water heating, space cooling, augmenting water supply, waste treatment, refrigeration and delcing;

2. agricultural and related uses for hydroponics, animal husbandry, and aquaculture;

3. Industrial proces s ues for chemfcal production, pulp treatment, mining, drying, water desalination and distillation, mineral recovery, and was te treatment;

4. balneology and tourism including health spas, hospitals, sanitoriums, and bottled water.

Energy is consumed for many purposes in comercial and residential areas and those uses requiring relatively low-temperature levels, such as space heating, water heating, and drylng, are suitable end uses for geothermal energy. Space or water heating and alr conditioning may be provided by a district heating and cooling system In which themal energy in the form of steam or water is distributed by a network of insulated piping. Space and water heating can be accomplished with heat exchangers, whlle cooling can be provided by an absorption cooling system. The distribution network is capital-intensive and can be a major portion of the total system 
cost. Transportation and distribution costs will depend on market size, fluid temperature, load density, distribution from the geothermal field to the market, and complexity of the system for distribution and disposal.

Warm geothermal waters may be used to establish and maintain optimum temperature conditions for plant and animal cultivation. The primary agricultural application for geopressured geothermal fluids is hydroponics. Hydroponics includes the use of geothermal fluids for greenhouse heating and plant irrigation. The purity of the geothermal fluid is important in direct soll heating applications. By using heat exchangers, heat may be transferred from the geothermal fluid to water, which can be directly used on crops. However, climate along the Gulf Coast is mild, and frost prevention would have low priority. Winter and summer greenhousing to maintain optimal growing conditions is feasible.

Geothermal fluids may also be used in animal husbandry for heating, cleaning, sanitizing, and drying of animal shelters. There is evidence that some animals respond to an optimal thermal environment with increased production, growth rate, and feeding efficiency.

Aquaculture is the practice of cultivating aquatic species under controlled environmental conditions. Geothermal fluids may be used to maintain optimal environmental conditions year-round and promote increased growth and feed efficiency. 
For agricultural operations to be an attractive geothermal utilization market; the supply system must be Inexpensive, the agricultural operation must be intensive, or the agricultural utilization must be secondary. In general, it has been concluded that unless agricultural operations are very Intense and coordinated, agricultural utilization of geopressured fluids Independent of a major base load will be uneconomical because of the very large fuel plant capital costs. ${ }^{2}$ Large scale hydroponics operation with heating, alr circulation, cooling, and product processing may be economical.

Industry requires electrical energy, direct heat, and process heat. Geothermal resources suitable for nonelectric applications can provide process steam and moderate- to low-temperature process heat for such applications as heating, evaporation, drying, distillation, refrigeration, sterilization, washing, and defcing. Heat may be transferred from the geothermal brine to a working fluid or used directly as flashed steam. Industrial complexes could consume as much as 50 me equivalent per plant. Geothermal fluids may also be used to derlve raw materials such as salts and valuable chemicals for industrial use and development.

Energy-intensive industry is concentrated quite heavily in portions of the Gulf Coast, and there may be substantial potential for direct ut1lization of geothermal heat from geopressured reservolrs. Direct use of the thermal energy may be the only economically viable way to utillze the lower-temperature geopressured aquifers. Successful Industrial utilization will depend on the technology avallable for resource 
utilization, the location of the resource with respect to existing and potential markets, and the economics of ut1lization. Industrial ut111zation of geopressured energy requires that the fluids be located within less than 50 miles of the industry and that the fluid disposal capacity be located reasonably close by. Table 3.2 lists the possible industrial applications of geopressured geothermal fluid in the Gulf Coast region.

\subsubsection{Construction and operation}

Development of the nonelectrical geothermal resource will involve resource exploration and assessment, drilling of wells, and field development. Resource exploration and well drilling will be similar to the descriptions in Sect. 3.1. The number of wells required will depend on the nonelectrical application, the well performance, and the system design. Flow rate and performance of a particular well will depend on the fluid volume in the aquifer, the permeability of the formation, the physical restrictions of the drilled well and piping, and the type of completion equipment. Energy for nonelectrical geothermal applications may also be provided by the effluent from geopressured power plants, if the byproduct waste water has sufficient quantities of heat.

Nonelectrical geothermal energy systems could include gas separators, a hydraulic turbine, a main pipeline from the well or wells to the distribution system, a distribution system, a steam separation system, heat exchangers, a collection system, and a disposal system. The components of each nonelectrical system will depend on the nonelectrical application 
Table 3.2. Potential industrial applications of geopressured resources on the gulf coast

1. Climate control

District cooling and heating with cooling accomplished

by absorptive or compressive processes

2. Industrial applications

Sugar cane refining

Paper manufacturing

Sulfur recovery by the frasch process

Petroleum and natural gas pipeline pumping

Processes requiring low-level process heat

Cold storage and frozen food preparation

Water desalination

Air reduction and liquefaction process plants

Lumber and concrete block curing kilns

3. Secondary applications

Secondary recovery of petroleum

Makeup for coal slurry pipeline

Makeup for power plant cooling lakes

Source: G. K. Underhill et al., Proceedings of Second Geopressured Geothermal Energy Conference, Vol. IV:

Surface Technology and Resource Utilization, Center for Energy Studies, University of Texas, Austin, Feb. 23-25,

1976. 
and the system design. In general, construction of a nonelectrical system involves the assembly of piping in varying sizes and installation of valves, regulators, meters, expansion foints, and controls necessary for reliable operation of the pipe network. Heat expansion will be controlled with bellows, slip joints, or U- or Z-shaped joints. The system must be thermally insulated to prevent excessive heat 1 oss and temperature drop. Some insulation materials may present health hazards and should be handled carefully. Pipes may be installed in many ways - from burlal in concrete trenches to burial of prefabricated pipe within a pipe containing Insulation in the annulus. The system design must include a means for pressure control and gas recovery. Where wellhead pressure is not to be reduced, the entire system must be designed to withstand expected pressures. Wellhead pressure may be maintained in the system to be used for injection of the waste fluid. Alternatively, the system may be designed for initial pressure reduction by a hydraulic turbine or other means before entering the distribution system. The gaseous portion of the geothermal fluid consisting primarily of methane will be released as pressures are reduced. The gases will be recovered with gas separators and processed for discharge to existing natural gas pipeline systems.

The area disturbance and extent of impacts during construction will depend on the ruggedness of the area terrain and the size of the nonelectrical geothermal system. Equipment for clearing, trenching, pipe installation, and backfilling will be required. Operation of equipment will result in minor air pollution and noise. Surface and vegetation disturbance along the pipeline corridor will be unavoldable and could 
cause some erosion and siltation of drainage areas and surface streams: Problems inherent at all construction sites such as fugitive dust, soil disturbances and movement, disposal of construction wastes, materials handling, and impacts on aesthetic quality are 11kely to occur. In some areas, construction of access roads may be required. Where piping must pass through developed areas, considerable disruption and Inconvenience may result for persons occupying surrounding buildings or where traffic interference occurs.

During operation, the flow will pass through gas separators, and the pressure may be reduced by hydraulic turbines or other means if required. The nonelectrical application system design may require flashing of the fluid for direct use of steam, direct use of the geothermal fluid, or use of the geothermal fluld in heat exchange systems.

Environmental problems resulting from nonelectrical applications of geopressured energy will be similar to those described for production of electricity from geothermal energy. Steam or hot water production and utilization involves waste disposal of geothermal fluids, thermal pollution, subsidence, triggering of seismic effects, noise, alr pollution due to noncondensable gases, ecological disruption, and aesthetic effects. These are described in detall in Sect. 3.1 . 


\subsection{ENGINEERING RESEARCH AND DEVELOPMENT}

Advanced driling technology will involve improved drill bits and automated rigs, high-temperature drilling fluids, elastomers, cements, and down-hole sensors and directional drilling in hard fractured rock. Drill bits will be designed for increased penetration rates, reduced bit wear, and reduced trip time to minimize driliing costs and drilling time. ERDA is currently supporting research for developing and testing new drilling equipment. Modern mobile drilling rigs capable of attaining depths up to $4 \mathrm{~km}$ and equipped for rapid changes in drilling procedures as hole conditions change are to be investigated. These developments can reduce the total release of effluents from the reservoir during drilling because of reduced drilling time.

Improvement of drilling fluids, elastomers, and cements for hightemperature use will reduce the risk of blowouts and casing failures previously caused by deterioration of these materials at high temperatures. Directional drilling in hard fractured rock will allow the drilling of more than one hole from the same drill pad. This will decrease the number of disturbed areas for drill-pad construction and reduce the amount of piping required. Nontoxic drilling fluids are also available and may be used to reduce impacts if necessary.

Development of equipment and methods for well stimulation and down-hole pumping to improve the flow from marginal wells could decrease the 
number of wells abandoned and reduce the number of wells eventually drilled in a reservoir.

Equipment and technology need to be improved and developed for utilization of the advanced power cycles. The Energy Research and Development Administration will be supporting research associated with heat refection equipment, fluidized-bed and direct-contact heat exchangers for the binary cycle, total flow systems (consisting of turbines handling both steam and liquid phases), and down-hole pumps. In addition to equipment development, research in brine chemistry, scale control, and materials (2) compatibility will be supported to cope with the severe chemical and thermal environment encountered with geothermal fluids. Equipment and techniques will be evaluated at field test facllities, pilot plants, and demonstration plants. 
REFERENCES FOR SECTION 3,

1. U.S. Geological Survey, Geothermal Resources Operational Orders:

GRO Order 2. Drilling, Completion, and Spacing of Geothermal Wells, USGS, Menlo Park, Calif., January 1976.

2. G. K. Underhill et al., Proceedings of second Geopressured Geothermal Energy Conference, Vol. IV: Surface Technology and Resource Utilization, Center for Energy Studies, University of Texas, Aust1n, February 1976, pp. 23-25.

3. Energy Research and Development Administration, Definition Report: Geothermal Energy Research, Development and Demonstration Program, report ERDA-86, October 1975 .

4. G. W. Schmidt, "Interstitial water composition and geochemistry of deep Gulf Coast Shales and Sandstones,"Am. Assoc. Pet. Geol. Bulz. $57(2): 321-337$ (1973).

5. P. A. House, P. M. Johnson, and D. F. Towse, Potential Power Generation and Gas Production from Gulf Coast Geopressure Reservoirs, report UCRL-51813, Lawrence LIvermore Laboratory, Livermore, Callif., May 1975.

6. A. J. E111s, "Geothermal Systems and Power Department," American Scientists, 63: 510-521 (1975). 


\section{ENVIRONMENTAL EFFECTS}

The physical and blological effects of geopressured geothermal energy development may vary greatly because of the varlety of physlography and yegetation that may be encountered. Habitat types include barrier islands, marshes, and upland areas. Offshore environments have not been included in this assessment.

Much of the data presented in this assessment is preliminary and based on few observations. This is especially true for fluid characteristics and chemistry. Further, most of the data that is available is from Texas with little data avallable for Loulstana reservoirs. Salinity and noncondensable gases contained in the flulds may be greatly underestimated If the analysis is based solely on this preliminary data. Therefore, this analysis is based on potentially less optimistic conditions for most development situations.

The direct biological effects of development on barrier islands are potentially small because of their low blotic productivity, which results from the combination of salt spray and low water avallability. The largest potential direct ecological effect is the forced abandonment of seabird rookeries due to disturbance. Major indirect effects may result from the disturbance of dunes and their stabilizing vegetation. Hurricanes and tropical storms are common in this area (Sect. 4.3.1); the high winds and seas assoctated with these storms can cause considerable movement of Inadequately stabilized dunes and intrusion of seawater, resulting in losses of vegetation and property. 
Salt-, brackish-, and freshwater marshes are common in the geopressured region. These community types will experience the greatest impact from development. Development activities involve elther dredging for canals and ponds or filling for roads and pads. Dredging destroys marshlands directly by the removal and dumping of spoils and Indirectly by changing flow patterns and salinity regimes. Dredging of existing waterways displaces benthic communities and creates turbidity that can damage the respiratory surfaces of flsh and zooplankton, bury or suffocate benthic organisms, and release buried toxic materials. Dredging also produces spoils that must be discarded; disposal at sea results in further effects on benthic organisms. Filling covers marshlands and can cause changes in flow and salinity patterns that result in vegetational changes. Erosion of $\mathrm{f} 111$ and spoil piles can reduce productivity over an additional area. Coastal marshes are highly valued for their ability to assimilate waterborne wastes; absorb the energy of storms; support waterfow1, furbearers, and other wildlife; and supply detritus to the estuaries that serve as nursery grounds for marine fisheries. The use of existing disturbed areas will result in minimal impact of the geopressured geothermal energy development in these marshes.

Upland areas will be disturbed less by development than will wetlands. The prime concern in uplands is the rarity of the biotic communities involved. Because of existing agricultural development, native coastal prairie, normally expected in this region, has become a rare community type. A secondary but important consideration is the productivity of the land involved. Both agricultural and natural biotic productivity are valuable resources. 
Local impacts will vary seasonally In some cases, such as those involving habitat for overwintering birds or breeding grounds in coastal marshes. Such variations will be considered on a site-specific basis when needed to mitigate impacts.

Endangered species and their critical habitats are protected by the Endangered Species Act of 1973. Federally listed threatened and endangered species that are found in the geopressured region are 11sted in Table 2.6. Louisiana and Texas also have official lists of endangered wildlife.

\subsection{RESOURCE DEVELOPMENT}

Development of a potential geopressured resource area generally will create potential impacts of a temporary nature that are less intensive than those of the utilization phase. The magnitude of impacts will be a function of the magnitude of development effort (1.e., the number of test holes, quantity of personnel and equipment, and number of roads).

\subsubsection{Reservoir exploration and assessment}

The physical and biological effects of field exploration vary in degree, depending on local conditions and the operation Involved. Extensive drilling for oil and gas along the Texas-Louisiana coast has already provided a detailed analysis of the area's geologlcal environment. $A_{\text {: }}$ thorough 1iterature search and analysis of previous publications, aerial photography, and drilling logs will reduce the need for extensive 
exploration activities. However, when warranted, additional geological or geophysical surveys will pose a potential environmental impact.

\subsubsection{Physical effects}

Reconnaissance and geophysical operations will pose minimal physical Impacts. Local reconnaissance techniques are predominantly surfaceoriented and vary in their environmental effects. Geological and geochemfcal exploration have negligible impact; data are gathered on foot, and existing trails and roads are used when practicable. If cross-country vehicle use is warranted, temporary surface scars and local increases in erosion may occur.

Initial geophysical exploration also has little impact. These surveys Involve small crews of one to five people, the use of one to three small trucks, and activities that include gravity, magnetic, resistivity, magnetotelluric, radiometric, microseismicity, seismic noise, and ground nolse studies. Because vehicular traffic is generally limited to existing roads, physical impacts are minimal. However, establishment of field camps and use of cross-country vehicles may create temporary surface scars and local increases in erostion.

The later stages of exploration - active selsmic, shallow-temperature, and stratigraphic studies - have a somewhat greater potential for physical impacts. Active selsmic studies and the drilling of shallow-temperature holes require five to seven trucks, up to 15 people per site, the possible clearing of temporary roads, and a surface disturbance of 9 by $9 \mathrm{~m}$ ( 30 by 
$30 \mathrm{ft}$. Where possible, drilling can be minlmized by using abandoned selsmic shot holes for shallow-temperature observation. Stratigraphic holes reaching to a depth of $760 \mathrm{~m}(2500 \mathrm{ft})$ or more require a greater site clearance of 12 by $18 \mathrm{~m}$ ( 40 by $60 \mathrm{ft}$ ), a portable rig, three threeman crews, and intermittent traffic along existing or cleared roads. Reserve ponds will be necessary with most drilling activities ...:

Thus, selsmic, shallow-temperature, and stratigraphic operations have potential short-term impacts due to (1) noise, (2) fumes released from machinery, (3) accidental release of reserve pond contamination to surface or groundwater, (4) accidental contamination of groundwater from drilling, (5) use of local water resources for drilling, (6) increases In water turbidity, (7) siltation of streams, (8) erosion, and (9) changes in topography, aesthetics, and land use. Each of these 1mpacts is controllable to an acceptable level with proper planning and management. $\because a^{2}$

\subsubsection{Biological effects}

Because the Gulf Coast has been intensively explored by the oil and gas industry, surface geologic exploration should be less extensive than it would be in other regions, and most of it can be conducted from existing roads and water courses. Blological effects should be small.

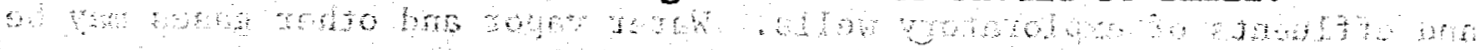

Drilling for active seismic, shallow-temperature, and stratigraphic

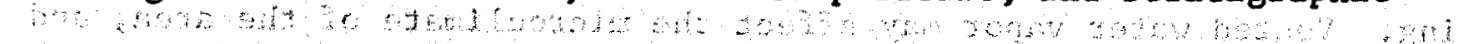
studies may produce significant local effects. Vegetation must be cleared from the drilling pad $\left(80\right.$ to $\left.210 \mathrm{~m}^{2}\right)$ and from any access roads 
that are built.- Drilling in wetlands involves dredging or filling, which results in depletion of marsh and aquatic biota. Because of possible leakage and inundation of mudpits during storms or floods, nontoxic drilling muds will be used where practicable, thus limiting impacts.: Although the duration of these activities is short, the noise, fumes, and general level of human activity will displace waterfowl and other wildife from the immediate area.

\subsubsection{Test driling and protection testing}

Four phases of exploratory well drilling follow field expioration: well-site preparation, drilling operations, well testing, and well abandonment. These activities have potential environmental impacts and require adequate controls and planning such as those contained in the Department of the Interior Regulations 43 CFR 3204.1. The field development that may follow consists of further exploratory well drilling to define the geothermal field. Environmental effects are similar to those of well drilling but are cumulative in nature.

\subsubsection{Physical effects}

Air, water, and land quality may be affected by the excavation, drilling, and effluents of exploratory wells. Water vapor and other gases may be released into the atmosphere during uncontrolled venting and well testing. Vented water vapor may affect the microclimate of the area, and during colder temperatures, fogs or ice may result. Potential noncondensable gases associated with the geopressured fluids Include carbon 
dioxtde, nttrogen, hydrogen, ammonia, hydrogen sulfide, methane, ethane, and other hydrocarbons. These and other gases may be present in suff1clent quantitles to degrade alr quality or create health hazards. Vented methane and hydrogen sulfide will be burned off at some wells, thus releasing sulfur dioxide. In addition, air quality may be affected by exhaust emlssions released from the operation of vehicles, drill rIgs, and accessory equipment.

The potential for affecting water resources is also important. Construction of roads and drill sites may increase siltation and/or turbidty of streams. Along coastal areas, dredging and increased boat traffic may also influence water quality and turbidity. Thermal or chemical contamination of surface or groundwater may result from Improper disposal of fluids, blowouts (Sect.4.3.4), spillage, and leaching of holding ponds and mudpits. Leakage is minimized when sumps are located topographically where they are not affected by runoff and when an Impermeable lining is provided. In certain states, the use of holdIng ponds is permitted only on a temporary basis Contamination of groundwater from well-casing fallure in freshwater aquifers, accidental and improper intercepticr of artesian aquifers, or improper reinfection of hydrothermal fluids are other possibllities. Local water consumption during drilling is moderate and requires an estimated maximum of 12,000 gpd. Shates Physical Impacts of land clearing include potential erosion and soil contamination. Several acres of land may be cleared for temporary roads 
and bulldings. Drill sites generally require 1 to 2 acres and no more than 5 acres. Both roads and drill sites are used throughout the year and are covered with gravel and/or oil, if necessary, to control erosion and fugitive dust. Alterations in topography, increases in erosion, and posstble landslides are of greatest concern in areas of high relief where solls are unstable and cut-and-fill methods are used. Erosion can be lessened when techniques such as mats, water breaks, contour trenches, or vegetation buffer strips are used. Along coastal areas, alterations In topography and increases in erosion may also develop because of dredging and landfill techniques. Further 1mpacts may result from disposal of drilling muds and improper containment of reservoir fluids. In addition, after proper disposal of holding pond precipitates, residual salts will inevitably remain in the soil and may cause soll contamination caused by leaching.

Exploratory drilling w11l also influence aesthetics and land use. The test site will be occupied for one to two months, during which time the drill rig and vapor plumes may be visible, depending on topography, remoteness, and vegetation. Scars from roads and the excavation site will lèssen scentc quality for several months in wet areas to several years in artd areas. Noise from both drilling and venting operations will reach high levels - up to $125 \mathrm{~dB}$ if unchecked (Table 4.1); muffler systems and proper safety measures may be required. Land use may involve competition with agricultural, grazing, historic, or recreational uses. 
1. Table 4.1. Comparison of noise levels between The Geysers (California) hydrothermal resource area and other noise sources

\begin{tabular}{ccc}
\hline Source & $\begin{array}{c}\text { Level } \\
{[\mathrm{dB}(\mathrm{A})]}\end{array}$ & Distance (ft) \\
\hline
\end{tabular}

The Geysers

Drilling operation (air) 126 25

Drilling operation (air) 1500

Muffled testing well

Muffled testing well

55

100

Steam line vent

65

1500

Steam line vent

100

50

90

250

Comparative levels

Jet aircraft takeoff

125

Threshold of pain

120

200

Unmuffled diesel truck

100

Average

Street corner in a large city

75

Residential area at night

40

50

Average

Average

Source: Energy Research and Development Administration, An Assessmenit of the Environmental Impact of Alternative Energy Saurces, ORNL-5024, U.S. Department of Commerce, Springfield, Va., 1974. 
Upon completion of all testing, the well will be abandoned if it is unproductive. All equipment, drilling mud, and effluents will be removed, all holding ponds will be backfilled and leveled, and the well will be plugged, as required, to prevent any fluid movement within the well bore. The area should then be reseeded and returned to a natural vegetation condition.

The impacts of field development are Identical to those of test drilling but are cumulative in nature. Because of this, more stringent control measures than those required during exploratory drflling may be necessary.

\subsubsection{Biological effects}

Preparation for drilling involves creation of a suitable drilling site and an access corridor. In upland areas, this involves clearance of vegetation from access roads and a 1- to 2-acre drill pad. Erosion of disturbed areas can reduce fertility, smother low-lying vegetation, abrade fish gills, and smother benthic organisms. In wetlands, dredging and filling of canals, ponds, roads, and pads can have extensive direct and indirect effects on vegetation and terrestrial and aquatic wildiffe.

Drilling and well testing require disposal of drilling mud, cuttings, brines, noncondensable gases, and organic condensate. A reserve pond for drilling wastes occupies several hundred to several thousand square feet, which must be cleared of vegetation and leveled. If nontoxic 
drilling muds are used, the results of leakage or Inundation of reserve ponds can be largely limited to siltation and turbidity as produced by erosion: If hot ibrines are disposed of by reinjection, impacts will result from the dredging of another pond or the filling or clearing of another pad and creation of another reserve pond. If evaporation ponds are used for brine disposal, salt and other evaporites may leach through faults in the lining or be washed out by abnormally high water and posstbly degrade local terrestrial and aquatic ecosystems. Salinity and thermal pollution problems may result from brine disposal Into natural waters. The impact of salinity would depend on the nature of the receiving water. If a large body of saline or brackish water was used for disposal and the brine was properly diffused, the impacts could be minimal because of the wide natural range of salinities to which the coastal aquatic biota is adapted. Thermal effects within the plume could result. Aquatic blota could be displaced, and dissolved oxygen would be lowered. Construction of canals or pipelines to carry the brine to the disposal site would result in destruction of vegetation, and leaks from these structures could contaminate water and kill vegetation.

Noncondensable gases (Sect. 4.1.2.1) are unlikely to accumulate to toxic levels because of the low production rate of a single test well, the Instability of air in this coastal region, and the absence of circulationrestraining topography! Precautions will be taken to ensure the health and safety of workmen. In most cases, flaring the gas should be acceptable. 
Workers will also be protected from the noise levels that could result from drilling and venting operations through the use of mufflers or ear protection. Noise and human activity, in general, would drive wildlife from the immediate vicinity of the operations.

While restoration following testing can be nearly complete in upland areas, it is unlikely that dredged and filled wetlands can be restored.

The impacts of field development and associated well testing w111 be the same as exploratory we11 drilling. Because impacts can accumulate within a limited area, mitigation would have to be more intensive to prevent large total impacts.

\subsubsection{Field development}

The impacts of field development are identical to those of test drilling but are cumulative in nature. Because of this, more stringent controls of erosion and fluid and gas release than are required during exploratory drilling may be necessary.

\subsection{RESOURCE UTILIZATION}

Potential environmental impacts of resource utilization will result from the construction of distribution systems and facilities associated with the use of geopressured geothermal energy, as well as with the maintenance and operation of such facilities. Electrical and nonelectrical 
development involves many simflar activities resulting in simflar impacts. However, there are significant differences between electrical and nonelectrical development, as described in the following sections.

\subsubsection{Pipeline construction}

Pipeline construction and malntenance will create an extensive network over several square kllometers. The plpeline network for electrical use of geothermal energy usually will be supported aboveground to allow design for plpe expansion. Pipe diameters may range from 25 to $60 \mathrm{~cm}$ (10 to $24 \mathrm{in.})$, and easements of 1.2 to $6 \mathrm{~m}$ ( 4 to $20 \mathrm{ft}$ ) may be cleared. Cut-and-fill techniques or landfill may be necessary in some instances.

Plping for nonelectrical use of geothermal energy will generally be underground, simflar to a utility system. Therefore, pipeline constructIon w111 Involve clearing, trenching, and backfilling. In both electrical and nonelectrleal development, pipeline construction will affect land, alr, and water quality. These effects will be temporary and can be minimized by proper construction techniques.

The construction of pipelines within salt marshes will create new engineering and environmental problems. Construction of aboveground lines would require extensive filling of marshland. Laying the pipeline In a dredged ditch, as is done by the 011 and gas Industries, would result in insulation and thermal expansion complications. 


\subsubsection{Physical effects}

Physical impacts of pipelines are simflar to those of field development with respect to erosion and possible land and water contamination. PIpeline construction will probably have an impact on land surface areas and on air, water, and visual quality; Increased nolse levels w111 occur. These effects will be temporary and can be mitigated by proper construction techniques. In association with electrical production, surface pipelines require an easement up to $6 \mathrm{~m}$ (20 ft) wide and should be locatec along roads, trails, or transmission line rights-of-way to minimize their impact. The steam or water lines will form a surface network and will disrupt 2.5 to $5.0 \mathrm{~km}^{2}$ (1 to $2 \mathrm{sq}$ miles) of area surrounding each 100-MW plant; the possibilities of erosion and land use impact are therefore extensive. Efforts to stabilize erosion and dust particles w11l be necessary. To monitor potential brine leakage and minimize land and water contamination, pipes will be elevated two to several feet above ground. Landscaping, vegetation restoration, and camouflaged pipes will lessen visual and aesthetic impacts. The presence of such facilities will probably restrict public access and recreational benefits in scenic and recreational areas. Although some surface uses are disrupted, grazing and agriculture may continue among the developed wells and pipelines.

Most pipelines associated with nonelectrical applications will be buried to lessen maintenance requirements and visual and land use impacts. The 
overall network may be more extensive than in electrical operations, and monitoring may be more difficult; thus, there is a greater possibility of brine leakage. Locating the lines along existing rights-of-way and reseeding the area after installation will minimize ultimate environmental effects.

\subsubsection{Biological effects}

The clearing of pipeline corridors will result in the temporary loss of most of the vegetation." Wildlife will be displaced from the corridor and adjoining areas, and this displacement will result in the death of many resident organisms due to loss of habitat. Erosion should not be a serious problem due to the flat topography of the affected region. Dust production could block the photosynthetic and respiratory surfaces of plants adjacent to the corridor.

Following recovery or replanting of vegetation, animals will reoccupy the right-of-way. Grasslands and agricultural lands should recover quickly. Forest yegetation will not be allowed to return. In its place, low vegetation will be maintained by cutting and/or use of herbicides. Unless carefully used, herbicides can affect nontarget organisms.

Because the method of pipeline construction in marshlands can not be predicted at this time, the impacts of such construction are also unpredictable. Construction will probably involve either dredging or filling. 
Pipelines may be ruptured during storm or flood conditions that could cause the release of brine before flow could be cut off. This situation could result in the localized loss of terrestrial or aquatic biota.

\subsubsection{Site preparation and plant construction}

The environmental effects of site preparation and plant construction will be similar to those of many other industrial construction projects. Site preparation will require the clearance of about 4 ha (10 acres) of 1and. Removal of vegetation, movement of earth, dredging, construction of temporary roads and bufldings, waste disposal, operation of construction vehicles, and other construction activities will also pose potential impacts.

\subsubsection{Physical effects}

The potential impacts of constructing a geothermal power plant include erosion, reductions in air and water quality, and changes in land use. Air pollution results from the operation of engines, burning, and particulate production from surface disturbances. S1ltation and turbidity of streams may Increase due to erosion, and water quality may be affected by accidental spills of lubricants, gasoline, or other substances. Changes in land forms and water channels may result from earth movement or dredging, and solid wastes from grading and construction will require proper disposal and stabilization. All these impacts can be minimized by proper construction techniques. 
During construction, land use will be temporarily or permanently categorized as Industrial development Public use of the land w11l be restricted in the immediate vicinity of the site, although multiple land uses may be possible after construction. It is likely that plants could be built on agricultural land in such a way that the total acreage lost would not be significant in most cases. If the plant is located near human habitation or an area of scenic or cultural significance, the visual and auditory impacts during construction are likely to be important. Their acceptability will depend on the magnitude of the impacts relative to local conditions.

\subsubsection{Blological effects}

Large-scale clearing of vegetation during construction will result in the loss of Individual plants and animals inhabiting the construction site. Nolse and other human activities w111 result in displacement of animals from an additional area; the amount of displacement varles directly with the density of the vegetation and inversely with the size of the animal. Erosion will decrease soil productivity and degrade aquatic systems. Dust production will be greatest in southern Texas, but will be least likely to have a significant impact on native vegetation. Filing and dredging of wetlands for plant construction will result in reduced productivity of both terrestrial and aquatic systems.

Further vegetational clearance may result if construction and human wastes are burled; if burned, air pollution may result. Alr pollution 
from the operation of engines will probably not produce a detectable biological effect. Disposal of liquid construction wastes (e.g., oils, concrete washings) could be a significant source of water pollution if not properly controlled.

These Impacts will be controlled by site-specific:mitigation measures and proper planning and construction techniques.

\subsubsection{Transmission line construction}

The Impact of transmission 1ine construction will depend on local topography and vegetation. Though similar to the effects described for pipelines (Sect. 4.2.1), the potential environmental impact of transmission line construction may be more extensive because of more extensive rights-of-way, road construction, and frequent maintenance.

\subsubsection{Physical effects}

The physical effects of transmission line construction will be similar to those described for pipelines (Sect. 4.2.1.1). Where lines cross low natural vegetation, soll disturbance will result from construction of access roads and tower bases. Access roads generally will be the major sources of soll movement because of the need for grading slopes and the rutting caused by equipment traffic. Access roads could also open new areas to recreational traffic, thus creating new opportunities for motorized recreation while increasing potential erosion and pressure on vegetation and wildlife. 
Towers and cleared rights-of-way wlll be highly visible and could be aesthetically unacceptable in areas of high natural or cultural value. Where transmission lines cross agricultural land, construction and maintenance may take land out of production. Locally, the lines and towers may affect the use of large agricultural equipment, rolling Irrigation systems, and aerial application of chemicals, but generally, they do hot serfously limit these activities.

\subsubsection{Biólogical effects}

The biological effects of transmission line construction include those described for pipelines (Sect. 4.2.1.2). Where the vegetation is low enough to pose no threat to the lines (coastal grasslands and agricultural lands), the potential biological impact is reduced by clearance of only the access roads and tower bases. It is unlikely that geothermal electrical production will require transmission lines of sufficiently high voltage to produce significant amounts of ozone, nitrogen oxides, or induced fields or currents. Plant-to-grid transmission lines are unlikely to have phases sufflclently close to create an electrocution hazard to eagles or othet large birds. Lines and towers may, however, create a locally signiflcant collision hazard for the large numbers of migratory and wintering birds attracted to salt marshes.

\subsubsection{Electrical production}

A typical plant size of $25 \mathrm{MWe}$ has been assumed for evaluating the environmental effects of plant operation. Impacts may result from geothermal 
fluid disposal, noncondensable gases, nolse, and cooling tower discharges. These effluents can affect land, air, and water quality and are described in Sect. 3.2.1.3. If uncontrolled, the groundwater and surface hydrological regime, water consumption, and potential subsidence and seismic activity may be affected by plant operation.

Operation of an electrical power plant will present potential impacts on land and water use; air and water quality; wildlife; vegetation; and scenic, historical, and cultural features. Possible environmental impact will be dependent, in part, on local conditions and the magnitude of plant operations.

\subsubsection{Physical effects}

The physical impacts of a geothermal plant may affect land and water use and air and water quality, and they may, induce subsidence and/or fault activitation.

Land use during the production pertod would be changed from agriculture, grazing, timber, fish and wildlife habitat, or recreation to industrial operations. A hypothetical 25-MNe plant would require 4 ha (10 acres) of land and an estimated 10 to 12 producing wells in the surrounding area. 1 The total land disrupted would therefore be a minimum of about $4.4 \mathrm{~km}^{2}$ (1.7 sq miles) per 25-MWe plant. Major scenic elements would be impaired because of the dominance of wells, power plants, pipelines, cooling towers, steam plumes, and transmission lines in the area. 
Industrial operations and restricted public access would further limit recreational, historical, and cultural uses. Agriculture, grazing, and timber activities would also be disrupted, but could continue on a reduced compatible basis.

During plant operation, withdrawal of geothermal fluids may cause the groundwater and surface hydrological regime to change and may influence water availability in the area. Approximately $55,485 \mathrm{~m}^{3}$ (45 acre-ft) of water per megawatt per year is lost at The Geysers from cooling towers. 2 often, this requirement is supplied by the condensate from geothermal operations; however, some local conditions and all binary systems will require the use of fresh water for cooling from local surface or groundwater sources. Additional water may be necessary for reInfection when significant volumes of steam are released to the atmosphere. The Impact of such withdrawal and possible thermal Impacts are of potential importance, particularly in localities where the water demand already exceeds groundwater recharge. When desalination is used, local water supply could increase.

Potential Impacts on local air and water quality also exist, depending on the effluents produced by the geothermal well. These effluents include geothermal fluid, noncondensable gases, noise, and cooling system discharges.

The chemical composition of geothermal fluids varies with each well (Table 3.1). Brine discharges at the surface may cause soll and water contamination and increases In stream turbidity and sediment load. 
During production, the transportation of large volumes of hot saline fluids will be necessary. Pipelines, open canals, or natural water channels may be used. When fluids are reinjected, pipelines from the plant to the disposal site will create relatively small environmental effects. The release of spent geothermal fluids to surface waters or land will require technical as well as legal evaluation on a sitespecific basis.

Transport of fluids in canals or natural channels may be used if the geothermal waters are disposed of offshore or in bays, lagoons, or estuaries. However, the possibility of effluent release is higher for open channel flow than for closed conduits. Systems of baffles or other mechanisms that increase turbulence and mixing w111 be necessary to promote cooling of the hot fluids. In addition, any open channels, temporary storage pits, or pits to retain accidental spills will require lining to seal them off from the surface alluvium in aquifer recharge areas. If evaporation ponds are used, the leaching of improperly discarded salts could alter soil and groundwater conditions. Groundwater sources may also be contaminated during the withdrawal and reinjection of fluids if isolation is not maintained by properly cemented production and injectionwell casing (Sect. 4.3).

Air quality during production may be affected by the escape of noncondensable gases associated with geothermal steam: carbon dioxide, carbon monoxide, hydrogen sulfide, methane, nitrogen, and ammonia.: Constituent composition and concentration will vary with each well; therefore, independent analyses may be required to determine which substances are 
present and how many exist at potentially toxic or nulsance levels (Sect. 5). Methane, hydrogen sulfide, amonia, and carbon dioxide are of primary concern. However, current compositional analyses of the gaseous effluents in geopressured reservolrs are Incomplete. Future studies may yleld other gases whose concentrations w111 pose environmental, safety; or health hazards:

Methane is clearly the most abundant noncondensable gas within the geopressured fluids." It is estimated that these waters w11l yleld an average of $40 \mathrm{ft}^{3}$ of natural gas per barrel of water. Because of its presence in such large volumes, the methane most 11kely will be isolated and stored for future use. Methane is lighter than air and generally will not collect localiy except during stagnant alr conditions. Eventually, methane w111 oxidize In the upper atmosphere. When not stored, methane and its contaminants (e.g., hydrogen sulfide) probably will be burned off; major products of the oxddation are carbon dioxide and water from the methane and sulfur dioxlde and sulfur trioxide from the hydrogen sulfide.

Hydrogen sulfide emissions assoclated with methane may be a major constituent of geothermal effluents. Characterized by a rotten-egg odor, hydrogen sulfide is considered a health and safety hazard at levels greater than $20 \mathrm{pPm}(0.002$ vol \%) and a nuisance at levels as low as $0.025 \mathrm{ppm}^{2}$ The diluted ambient air concentration w111 vary with each well and should be estrinated on a case-by-case basis. When vented to the air or burned off with the methane, the gas is readily oxidized to 
sulfur dioxide and sulfur trloxide. All three compounds are readily soluble in water and form a large number of different acids, including both sulfuric and sulfurous acid. Most of the gas and its products will be dispersed by adequate ventilation and ultimately will be washed out by raln, forming potentlally corrosive raindrops. However, hydrogen sulfide is slightly heavier than air and w11l accumulate to nuisance and toxic levels during stagnant air and alr inversion conditions.

Ammonia may also be present. It is characterized by a pungent odor and is regarded as toxic at levels of $50 \mathrm{ppm}\left(0,005\right.$ vol \%). ${ }^{2}$ Ammonia is lighter than air and will not collect locally, although it may have some impact during air inversion conditions. Readily soluble in water, ammonia will form ammonium hydroxide, which, ultimately returning to earth as rainfall, acts as natural fert1lizer.

Carbon dioxide is a major constituent (by volume) of the noncondensable geothermal gases and is considered toxic at a level of $5000 \mathrm{ppm}(0.5$ vol \%). ${ }^{2}$ Additional quantities may also be released to the atmosphere as a by-product of oxidized methane. Although adequate ventilation will lessen any major local impacts from carbon dioxide, the gas is of greater density than air and will collect in terrain depresslons during stagnant alr or alr inversion conditions.

Noise levels may vary during production, depending on the number and type of operations being conducted. Unless checked, the greatest levels of noise will be produced during drilling operations. other major 
factors Include the nolse from well venting operations [up to $100 \mathrm{~dB}(\mathrm{~A})$ at 15 m], mechanical-draft wet-cooling towers [up to $60 \mathrm{~dB}(\mathrm{~A})$ at $300 \mathrm{~m}$, as discussed later In this section, and overall electrical generation operations These factors are additive and could create high noise Intensities exceeding nulsance or pain threshold levels (Table 4.1) if uncontrolled.

In addition to land and water use and effluent impact, other effects develop as operations extend over several years. Wells will be abandoned and new wells will be drilled, tested, and prepared for production. The potential environmental impacts of these activities w111 be similar to those previously discussed in Sects, 4.1.2 and 4.2.2.

\section{Subsidence}

Production of geopressured water in Tertlary Gulf Coast sediments has the potential for causing land subsidence. Although geopressured flulds are not presently being produced, estimates of land subsidence can be made by simple mathematical models or by examining the subsidence attributed to ofl and gas production on the Gulf Coast.

Kreltler and Gustavson ${ }^{3}$ describe three Independent methods for estimating the amount of reservolr compaction. Two of these methods depend on (1) the sum total thickness of many thin mudstone layers within the sand aquifer and (2) the amount of pressure decline during production. The third method considers leakage from confining shale strata. 
The first method estimates potential compaction of geopressured mudstone by multiplying the cumulative mudstone thickness by the long-term (ultimate) decrease in porosity. If the initial and final fluidpressure-overburden ratios are known, the ultimate change in porosity can be obtained from Fig. 4.1. Table 4.2 tabulates the expected compaction at various pressure declines for three wells in the Armstrong field and a geopressured fairway of the south Texas Gulf Coastal plain.

The second method uses the concept of specific storage, which calculates potential compaction as the product of pressure decline and a constant of proportionality. 5 Application of this method leads to compaction estimates that are about $400 \%$ greater than those of the first method. It should be emphasized that compaction estimates will increase for greater mudstone thickness and pressure decline.

In the third method, Papadopulos et al., 6 using Hantush's "leaky aquifer theory,"7 estimated subsidence in an idealized conceptual reservoir. Subsidence is calculated by determining the compaction of the enclosing shales. An idealized reservoir is described in Table 4.3. It consists of a thick sand aquifer enclosed by upper and lower confining shale units. Although it was acknowledged that interbedded mudstones within the sand aquifer would be a factor, they were not considered in Papadopulos' estimate, which was considered crude. The time required for subsidence of the enclosing shales was about $10^{5}$ years. Predicted subsidence for the idealized reservoir ranged between 1 and $7 \mathrm{~m}$ for well 


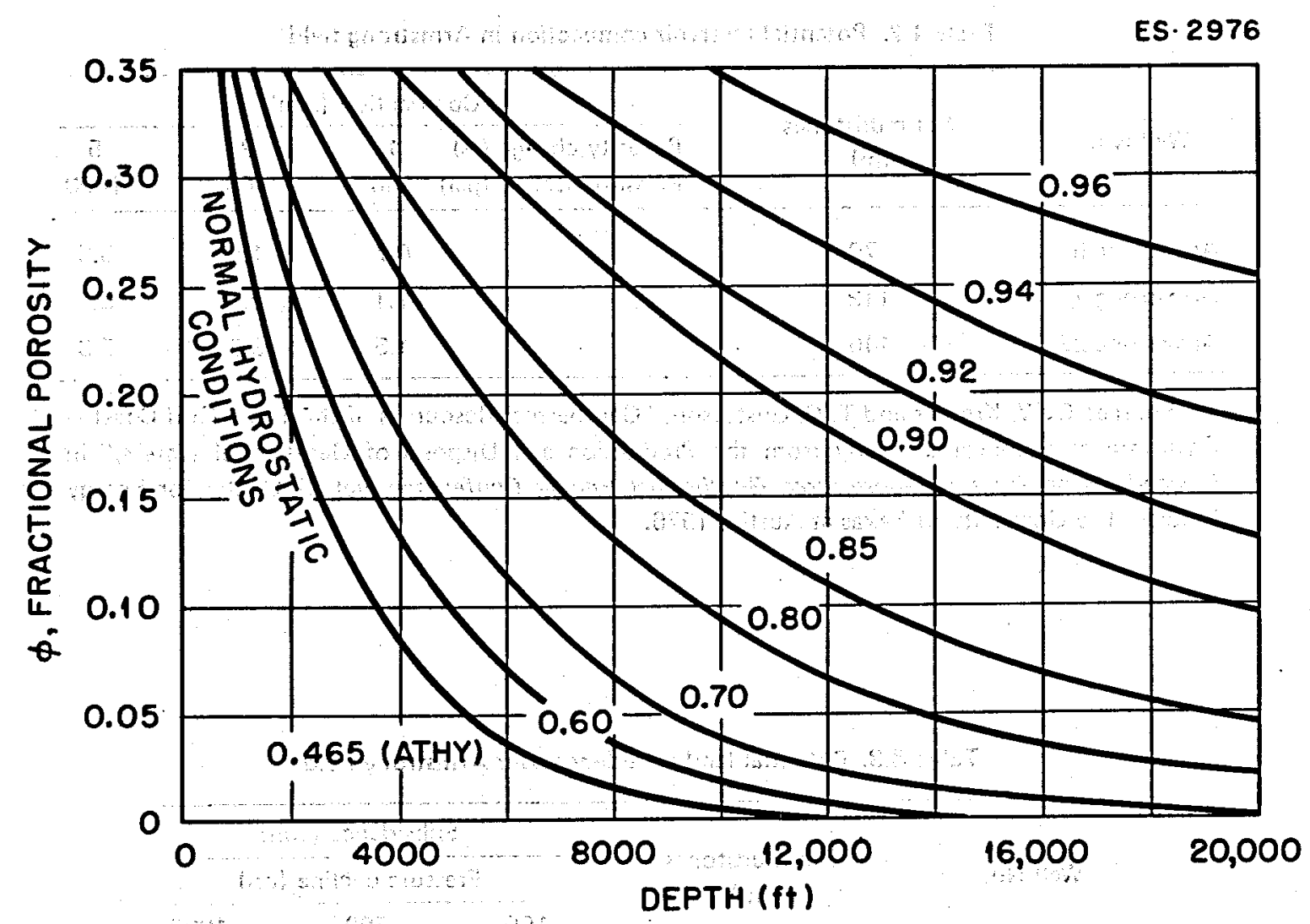

Fig. 4.1. Relationship between porosity and depth of burial for vartous yalues of $\lambda$ (fluid-pressure - overburden pressure rat1o) for an average shale or mudstone. Athy's curve $(\lambda=0.465)$ is assumed to represent "compaction equilibrium" condition. Source: C. W. Kreitler and T. C. Gustavson, "Geothermal Resources of the Texas Gulf Coast Environmental Concerns Arlsing from the Production and Disposal of Geothermal Waters," Proc. 2nd Geopressured Geothermal Energy Conference. Volume $V$. Legal, Institutional and Environmental, University of Texas, Austin, Feb. 23-25, 1976. 
Table 4.2. Potential reservoir compaction in Armstrong field

\begin{tabular}{|c|c|c|c|c|c|c|}
\hline \multirow[b]{2}{*}{ Well No. } & \multirow{2}{*}{$\begin{array}{l}\text { Net mudstones } \\
\text { (m) }\end{array}$} & \multirow{2}{*}{$\begin{array}{l}\vdots \\
\vdots \\
\vdots\end{array}$} & \multicolumn{4}{|c|}{ Compaction $(\Delta \mathrm{m})$} \\
\hline & & & $\begin{array}{l}\text { Porosity change ( } \%) \\
\text { Pressure decline (psi) }\end{array}$ & $\begin{array}{c}1 \\
100\end{array}$ & $\begin{array}{l}2 \\
500\end{array}$ & $\begin{array}{c}5 \\
1000\end{array}$ \\
\hline Armstrong 5 & 70 & & & 0.7 & 1.4 & 3.5 \\
\hline Armstrong 7 & 113 & & & 1.1 & 2.2 & 5.7 \\
\hline Armstrong 22 & 146. & & & 1.5 & 3.0 & 7.3 \\
\hline
\end{tabular}

Source: C. W. Kreitler and T. C. Gustavson, "Geothermal Resources of the Texas Gulf Coast Environmental Concerns arising from the Production and Disposal of Geothermal Waters," in Proceedings of Second Geopressured Geothermal Energy Conference, vol. 5, Center for Energy Studies, The University of Texas at Austin, 1976.

Table 4.3. Potential land subsidence over Armstrong field

\begin{tabular}{lcccc}
\hline Well No. & $\begin{array}{c}\text { Net mudstones } \\
(\mathrm{m})\end{array}$ & \multicolumn{3}{c}{ Subsidence $(\Delta \mathrm{m})$} \\
\cline { 4 - 5 } & & 100 & 500 & 1000 \\
\hline Armstrong 5 & 70 & 0.3 & 0.5 & 1.3 \\
Armstrong 7 & 113 & 0,4 & 0.8 & 2.1 \\
Armstrong 22 & 146 & 0.6 & 1.1 & 2.7 \\
\hline
\end{tabular}

Source: C. W. Kreitler and T. C. Gustavson, "Geothermal Resources of the Texas Gulf Coast - Environmental Concerns Arising from the Production and Disposal of Geothermal Waters," in Proceedings of Second Geopressured Geothermal Energy Conference, vol. 5, Center for Energy Studies, The University of Texas at Austin, 1976. 
spacings of 6 to $3 \mathrm{~km}$ respectively. These well spacings are very wide indeed. Papadopulos' estimates are for subsidence of an entire geopressured fairway using very wide well spacings, whereas Kreitler and Gustavson's compaction estimates ${ }^{3}$ for the Armstrong fleld were for localized areas surrounding conventionally spaced wells.

Kreitler and Gustavson belleve that compactional strain cannot be directly translated into land subsidence at the surface. Geertsma ${ }^{8}$ and Finol and Farouq $\mathrm{Ali}^{9}$ have shown that for equal amounts of reservolr compaction, land subsidence will diminish as the reservoir's lateral dimension decreases and its depth Increases. Table 4.3 gives the subsidence estimates for the corresponding compaction estimates of Table 4.2. Because the lateral dimensions of Papadopulos' 1dealized conceptual reservoir are very large in relation to depth, compaction can be translated more or less directly Into land subsidence.

Herrin 10 describes a fourth method for estimating compaction. He assumes that the major portion of compaction is caused by the compressib111ty of the sand aquifer. He estimates that; during the 20-year 11fe of a generating plant, the wellhead pressure will decline by 4375 psi for a 2640-ft-thick sand aquifer. Herrin assumes that two-thirds of the total compaction is caused by lateral pressures. Using this method, Herrin estimates subsidence to be $3.6 \mathrm{~m}(11 \mathrm{ft})$. 
The above discussion suggests that methods for estimating compaction are still a matter of debate and that a thorough compaction analysis should include elements of each approach.

The time frame for compaction should also be considered. Because the drainage path is very long and the permeability is very low, geologic time will be required for compaction of the enclosing shales to rin its course. The permeability of interbedded mudstones is also low, but the drainage path is short; hence, compaction of mudstones may be essentially complete in a few decades. Finally, compression of the sand aquifer takes place rapidly because of the high permeability. The above analysis contains uncertainties because little is known about the effect of exsolution of methane, osmotic pressure, and other molecular forces on the flow of fluids through fine-grained materials. 11 Thompson and Gray $^{12}$ reviewed rock mechanics theories for predicting subsidence. This approach assumes elastic behavior and a continuous region of subsidence. Gulf Coast sediments, however, do not behave elastically, and geopressured reservolrs are 1ikely to be terminated by growth faults. While rock mechanics might be a viable approach, soll mechanics seems to be more appropriate because it assumes plastic behavior of the substrata. Knapp and Isokrari ${ }^{13}$ describe the time dependency of reservoir performance; their methods could be used to predict subsidence as a function of time.

According to Christian, ${ }^{14}$ predictions of subsidence have been much smaller than the actual amount that subsequently occurred. He cites 
the Long Beach, California, o1l field as an example. Christian attributes problems in settlement prediction to (1) difficulties in obtaining undisturbed samples, (2) insufficient knowledge of the details of stratification, (3) uncertain fluld pressure measurements, and (4) uncertain estimates of silt compressibility.

There appears to be uncertalnty concerning the amount of pressure decline to be expected during the life of an electric generating plant. Herrin 10 anticipates a decline from geostatic to hydrostatic pressure (5000 psi or greater). On the other hand, Kreitler and Gustavson ${ }^{3}$ have not estimated compaction for pressure declines greater than 1000 psi. There does seem to be a tacit assumption that only a small percentage (3.5\% has been suggested by Herrin) of the total reservoir water will ever be used; that 1s; reservolr pressure w1ll never fall below hydrostatic pressure.

Dorfman and Kehle ${ }^{4}$ belleve, that, If abnormally pressured reservolrs are produced by depletion -rather than cycling, they are economical only if between 6 and $16 \%$ of the total water produced 15 derived from dewatering of Interbedded mudstones and Interstitial clays. This could lead to substantial subsidence. An example is the shale dewatering in the Pasadena section of Houston, Texas. 15 Subsidence exceeds $2 \mathrm{~m}$ (6 ft) - and exposes the naturally low-lylng area to extensive flooding. The Pasadena experfence is not analogous to the geopressure case because production was from a shallow groundwater aquifer. Nevertheless, it is 
a vivid example of the damage that can result from subsidence of populated areas within the Gulf Coastal plain.

According to Kreitler and Gustavson, ${ }^{3}$ ofl and gas production from the Chocolate Bayou field, south of Houston, caused a $30-\mathrm{cm}$ subsidence between 1942 and 1973. Production took place between -2438 and $-3962 \mathrm{~m}$. Much of the subsidence occurred during a period of maximum gas production (FIg. 4.2). The gas was produced from a geopressured zone; data for pressure decline were not given.

The effect of subsidence probably cannot be mitlgated. Evidently, no attempt to maintain reservoir pressure and mitigate subsidence by reinjection is under serious consideration. Presumably, reinjection into the geopressured reservolr against high wellhead pressure (5000 psi or more) is considered impractical, if not self-defeating, in the recovery of geopressured energy. Reinjection into a shallower, normally pressured aquifer may be feasible for disposal of waste fluid but it has doubtful merit as a subsidence mitigation measure. Perhaps it will be necessary to limit geothermal development to marshy regions, but even there the aquatic ecosystems are likely to be severely altered if subsidence occurs.

Tó summarize the above discussion, there is general agreement that subsidence can occur, but reliable estimates for subsidence have not yet been developed. Also, there are no known mitigating measures. Additional research on this subject is required. 


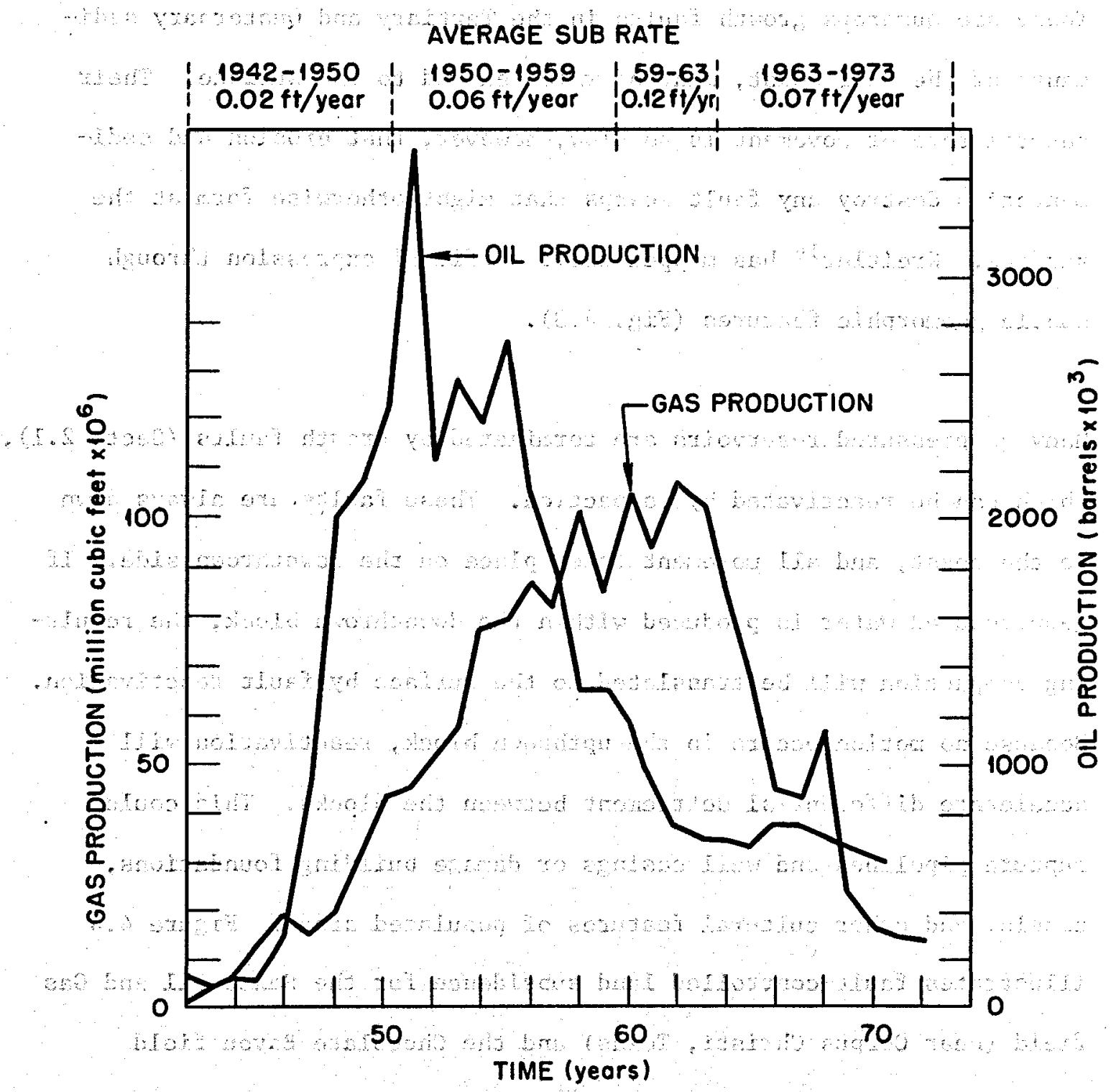

Fig. 4.2. Comparison of rates of subsidence to oil and natural gas production from Chocolate Bayou ofl fleld between the years 1942 and 1973. Production rates of ofl and gas from Texas Rallroad Commission. Source: C. W. Kreitler and T. C. Gustavson, "Geothermal Resources of the Texas Gulf Coast - Environmental Concerns Arising from the Production and Disposal of Geothermal Water's," Proc. 2nd Geopressured Geothermal Energy Conference. Volume V. Legal, Institutional and Environmental, University of Texas, Austin, Feb. 23-25, 1976 . 


\section{Fault act1vation}

There are numerous growth faults in the Tertiary and Quaternary sediments of the Gulf Coast, many of which extend to the surface: Their natural rate of movement is so slow, however, that erosion and sedimentation destroy any fault scarps that might otherwise form at the surface. Kreitler ${ }^{16}$ has mapped thelr surficial expression through subtle geomorphic features (FIg. 4.3).

Many geopressured reservoirs are terminated by growth faults (Sect. 2.1), which can be reactivated by compaction. These faults are always down to the coast, and all movement takes place on the downthrown side.- If geopressured water is produced within the downthrown block, the resultIng compaction w111 be translated to the surface by fault reactivation. Because no motion occurs in the upthrown block, reactivation will accelerate differential settlement between the blocks. This could rupture pipelines and well casings or damage building foundations, canals, and other cultural features of populated areas. Figure 4.4 illustrates fault-controlled land subsidence for the Saxet 011 and Gas fleld (near Corpus Christi, Texas) and the Chocolate Bayou field mentioned in Sect. 4.2.4.1.

\section{Reinjection problems}

Reinjection will be considered primarily for the purpose of fluid waste disposal. The principal investigators $3,10,17$ propose to reinject waste fluids into shallow saline aquifers. 


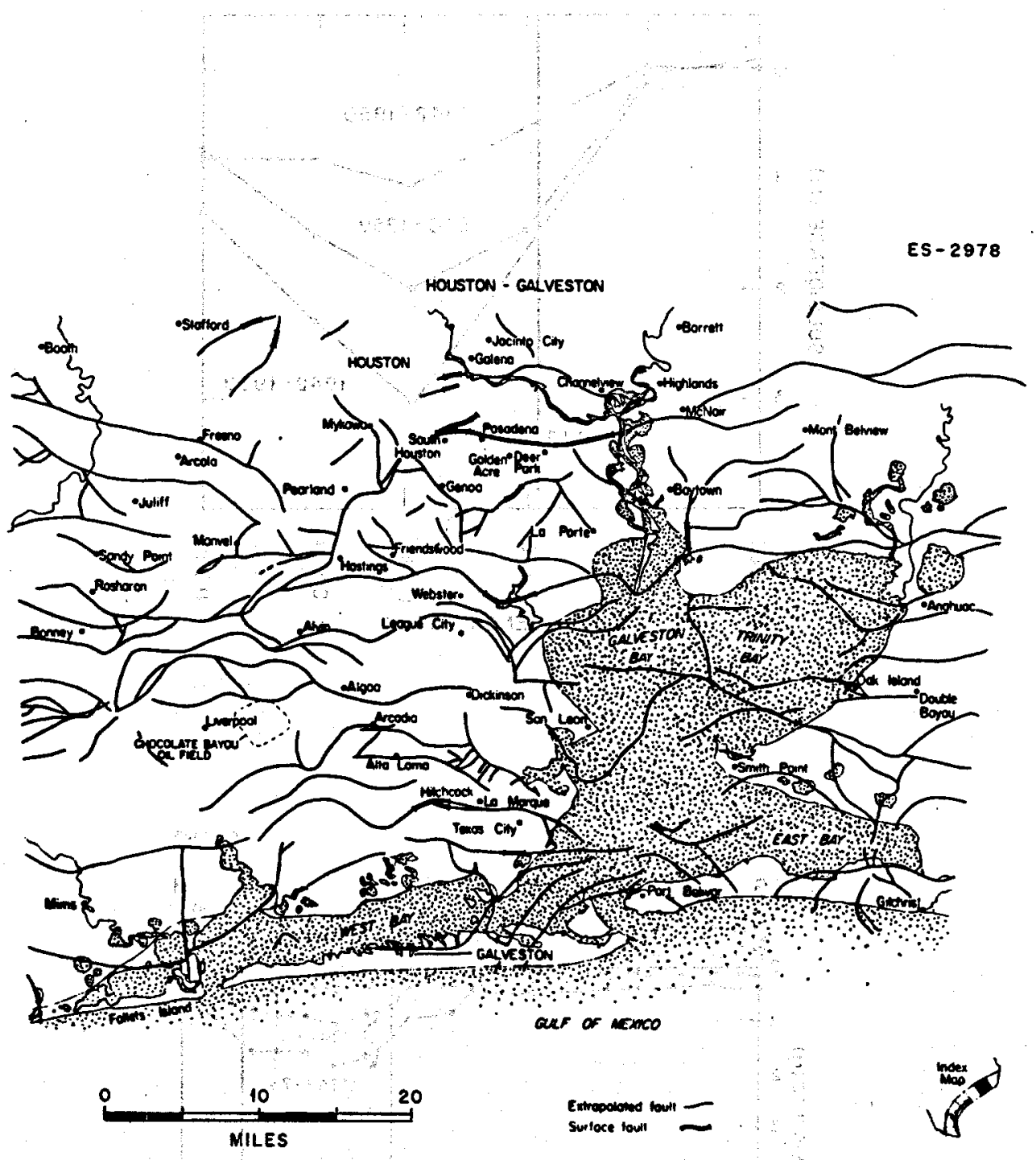

Fig. 4.3. Coincidence of active surface faults with surface traces of extrapolated subsurface faults, Houston-Galveston area. Note location of Chocolate Bayou 011 and gas fleld. Source: C. W. Kreitler and T. C. Gustavson, "Geothermal Resources of the Texas Gulf Coast Environmental Concerns Arising from the Production and Disposal of Geothermal Waters," Proc. 2nd Geopressured Geothermal Energy Conference. Volume V. Legal, Institutional and Environmental, University of Texas, Austin, Feb. 23-25, 1976 . 

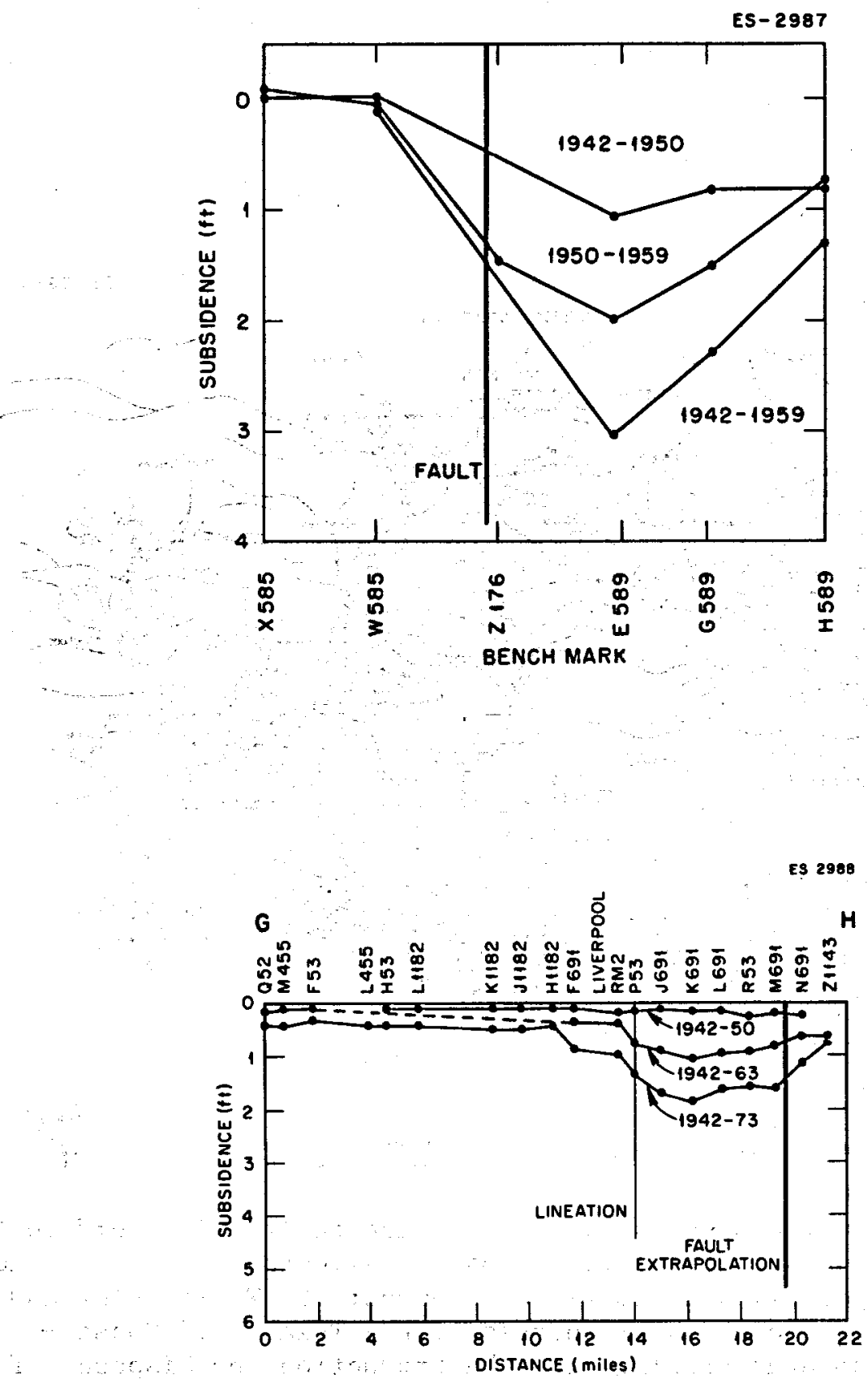

Fig. 4.4. Fault-controlled land subsidence for the Saxet and Chocolate Bayou 011 and Gas fields. (a) Land subsidence over Saxet oil and gas field, Corpus Christ1, Texas. Benchmark 589 over the center of the field. Note fault control of subsidence (between B. M. W585 and 2176). (b) Land subsidence over Chocolate Bayou oil and gas field. Note coincidence of differential subsidence with lineation and surface trace of extrapolated subsurface fault (see for field location). Source: C. W. Kreitler and T. C. Gustavson, "Geothermal Resources of the Texas Gulf Coast - Environmental Concerns Arising from the Production and Disposal of Geothermal Waters," Proc. 2nd Geopressured Geothermal Energy Conference. Volume V. Legal, Institutional and Environmental, University of Texas, Austin, Feb. 23-25, 1976. 
Aquifers deeper than $1000 \mathrm{~m}(3000 \mathrm{ft})$ but above the geopressured zone are considered to be the best avallable areas for reinjection because of their presumed high salinity. A number of highly saline sand bodies are available at Intermediate depths. ${ }^{4,11}$. Furthermore; Schmidt ${ }^{18}$ states that geopressured waters of the Manchester fleld, Loulsiana, are moderately saline $(16,000$ to $26,000 \mathrm{mg} / 1$ ter TDS), but are less saline than overlying normally pressured water (600 to $180,000 \mathrm{mg} / 11$ ter TDS). Herrin 10 reports low salinity (2000 to $6000 \mathrm{ppm}$ ) in the geopressured zones of south Texas but about 20,000 ppm (less than normal seawater) near Corpus Christ1.: Dorfman and Kehle maintain that diagenetic changes of montmorillonite to 111 ite at temperatures above $120^{\circ} \mathrm{C}$ release freshwater from enclosing shales, which decreases the salinity of the geopressured sand aquifers. Magaral9 attributes this freshening to Ion filtration by clay minerals as the water (released from montmorillonite) passes through the shale.

Kreitler and Gustavson ${ }^{3}$ caution against the assumption that low to moderate salinity will prevail In all geopressured zones. They point out that contamination from nearby salt domes might produce a highly saline aquifer. Halbouty 20 states that salt domes are numerous east of Houston, Texas, On the other hand, no salt domes have been found west and south of Corpus Christ1, except near the Rto Grande River.

A commercially viable generating factlity w1ll require between five and ten wells, each producing $34,000 \mathrm{bbl} / \mathrm{day}, 3$ which must be disposed of. 
In theory, reinjection would seem to be the most environmentally acceptable means of disposal. The fluids would have an impact only on the Imediate surroundings of the geothermal plant. Other alternatives, such as disposal in estuaries, coastal bays, lagoons, and open sea, require pipelines and canals which extend the affected area (Sect. 4.3.5). Furthermore, these areas might be unacceptable sites for disposal because of the high temperature and salinity of the waste fluids.

Reinjection will require extensive exploration of the disposal aquifer to determine feasibility. According to Kreftler and Gustavson, 3 $15 \times 10^{6} \mathrm{bbl}$ of saline ofl-field waters were disposed of by reinjection in Matagorda County, Texas, during 1961. This is equivalent to one month's production of geopressured fluid for a single electrical generating site. Injection depths for 43 wells ranged from 450 to $2165 \mathrm{~m}$ (1480 to $7100 \mathrm{ft}$ ), with injection pressures ranging from 0 to $1000 \mathrm{psi}$. Only two of these wells had high disposal rates: (1) $6000 \mathrm{bbl} /$ day at 800 psi and (2) $10,000 \mathrm{bbl} /$ day at $300 \mathrm{psi}$. Many reinjection wells require high-surface pressures to dispose of relatively small volumes of water. One well required $800 \mathrm{psi}$ to dispose of $150 \mathrm{bbl} / \mathrm{day}$. At the highest reported disposal rate, 20 to 40 disposal wells would be required per generating site. According to Dorfman and Kehle, 4 the East Texas Field-Salt Water Disposal facility reinjects $540,000 \mathrm{bb} 1 /$ day (6000 bb1/we11). This facllity serves the largest gas field in North America. A single 100-MW plant producing between 200,000 and $400,000 \mathrm{bb} 1 /$ day would require between 35 and 70 disposal we1ls. 
In an article ent1tled "Brine Disposal," an anonymous author stated that two drilling and service organizations believe that a reinjection rate between 20,000 and 35,000 bbl per day per well is technically feasible. There was no indication as to how this could be done. The author Implied that oll companies have never developed the capability because there has been no apparent need for such high reinjection rates. 21 In any event, if the disposal reservoir is not well explored, full-scale production may result in surface sp1lls or plant shutdown.

Furthermore, scaling of reinjection wells and plugging of aquifers is likely to develop as a function of time. Silica, calcite, and anhydrite are the principal scaling agents in geothermal fluids.22 Exsolution of carbon dioxide gas at reduced pressure and mixing with more alkaline waters will decrease the solubility of calcite.

It might be feasible to mitigate disposal problems by desalination. ${ }^{4}$ Desalination has been proposed for the south Texas Gulf Coast plain where a genuine need exists. 23 Carlson et al. ${ }^{23}$ belleve that desalinated water will not be competitively priced in the near future.

\subsubsection{Blological effects}

The biological effects of electrical production are direct products of the effects on air, so11, and water quality described in Sect. 4.2.4.1 and the loss of habitat described in Sect. 4.2.2.2. Habitat loss will 
be somewhat less than that during the construction period because of the reestablishment : of vegetation and the reduction of human activity.

The effects of the use and disposal of geopressured fluids depend on the content of the fluids and methods of handling. Analyses of actual geopressured resource fluids are unavailable, but analyses of water from within the geopressured zone indicate a wide range of chemical composition. The concentrations presented in Table 3.1 are typical but incomplete and therefore do not represent elther an average or an extreme case. Salinities are generally believed to range from moderate to high ( 8000 to 72,000 ppm TDS)..$^{3}$ However, Dorfman and Kehle ${ }^{4}$ Interpret electrical logs as indications that geopressured reservolrs will yield relatively fresh water (TDS $<5000 \mathrm{ppm}$ ), which could be used for irrigation after minor desalination.

As described in Sect. 4.1.2, geopressured fluids may be disposed of in natural water bodies, by evaporation, or by reinjection. Construction of evaporation ponds would require destruction of a potentlally large area of vegetation. Such ponds would support only the most salt- and heat-tolerant planktonic species and, because of leaks and possible inundation during storms and floods, may contaminate surface and groundwater. The use of permanent evaporation ponds is now barred by the Texas Water Quality Board. ${ }^{3}$

Disposal into natural water bodies is potentially feasible. Problems of saline toxicity could be overcome by diffusing the wastewater into a 
- large coastal water body. The biota of these waters 1 s adapted to wide

natural variations in salinfty. Unless wastewaters are cooled before disposal, their release Into surface waters is likely to violate Section 316 of the Federal Water Pollution Control Act of 1972 and related state regulations. The ocean and large bays may provide heat sinks of adequate size to prevent damage to blota, but in some areas of geopressured resources, surface temperatures of coastal waters may naturaily exceed súgested maximum ambient temperatures. 5 Wastewater can be carried to the disposal site in pipes, ditches, or natural channels. Pipes can be laid on the ground surface, buried, or sunk in a dredged channel. No major effects should occur due to the operation of a plpeline uniess a leak or break occurs. Until the leak is discovered and the plant shut down, the hot saline water could k111 vegetation and aquatic organisms. Saline water would leak through the banks of open wastewater channels, and the channels would eventually become bordered by salt-tolerant vegetation. Such channels would próbably not support a macroścóplc aquâtlc blota unless they were long enough-to allow the water to cool ratos

Disposal of wastewater in saline aquifers cán reduce both toxic effects and the potential for subsidence. Although this method would require the drilling of additional wells (see sect. 4.1.2), no significant biologlcal effects should result from routine operation.

Because of the absence of alr-restraining terrain features and the general Instability of coástal air, natural gas releases should not be 
serious. Because methane is combustible as well as toxic and will probably be collected at the plant site, it poses a potentlal health hazard to workers. Precautions similar to those undertaken at natural gas production sites will be instituted as required.

The continuous noise associated with an operating plant will not Ilkely have a significant effect on wildlife. The general level of human activity will have more effect than the noise level In preventing use of the plant area by wildlife.

The biological effects of condenser cooling will result from salt drift, fogging, blowdown disposal from towers and ponds, and impingement, entrainment, and heating from once-through cooling.

Drift of salts from towers and spray ponds may affect sensitive plants in a localized area around the tower. The amount of drift deposition and the area affected will depend on the size of the generating factilty. Agricultural crops will be of primary concern, particularly where irrigation has resulted in salination of soils. Salt marshes and other coastal vegetations are adapted to high levels of airborne salt.

Release of water vapor from towers and ponds is unlikely to have significant biological effects.

If blowdown is not reinjected, it must either be evaporated in holding ponds, which would result in salination of soll; or released to natural 
water bodies. In addition to concentrated minerals, blowdown can contain biocides and chemicals to control corrosion, scaling, and hydrogen sulfide. This water is potentially toxic, and its release must be carefully controlled.

The use of once-through cooling for geothermal plants is potentially less damaging than it is for a coal-fired or nuclear plant because the smaller size of geothermal plants and lower steam temperatures could make lower intake velocities possible, with reduced entrainment and impingement mortality and reduced thermal effects in the receiving water. However, this cooling method is potentially the most damaging to aquatic systems, and the requirements of Sect. $316 a$ and $b$ of the Federal Water Pollution Control Act of 1972 have greatly reduced its use. Once-through cooling is most frequently used where large bodies of water are avallable.

As discussed in Sect 4.2 .4 .1$, land surface subsidence is a posstble result of geopressured resource development. Subsidence could easily result in the conversion of coastal marshlands to permanently aquatic wsystems. Loss of marshland decreases habitat avallable for the many in wldife species that inhabit it (Sect. 2:4). Marshlands are also an b) Important economlc resource as fish breeding grounds, sources of nutrient Input to coastal ecosystems, and directly as shrimp fisheries and other commercial and sport Industries. This loss would not be entirely replaced by subsidence of new land to the level of tidal inundation because of the use of idkes along the upper edge of marshes. It is possible, but 
less 1 ikely, that subsidence would affect other vegetations $(e . g .$, riparian forests) due to changes in water level.

\subsubsection{Nonelectrical applications}

Nonelectrical uses of geothermal energy include residential and commercial uses, agricultural uses, industrial process uses, and balneology. The results of drilling and construction of the pipeline distribution system have been considered in previous sections. Renovation of existing utilization systems for nonelectrical geothermal energy or construction of new utilization systems designed for nonelectrical applications will be required.

The geothermal reservoir must be located near the resource user to use geothermal energy economically for nonelectrical purposes. As geopressured reservoirs suitable for nonelectrical applications are 1dentified, industrial, commercial, and residential developments will be constructed in the vicinity of the geothermal fields. Some of these reservoirs are not now located near developed areas.

Environmental impacts of fluid extraction and distribution for nonelectrical geothermal applications are essentially synonymous with those for electrical applications, with the exception that pipeline systems would likely be much longer: with increased complexity for fluid distribution. However, the extent of the effect will depend on location conditions, the nature of the use, and the methods employed. Nonelectrical energy production may stimulate secondary industrial, commercial, and residential development; the effects of this growth will depend on local factors. 
In addition to the Impact created by developed sites of geopressured geothermal productlon; Industrial or egricultural complexes constructed in these regions may increase the impact on land, air, and water quality as well.

\subsubsection{Physical effects}

Physical effects of nonelectrical applications are simflar to those of electrical production (Sect. 4.2.4.1), but generally they create less extensive impacts. Prior to operation, the exploration, driling, and development of wells specifically for nonelectrical operations will be similar to that for electrical production, although some wells may be drilled at shallower depths.

The extraction and use of geopressured flulds for nonelectrical uses Involve Impacts similar to those for electrical production - waste disposal, thermal contamination, and possible subsidence and Induced selsmicity. Piping will be more extensive and therefore may create a greater potential for leakage of brines. Much of the piping will be subsurface, thus minimizing aesthetic impacts. Deaerators will be necessary to remove dissolved gases prior to transportation of the geothermal fluid; this w111 also contribute to nolse and aesthet1c impacts and could reduce alr quallty. Because current technology has little experience in the long-distance piping of hot water, posslble safety hazards may exist when high-temperature water is pumped under pressure over large areas. 
A wide range of potential nonelectrical uses is possible (Sect. 3.2.2.1). The most common uses now and in the Immedlate future are space heating for homes and commercial structures and heat and water sources for greenhouses. Both uses employ relatively low-temperature fluids which can be carried by buried pipelines. In urban areas, these pipelines can follow existing ut1lity rights-of-way and avoid significant physical and aesthetic impacts. Gas leaks from pipes could result in reduced air quality.

Other nonelectrical uses of hydrothermal energy include aquaculture, desalination, Industrial heat, and warming feedlots and other animal culture systems. As the cost of other forms of energy increases, Industries could be attracted to areas of geopressured geothermal regions that are not currently industrlalized. Because of stimulated Industrial activities and increased population density, local reductions In afr and water quality may result and water availability may be reduced.

\subsubsection{Equipment development}

Because the power cycles and drilling techniques will be similar for all geothermal resources, most results of the extensive equipment development program belng carried out for the hydrothermal resource development will be directly applicable to development of geopressured resources. These include extensive heat exchanger and total-flow 
system research as well as down-hole testing devices and other equip-: ment. The principal resource-specific equipment needs are pressureresistant drilling and well completion equipment, gas separators, and a hydraulic turbine. Equipment development projects could be carried out by universities, private laboratories, or national laboratories. No testing sites have been designated.

Impacts associated with the testing of such equipment will be similar to those of the operation of a hydrothermal electrical generating plant except that the tests w1ll be shorter and will probably have fewer operational impacts. Test facilities will have to be refitted period1cally for new experiments and for performance testing. During testing of new equipment, there may be a greater likelthood of escaping geothermal fluids or other accidents.

\subsection{ACCIDENTS}

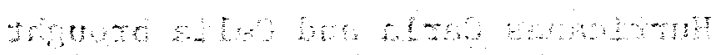

Accidents are defined in this report as unplanned events that may occur naturally or result as a by-product of geothermal resource development. - Unexpected subsidence, natural hazards, earthquakes, casing fallures, and blowouts are examples of accldents as defined above.

The effects of subsidence have been addressed in Sect. 4.2. A discussion of environmental concerns arising from the production and disposal of geopressured waters is presented by Kreltler and Gustavson. 3 Much of the material in Sect. 4.3 is extracted from their work. 


\subsubsection{Natural hazards}

Kreitler and Gustavson ${ }^{3}$ 1ist several natural hazards that are significant in geopressured fairways of the Gulf Coastal plain. Among these hazards are shoreline erosion, stream flooding, hurricane flooding and winds, and expansive soils. These hazards have the potential for damaging geothermal installations, and in the case of flooding, they are aggravated by subsidence. Damage to geothermal installation by natural hazards may result in leaks, spills, and because methane gas is present, fire.

Kreitler and Gustavson ${ }^{3}$ provide data on the frequency of occurrence and Intensity of floods along the Texas Gulf Coast. The Colorado River of south Texas has completely filled its floodplain about once every nine years since 1913, and the Nueces RIver has covered 1ts floodplain about once every 4.25 years for the past 56 years. Since 1912, 12 storms with hurricane force winds (119.4 kph or $74 \mathrm{mph}$ ) have struck Corpus Christi and surrounding geothermal fairways. Hurricanes Carla and Cella brought winds of $242 \mathrm{kph}(150 \mathrm{mph})$ and $282 \mathrm{kph}(175 \mathrm{mph})$ to portions of these fairways. Hurricane Beulah produced 11 tornadoes in the vicinity of the Corpus Christi fairway and was accompanted by $76.8 \mathrm{~cm}$ (30 in.) of rain. Hurricane storm surges as high as $6.7 \mathrm{~m}$ (22 ft) can be expected. Much of the Texas Coastal plain is less than $25 \mathrm{ft}$ above sea level and thus is vulnerable to flooding (Fig, 4.5).

Sediments of the Texas Coastal plain have a high content of expansive clay soils. The dominant clay mineral in these soils is montmorillonite 


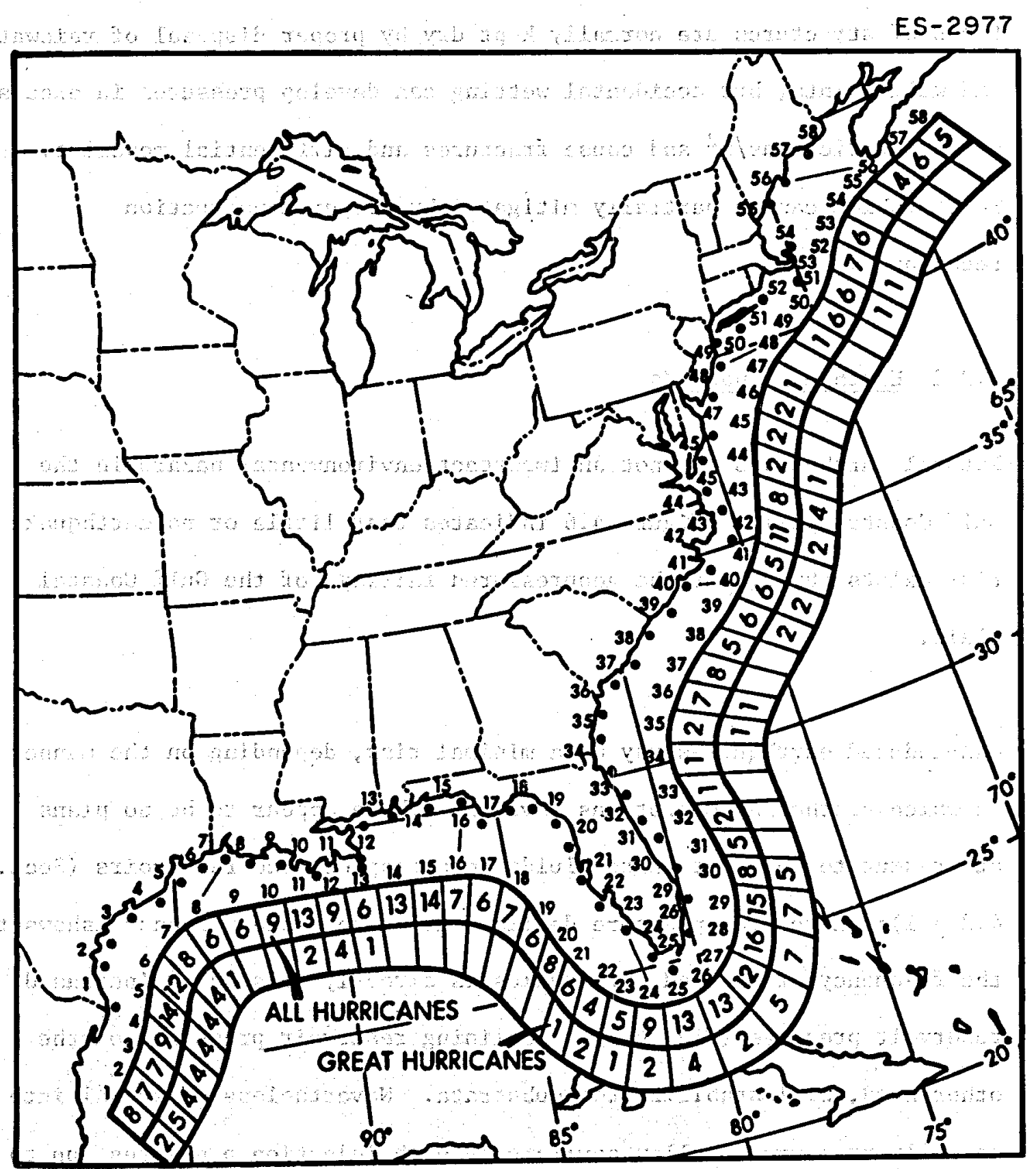

Fig. 4.5. Probability (percentage) that a hurricane (winds exceeding $73 \mathrm{mph}$ ) or great hurricane (winds exceeding $125 \mathrm{mph}$ ) will occur in any one year in 50 -mile, segment of the coastiline. Source: R. H. Simpson, and M. B. Lawrence, Aticantic Hurricane Frequencies Along - the U.S. Coastiine, NOAA Tech.Memo. \#NWS SR-58, U.S Dept. of Commerce, Washington, D.C., 1971. 
whlch expands upon wetting and contracts upon drying. The buried foundatIons of structures are normally kept dry by proper disposal of rainwater and well points, but accidental wetting can develop pressures in excess of 142 metric tons $/ \mathrm{m}^{2}$ and cause fractures and differential movement. This problem can be partially mitigated by proper construction techniques.

\subsubsection{Earthquake hazards}

Natural earthquakes are not an important environmental hazard in the Gulf Coastal plain. Figure 4.6 indicates that little or no earthquake risk exists throughout the geopressured fairways of the Gulf Coastal plain.

Man-induced earthquakes may be a minimal risk, depending on the manner In which geothermal operations develop. There appear to be no plans at present to reinfect waste fluids into geopressured reservoirs (Sect. 4.2.4.1); therefore, pressure decline will take place. Evans ${ }^{24}$ shows that the frequency of induced earthquakes is directly related to Increased reservoir pressure (Fig. 4.7). Decllning reservoir pressure, on the other hand, w111 stabilize the substrata. Nevertheless, disposal into normally pressured shallow aquifers at high injection pressures (up to 1000 psi) (Sect. 4.2.4.1) is seriously being considered. Reinjection at high pressure into shallow aquifers, in combination with compaction of the geopressured reservoir, might reactivate growth faults (Sect. 4.2.4.1) 
(4)

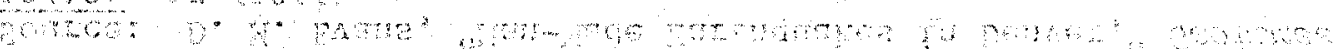

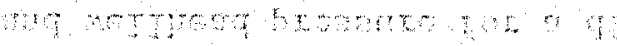
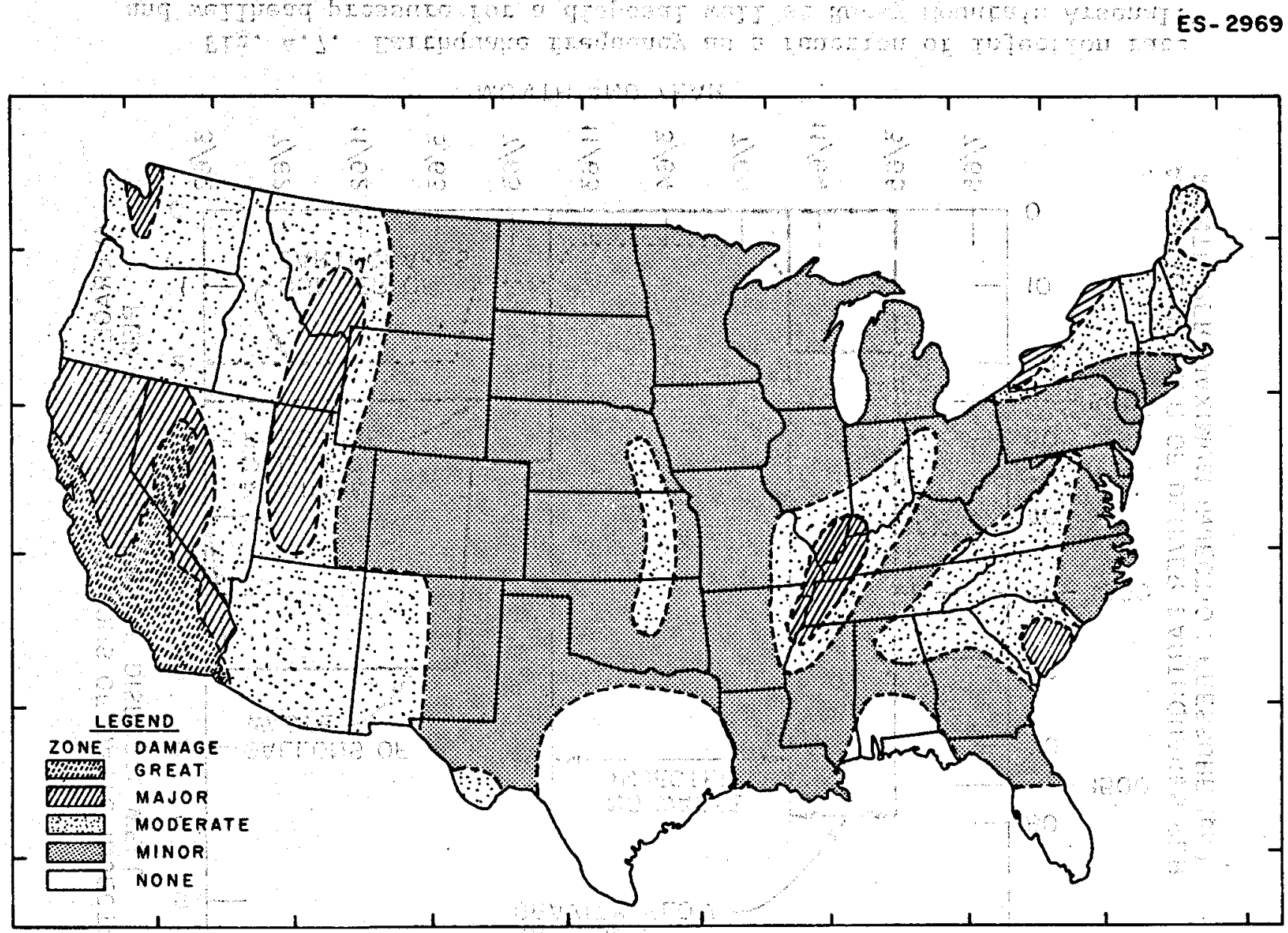

Fig. 4.6. Seismic risk map of the United States. Source: Wyle Laboratories, Scientific Systems and Services Group, E1 Segundo, Calif. Seismic data taken from TM 5-809-10/NAVFAC P-355/AFM 88-3, Chap. 13. 


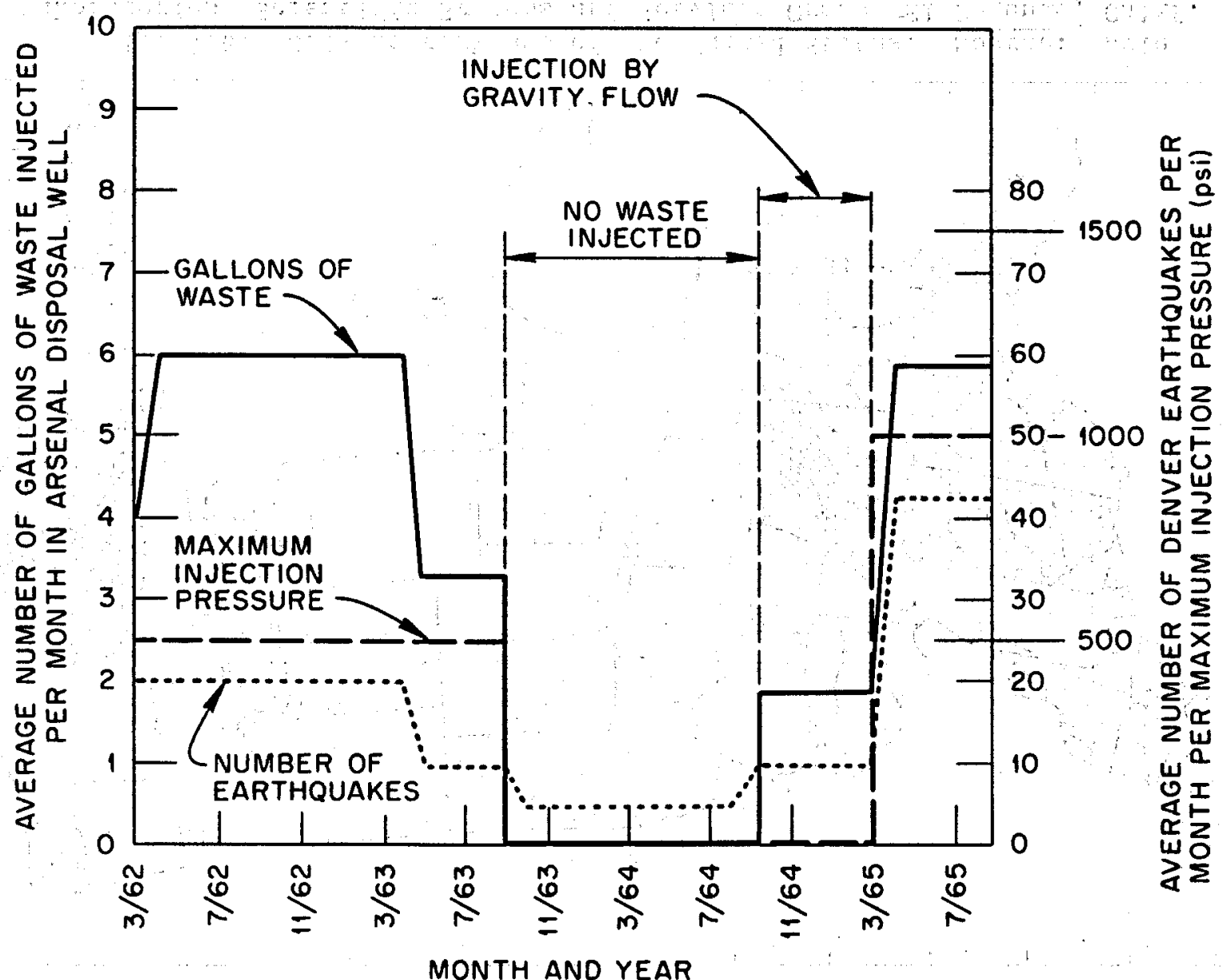

Fig. 4.7. Earthquake frequency as a function of injection rate and wellhead pressure for a disposal well at Rocky Mountain Arsenal. Source: D. M. Evans, "Man-Made Earthquakes in Denver," Geotimes 10(19): 17 (1966). 
Reactivation of growth faults does not necessar1ly 1mply that the r1sk of seismic damage will increase. Numerous growth faults of the Gulf Coastal plain are of Tertiary to Holocene age. Many of them are probably st111 active. Strong earthquakes have not been recorded in this region because the strata along the fault zones are too weak to accumulate significant quantities of strain energy. Slippage along reactivated faults might be accompanied by microearthquakes that are below the threshold of detectability. Human awareness of this slippage w11l be expressed subtly in terms of gradual subsidence.

\subsubsection{Ruptured casing}

Casings may rupture during the production stage in two ways: (1) subsidence and fault activation related to withdrawal of fluids and (2) corrosion. A cement liner around the casing is intended to contain the fluids if a casing failure occurs. However, large displacement along a reactivated growth fault (Sect. 4.2.4.1) could also rupture the lining. Furthermore, hot acidic brine will decompose most cements over a period of time. The Gulf coast oil industry has not experienced major problems with destabilized field wells along reactivated growth faults. The Industry also has little experience with the copious quantities $(40,000$ $\mathrm{bb1/day/we11)} \mathrm{of} \mathrm{fluid} \mathrm{to} \mathrm{be} \mathrm{withdrawn} \mathrm{through} \mathrm{geothermal} \mathrm{operations.}$ If the casing ruptures in a groundwater aquifer, contamination of potable water and waste of geothermal energy will undoubtedly occur because the

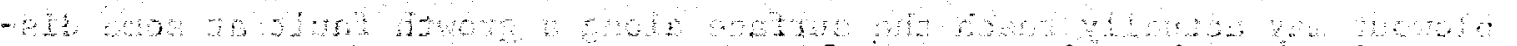
reservoir fluids are geopressured. If rupture takes place in the enclosing shale or in a highly saline aquifer overlying the geopressured 
zone, IIttle or no damage to the environment will result. In the latter case, geothermal energy would be wasted, and in any case, the well would have to: be recompleted.

\section{3 .4 Blowouts}

Blowouts can occur during exploratory drilling, field development, or full-scale production. Although the petroleum industry has developed sophisticated blowout prevention equipment against any known eventuality, malfunctioning equipment, human error in judgment, or negligence occasIonally can lead to blowouts. Kaufman 25 writes:

Geopressured zones have been expensive nuisances to the oil and gas producers. In earlier days blowouts were frequent, and objectives which involved drilling through overpressured zones were delicately abandoned. The problem has been greatly studied and techniques for predicting and penetrating through such zones are now avallable. (But no driller likes to play around with the hazard because of the high pressures and temperatures encountered.)

Blowouts are most 11kely to occur during exploratory drilling when little is known about reservoir conditions, but they also occur during field development. During full-scale production, they are most 1ikely to occur when workover rigs are replacing worn-out casing.

Blowouts can also occur if the casing ruptures at a shallow depth. The blowout may actually reach the surface along a growth fault at some distance from the well site. Blowouts caused by casing or blowout preventor fallure are controlled by cement injection through directional rellef we11s. 
Directional relief wells do not completely solve the problem of blowouts. They take time to drill, and the cement and grouting operations are $\operatorname{cosec}-3$

often less than satisfactory. For example, a shallow offshore Loulsiana well blew out uncontrollably from a geopressured zone at $13,900 \mathrm{ft}$, yielding hot salt water at a rate estimated between 80,000 and 400,000 $\mathrm{bb} 1 /$ day until it was finaliy brought under control, after about one month. 25 Another well in Vermilion Parish, Louisiana (near the site of a proposed geopressured pilot project), blew out in July 1971 under a wellhead pressure of $4000 \mathrm{psi} .15$ After $10 \mathrm{hr}$, the well caught.fire (presumably by combustion of methane) and could not be capped. The well was brought under control four months later by pumping cement through a directional rellef we11. A leak developed, and in another four months, the well blew again. pischarge of brine continued for two years before the well was brought under control through a worked-over rellef well. The blowout was caused by a technical error tn handling surface equipment rather than by an encounter with uncontrollable subsurface conditions.

Berman $^{26}$ discusses conditions that lead to blowouts in geopressured wells. Many of the following Ideas are extracted from his text.

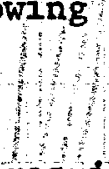

Very careful planning, is required to prevent a blowout in a geopressured zone. Figure 4.8 illustrates some important considerations that vary with depth: (1) predicted pore pressure in equivalent mud weight, (2) drilling mud and casing spectfications, and (3) predicted driliing mud weight that produces hydraulic fracturing of the wall rock. On Federal 


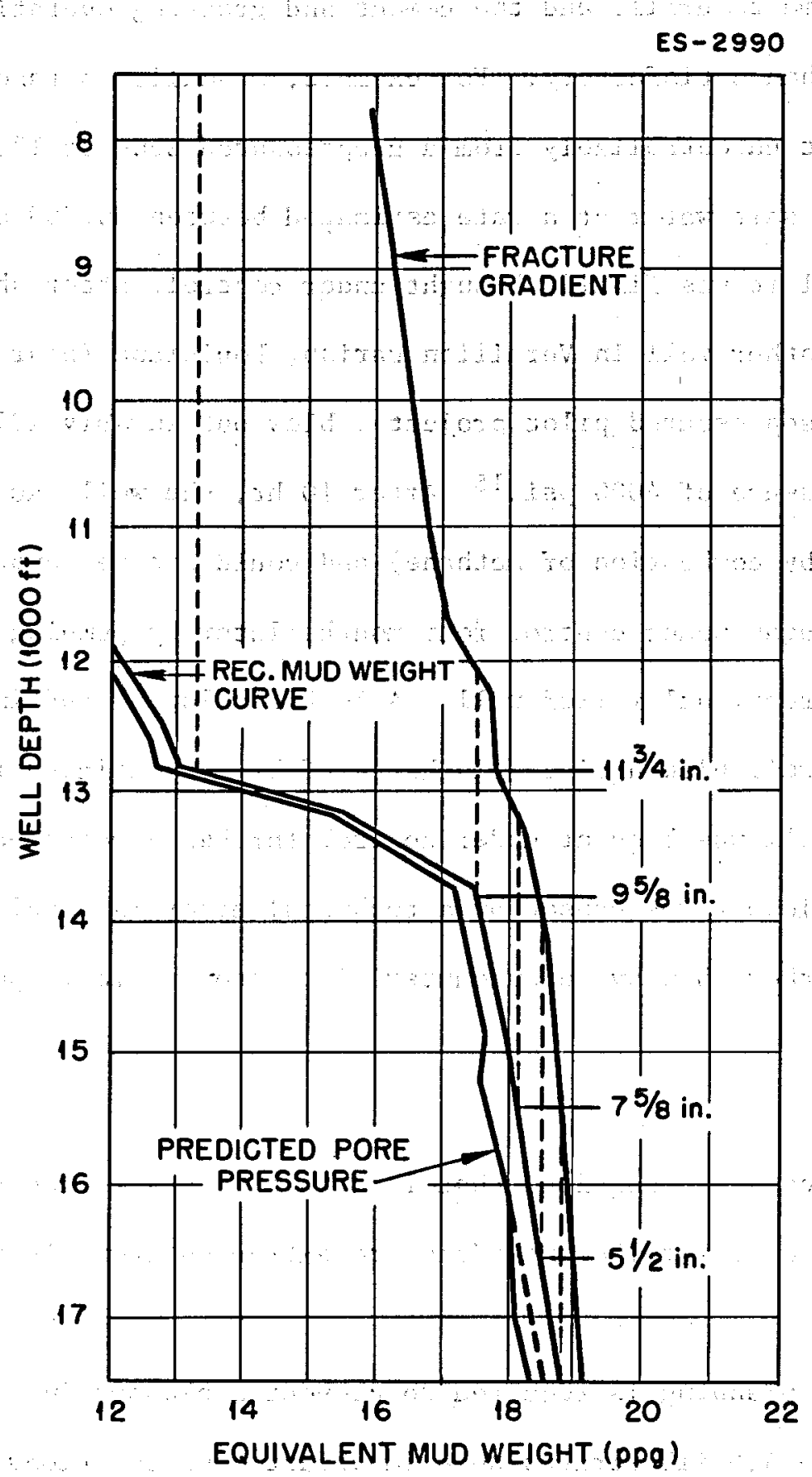

Fig. 4.8. Pressure conditions, Southern Louisiana. Source: E. R. Berman, Geothermal Energy, Noyes Data Corporation, Park Ridge, N.J., 1975. 
lands leased for geothermal exploration and development, adequate blowout preventors must be inspected and maintained, and regular blowout rehearsals must be conducted In accordance with GRO Order 2.27

The weight of the driling mud is determined by the predicted pore pressure as a function of depth. If a high-pressure zone is encountered at an unexpectedly shallow depth, the drilling mud may be too light, and a blowout may occur.

On the other hand, if a casing is set too shallow, the heavy driling mud may drive Itself into a normally pressured sand aquifer below the base of the casing. Consequently, circulation will be lost. It is necessary to set the casing below the deepest normally pressured sand aquifer but above the geopressured zone. This may involve a narrow range of depths in which casings can be set without risking a blowout or lost circulation.

Lost circulation is not as severe a problem as a blowout, but it can nevertheless lead to serlous economic consequences. A second, smallerdiameter casing string must be inserted through the first to seal off the normally pressured sands. Too many successively telescoped stages of caslng sting lead to early abandonment of the well above the objective horizon because the production string diameter would be too small to yield the necessary economic flow rate. 
After the first casing string is successfully set, the weight of the driliing mud must be carefully controlled. If the mud is too light, the danger of blowout exists. A mud that is too heavy may fracture the wall rock below the bottom of the casing. As drilling mud surges into the fractures; a blowout could occur despite the heavy weight. Below about $14,000 \mathrm{ft}$, the weight of the drilling mud must occupy a narrow range between the expected pore pressure and the hydraulic fracture gradient.

As the depth increases, shallower formations within the geopressured zone must be protected from hydraulic fracturing by means of additional smaller-diameter (telescoping) casing strings. With increasing depth, the weight of the drilling mud must increase to keep pace with increasing pore pressure. In the shallower part of the hole, between the end of the last casing string and the drill bit, the weight of the mud may exceed the hydraulic fracture gradient. To protect the wall rock from fracturing, overlapping casing strings are set.

At this time, the driller's judgment again becomes critical. If he cautiously sets too many stages of casing string, the hole becomes too narrow, and It may have to be abandoned before reaching its objective. If the driller sets too few casing strings, the hole may blow out..

Careful selection of the initial hole size and casing diameter is perhaps the most critical factor. If the initial casing size is large enough, the driller will be able to use more casing strings and still 
reach the target depth. Thus; he w111, not be forced to choose between premature abandonment and the risk of $a$ blowout.

According to Berman, 24 withdrawal of the drilling mud in preparation: for bringing the well into production is a critical time, If the casing is weak, it will collapse because there is no internal pressure to counterbalance the pore pressure. Furthermore, Cromling ${ }^{28}$ states that blowout preventors are most 11kely to fall during the last trip out of the hole.

\subsubsection{Ruptured pipelines and cana1s}

Ruptured geothermal pipelines may cause intense but short-duration surface spills. Whereas blowouts and ruptured well casings may be difficult

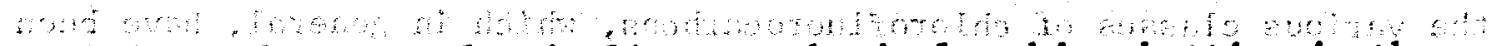
to bring under control, pipelines can be 1solated by shutting in the appropriate wells and, if necessary, closing down the generating plant.

If reinjection proves to be unsatisfactory (Sect. 4.2.4.1), it might be necessary to dispose of waste flulds In estuaries, coastal bays, lagoons,

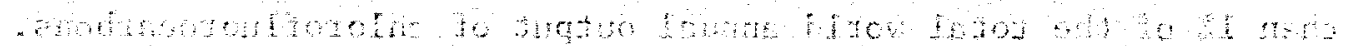
or open sea. Astde from the possibility of chemical and thermal pollution of these disposal areas, leaks might develop in the linings of temporary settling ponds, pipelines, and canals. By using distant disposal sites, the area of environmental impact will be extended over a wide area. 
In a plant using a binary system, the fluid on the turbine side of the heat exchanger may be isobutane or some other volatile material Rupture of an isobutane pipeline can lead to a potentially dangerous flash fire. Risks of fire are similar to those of plants using large amounts of natural gas: Without a heat èxchanger, geothermal steam passes through the turbine, and the danger of fire is greatly reduced; however, highly flamable methane gas is an important by-product of geopressure: production. Although potential lgnition of surrounding vegetation is possible, fires involving binary fluids or methane would be expected to be contained on site. Brush-control practices in areas surrounding the generator plant will reduce the potential for forest and brush fires..

Many other fluids may be used in binary systems. Of particular note are the various classes of chlorofluorocarbons, which in general, have been implicated as potential sources of catalytic agents which may accelerate decomposition of stratospheric ozone. ${ }^{29}, 30$ Release of large amounts of these chemicals is not expected to occur except during accidents. Even under worst-case conditions, the potential release would amount to far less than $1 \%$ of the total world annual output of chlorofluorocarbons. 
- REFERENCES FOR SECTION 4

1. G. K. Underh11I et al., Proc. Ind Geopressured Geothermal Energy Conference. Voltme IV. Surface Technology and Resource Utilizations, University of Texas, Austin, Feb, 23-25, 1976.

2. U.S. Department of the Interlor, Final Environmental statement for the Geothermal Leasing Program, vol. $\mathbf{I}, \mathrm{U} . \mathrm{S}$. Government Printing office, Washington, D.C., 1976.

3. C. W. Kreitler and T. C. Gustavson, "Geothermal Resources of the Texas Gulf Coast - Environmental Concerns Arising from the Production and Disposal of Geothermal Waters, Proc. 2na Geopressured Geothermal Energy Conference. Volume V. Legal, Institutional and Envirommental, University of Texas, Austin, Feb. 23-25, 1976.

4. M. H. Dorfman and R. O. Kehle, Potential Geothermal Resources of Texas, Geo1. Circ. 74-4, Bureau of Economic Geology, University of Texas, Austin, 1974 .

5. P. A. Domenico, Concepts and Models in Ground Water Hydrology, McGraw-HI11, Inc,, New York, 1972 .

6. S. S. Papadopulos, R. H. Wallace, J. B. Wesselman, and

R. E. Taylor, Assessment of Onshore Geopressured Resources in the Northerm Gulf of Mexico Basin, U.S. Geol. Surv. Circ. 726, Reston, Va., 1975 .

7. M. S. Hantush, "Modification of the Theory of Leaky Aquiflers," J. Geophys. Res. 65 (11) (1960).

-8. J." Geertsma, "Land Subsidence above Compacting 011 and Gas Reservoirs," J. Pet. Technol. 25 (1973). 
9. A. Finol and S. M. Faroug Al1, "Numerical Simulation of 011 Production with Simultaneous Ground Subsidence," Soc. Pet. Eng. (1975).

10. E. Herrin, Development of Geothermal Reservoirs from Over-Pressured

-Areas Beneath the Gulf Coastal Plain of Texas. A Feasibility Study of Power Production from Over-Pressured Reservoirs, AP-766 855, Advanced Research Projects Agency, March 1973.

11. P. H. Jones, "Geothermal Resources of the Northern Gulf of Mexico Basin," U.N. Symposium on Development and Utilization of Geothermal Resources, Pisa, Italy, 1970.

12. T. W. Thompson and K. E. Gray, "Rock Mechanics Aspects of Geopressured Geothermal Reservoirs: Subsurface and Surface Behavior," Proc. 2nd Geopressured Geothermal Energy Conference. Volume III, University of Texas, Austin, Feb. 23-25, 1976.

13. R. M. Knapp and 0. F. Isokrar1, "Aspects of Numerical Simulation of Future Performance of Geopressured Geothermal Reservoirs," Proc. 2nd Geopressured Geothermal Energy Conference. Volume III, University of Texas, Austin, Feb. 23-25, 1976.

14. J. T. Christian, "Subsidence of Venice: Predictive Difficulties," Science 185 (1974).

15. E. Herrin and T. Goforth, "Environmental Problems Associated with Power Production from Geopressured Reservoirs,". Proc. First Geopressured Geothermal Energy Conference, M. H. Dorfman and.

R. W. Deller, eds., University of Texas, Austin, 1975.

16. c. W. Kreitler, Lineations and Faults, Texas Coastal Zone, Bureau of Economic Geology, University of Texas, Austin, In press. 
17. Energy Research and Development Administration, An Environmental Assessment of Proposed Geothermal Well Testing in the Tigre Lagoon Oil Field, Vermilion Parish, Louisiana, Division of Geothermal Energy, Washington, D.C., 1976.

18. G. W. Schmidt, "Interstitial Water Composition and Geochemistry of Deep Gulf Coast Shales and Sandstones,"Am. Assoc. Pet. Geol. 57(2) (1973).

19. K. Magara, "Compaction, Ion Filtration and Osmosis in Shale and their Significance in Primary Migration," Am. Assoc. Pet. Geol. $58(2)(1974)$

20. M. T. Halbouty, Salt Domes - Gulf Region, United States and Mexico, Gulf Publishing Company, Houston, Tex., 1967.

21. Anonymous, "Brine Disposal," Proc. 2nd Geopressured Geothermal Energy Conference. Volume IV. Surface Technology and Resource Utilization, University of Texas, Austin, Feb. 23-25, 1976.

22. L. E. Garrison, "Geothermal Steam in the Geysers - Clear Lake Region, Californla," Geol. Soc. Am. Bulz. 83 (1972).

23. R. A. Carlson, P. H. Powe11, and G. K. Underhill, "Industrial Utilization of Geopressured Geothermal Energy," Proc. 2nd Geopressured Geothermal Energy Conference. Volume IV. Surface Technology and Resource Utilization, University of Texas, Austin, Feb. 23-25, 1976.

24. D. M. Evans, "Man-Made Earthquakes in Denver," GeoTimes 10(9) (1966).

25. S. Kaufman, as quoted in B. Myers, R. Nelson, J. Howard, and R. Austin, Some Elements of the Northern Gulf of Mexico Basin Geopressure Energy Resource, Lawrence Livermore Laboratory, University of California at Livermore, 1973. 
26. E. R. Berman, Geothermal Energy, Noyes Data Corporation, Park RIdge, N.J., 1975 .

27. U.S. Geological Survey, Geothermal Resources Operational Orders. GRO Order 2. Drilling, Completion, and Spacing of Geothermal Wells, Menlo Park, Callf., January 1976.

28. J. Cromling, "How Geothermal Wells are Drilled and Completed," World Oil 177: 42-45 (1973).

29. A. L. Hammond and T. H. Maugh, "Stratospheric Pollution: Multiple Threats to Earth's Ozone," Science 186: 335-38 (1974).

30. N. I. Sox, Dangerous Properties of Industrial Materials, Rheinhold Publishing Company, New York, 1957. 


\section{ECONOMIC AND SOCIAL EFFECTS}

The effects of the development and operation of geopressured geothermal energy systems may include changes in population size, local economics, avallability of housing and services, employment level, aesthetics, and other aspects of the general quality of life. The effects will be different for the different uses of the resource.

The magnitude of economic and social effects depends on existing conditions Including population density dispersion, age structure, education and degree of training, avallability of services; and existing employment levels. Population density is an Lmportant and readily available social Indicator. Southern Loulsiana (except for the coastal marshlands) and the eastern coast of Texas generally have high to moderate population densities and a correspondingly high avallability. of labor and economic resources. Population levels and standards of living generally decline southward. 1

\subsection{EFFECTS OF CONSTRUCTION ACTIVITIES}

The soclal effects of resource development will not be significant until fleld development and plant construction begin. Even then, the effects on population and economics may be large only in sparsely populated areas. Studies of Sonoma County, Calffornia (The Geysers fleld), Imperial County, California (East Mesa and Niland test sites), and

- Sandoval County, New Mexico (exploration and drililng), failed to demonstrate any large-scale soctoeconomic effects of geothermal energy development. 1 
The peak local labor force profected by the Pacific Gas and Electric Company for the construction of Geysers Unit 13 is 80 people. ${ }^{2}$ This Increase in employment w11l have greater effect in sparsely populated areas. Trained drilling crews are readily avallable in the entire region because of the large oll and gas Industry.

Where construction occurs in developed areas, wages and money spent on materials and services could make a significant local economic contribution. The Pacific Gas and Electric Company estimated that construction of Geysers Unit 13 will make a peak contribution to the local economy of over $\$ 1$ million per quarter. 2 Construction in sparsely developed areas will require the importation of materials and labor from a larger area, and, therefore, the economic benefits will be more dispersed. The percentage increase in local economic activity may, however, be greater in these areas.

Construction of facilities for nonelectrical use will have highly var1able effects. Space heating for existing structures w11l require a relativeIy small investment and work force. Social effects will increase with the amount of construction required for the end use. Because an Industrial project will generally be larger than an electrical generating station using the same resource, it w111 have a greater Impact.

The aesthetic effects of construction will be both visual and auditory. Construction noise will be similar to that of any construction project except for the release of steam from wells and 1ines. Visual impacts 
may occur from constructionn In a previously unindustrialized area . Generally, the seriousness of aesthetic impacts will be related to the number of people exposed and the perceived desirability of the project.

\subsection{EFFECTS OF OPERATION}

An operating geothermal electric plant requires a small operating crew and will thus have a small effect on population, housing, or services. Because the generating units operate automatically; the entire array of 12 units at The Geysers is run by a 45 -man crew. 2 Maintenance or the drilling of new wells will result in a temporary increase in population, similar to the increase that occurs during construction. Because of its value and low associated demand for services, a geothermal electric plant will be a valuable addition to a local tax base. Although such plants will be a local source of relatively inexpensive electrical energy, the energy may not be cheap or plentiful enough to attract industry.

The existing nonelectrical uses of hydrothermal energy (e.g., space heating and greenhouses) have small social effects. However, if this resource proves to be an attractive source of Industrial process heat, the social effects may be quite large. Although industrial development may disrupt social structures and strain services, opportunities for employment of unskilled or semiskilled workers will be particularly welcome in southern Texas. 
REFERENCES FOR SECTION 5

1. K. Letlow, S. C. Lopreato, M. Meriweather, P. Ramsey, and J. K. Williamson, "The Development of Geothermal Energy In the Gulf Coast: Socio-Economic, Demographic, and Political Considerations," Proc. Second Geopressured Geotherm. Energy Conf., vol. 5, Center for Energy Studies, University of Texas, Austin, 1976.

2. Pacific Gas and Electric Company, Geysers Unit No. 13 and As80ciated Transmission Lines, Draft EIR, Callfornia Public Ut1lities Commission Application No. 54750. 


\section{MONITORING}

The extent and deta1l of monftoring programs w11l depend largely on the size and character of the proposed activities, for example, electrical generation vs process heat. The purpose of preoperational monitoring programs is to establish baseline data on air and water quality, land use, terrestrial and aquatic ecology, socioeconomics, and geology so that effects of the proposed operation can be separated from existing conditions. Also, specific problems associated with these areas can be solved by design or site modifications prior to fleld development and construction. Preoperational monitoring Includes all activities up to the point of using the resource. The preoperational sampling program Is extremely important because it sets the accuracy and significance of all later sampling.

Operational monttoring should continue programs developed during preoperational móntoring. As more Information becomes avallable; those programs that show little change because of the existence of the plants can be elther deleted or cultivated.

The purpose of monitoring is: to ensure early warning of malfunctions and mishaps and to substantiate or deny potential sources of environmental Impact. Monitoring may be conducted to document environmental effects, or absence thereof, related to drilling, facility construction, and production operations of geothermal resources. Impacts amenable to monitoring include noise, air quality, water quality, radioactivity, erosion, fish and wildlife, seismicity, and subsidence. 
Monitoring may be continuous or it may take place at specified intervals or during critical phases of development. The extent and frequency of monitoring will depend on the nature of the environmental effect being monitored, variablitty of geology, terrain, climate, blology, and other factors.:

Monitoring guidelines for leases on Federal land have been established by the U.S. Department of the Interfor. I. The guidelines are (1) monitoring of short-term localized impacts (e.g., noise) that are readily identified and assoclated with specific activities on an individual lease and (2) monitoring of impacts that cannot be readily identified with an individual lease (e.g., water quality) or are regional in scope (subsidence and selsmicity).

It is not always certain where a particular monitoring activity might be most effective. For example, mercury vapor is sometimes vented with other noncondensable gases. It is readily washed from the atmosphere by rain. It is then absorbed by clay minerals and hydrous iron and manganese oxides in the upper few inches of soil. ${ }^{1}$ In a sulfide-rich reducing environment, compounds of mercury sulfide are precipitated. Also, organic solvents form complex lons with mercury, notably methy1 mercury. In this form, it is ingested by fish and other aquatic animals. A monitoring program considers both the total release and the fate of effluents, particularly relative to known sensitive systems. 
The extent and nature of monitoring programs must be determined for each project, and the evaluation of reglonal monitoring is the objective of some ERDA programs now In progress. The activities described herein are therefore typical and will not necessarily be all-inclusive or apply to all projects equally.

\subsection{AIR}

Afr monitoring Includes sampling stations that monitor hydrogen sulfide, sulfates, and particulates. Meterological data (precipitation, humfity, temperature, etc.) can be collected by onsite weather stations. Information on Inversion frequency and long-term climatic conditions can be retrleved from weather tapes of the closest national weather station. These data will be used to calculate dispersion of hydrogen sulfide and other pollutants to predict and dellneate areas of impact.

\subsection{LAND}

Vegetation in the area can be surveyed and mapped, characterizing the various habitats. Vegetation can be sampled and analyzed for heavy metals and all toxins that may be released during field development and utillzation. Important wildiffe can be enumerated. "Important" here connotes specles important comerclally or recreatlonally, species that are Important components of ecosystems, or species that are rare or unique. Sampling can also Include time spans that account for seasonal variation and migration. Soll from specific areas in and around the 
site can be analyzed for heavy metals and other compounds that may be released. These data will be used to relate impact to the surrounding plant and animal species and to set a baseline to follow chemical accumulation in the surrounding environs.

\subsection{WATER}

Surface water quality in the vicinity and all waters that have the potential to recelve runoff from the development and utilization phases can be monftored... Water quality includes monitoring for temperature, salinity, $\mathrm{pH}$, dissolved solids, turbldity, blological oxygen demand (BOD), chemical oxygen demand (COD), total organics, heavy metals, sulfates, and other compounds that may be released. Blological sampling (i.e., samples of fish invertebrates and aquatic macrophytes) can be undertaken to characterize ecology, trophic relationships, spawning, and production. These data will be used to relate before-and-after effects on aquatic systems.

\subsection{NOISE}

Noise can be monitored periodically at various points in and around the site and at some distance away to establish background noise levels. Potential topographlcal features that may contain nolse can be noted.

\subsection{GEOLOGY}

Geological description and characterization of the site will be undertaken as part of the early evaluation of the site. However, fault 


\section{6-5}

activation and subsidence can be monitored throughout all stages of development and operation. Passive seismic studies will provide a continual record of micro- and macro-earthquake activity and w111 display any significant increases possibly caused by geothermal operations. In addition, baseline studies can be undertaken to establish ground surface criteria to document subsidence. Both subsidence and seismic monitoring will require sufficlent baseline data prior to development to determine whether any of the documented geologic effects are naturally occurring or Induced by geothermal operations.

REFERENCES FOR SECTION_6

1. U.S. Department of the Interior, Final Envirormental Statement for the Geothermal Leasing Program, Vol. I, Washington, D.C., 1973. 


\section{INSTITUTİONAL CONSIDERATIONS :}

The interaction of the geopressure subprogram activities with local,

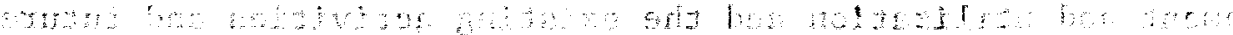
state, regional, and Federal plans and regulations requires evaluation on a project-by-project basis as well as on a programmatic basis. Institutional considerations will, therefore, be evaluated for each project requiring an environmental assessment and as a part of the geopressure subprogram in general.

The principal institutional consideration is that neither of the two states in which the geopressure subprogram activities are planned has defined the geopressured resource, established its legal ownership, nor prepared legislation for taxation or regulation of the resource. ERDA will comply with existing regulations as they are applied to the geopressured resource and w11l offer assistance in establishing effective controls over the development of the resource. In addition, ERDA will establish the compatibility of its projects with current and longrange plans for the surrounding areas.

Other institutional factors to be considered are the lack of market information for the resource, the abundance of gas and oil in the geographical regions of the geopressured resource, and the socioeconomic changes associated with industrial development in previously undeveloped areas. The impact of the entire geopressure subprogram Includes the effects of commercial and industrial development on these institutional factors that may result in the future. One goal of the geopressure 


\section{7-2}

subprogram is to support development of both the technology and the methodology for minimizing conflicts between geopressured resource development and utilization and the existing activities and future plans of the regions affected. 
The proposed actions consist of the programmatic subprogram of the Division of Geothermal Energy (DGE) for encouraging the development of geopressured geothermal resources consistent with Project Independence

In goals: Because this environmental assessment is limited to a programmatic overview, specific project alternatives cannot be addressed in detall but vit must be considered when an environmental assessment is required for a specific project. Therefore, the alternatives addressed herein are the

Programmatic alternatives of (1) no action, (2) delay support of the orcl development of geothermal resources; or (3) delay support of the development of geopressured resources.

\subsection{NO ACTION OR DELAY SUPPORT OF GEOTHERMAL PROGRAM}

As discussed in Sect, 1 , the Geothermal Research, Development, and Demonstration Act of 1974 requires that ERDA support a program for encouraging the timely development of geothermal energy. Under this mandate, the alternative of not pursuing the proposed actions is not open to ERDA. The Act also Includes the requirement to support the development of geothermal energy. in an environmentally sound manner. This goal has resulted in a selection of projects by ERDA that emphasize environmental effects as well as technological developments. Thus, the - program has built into it the mechanism for changing direction or for stopping specific projects before irreversible impacts occur or unpredicted environmental impacts become significant. The current technology for 
using geothermal energy is such that no significant increase in development rate is 11kely without added incentives for the developers. If these Incentives are provided soon, the anticipated growth rate of installed geothermal' power capacity for the year 1990 is projected to be about three times as great as the growth rate for that year without incentives (Sect. 1). Each year of delay In supporting geothermal energy development will likely result in a corresponding delay in the date when measurable results can be expected from the support. To meet the anticipated inability of this country to supply its energy needs in the year 1985 (Sect. 1), the need for Immediate support of development of environmentally sound energy sources is evident, and any delays are Inconsistent with Project Independence goals.

\subsection{NO ACTION OR DELAY SUPPORT OF GEOPRESSURED RESOURCES}

The geopressured resources are the geothermal resources for which resource data and operating experfence are needed in order to encourage development. Thus, early support of geopressured resource development has been emphasized by ERDA to provide this information to the industry. On this basis, lack of support for geopressured resource development would only serve to delay the overall geothermal program; likewise, delayed support of geopressured resource development in favor of increased or earlier support of hydrothermal or hot dry rock resources would also have the net effect of delaying the overall geothermal program. It should be pointed out, however, that there is ERDA-DGE support for the 
development of all forms of geothermal energy in the ERDA geothermal program at levels commensurate with the current technology associated with developing these resources.

The present technology for use of geothermal resources is predominantly for vapor-dominated reservoirs. Present surveys of known geothermal resources indicate that the amount of vapor-dominated energy is Iimited and that a potentially significant amount of energy is contained in geopressured reservolrs. Without significant environmental and technological advances in knowledge, however, it is unlikely that there will be a substantial amount of energy tapped from the geopressured reservolrs. 